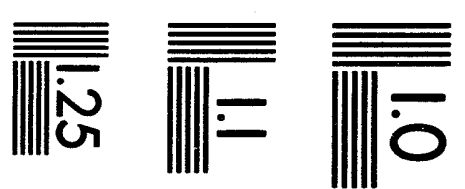

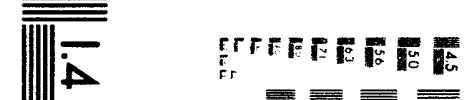

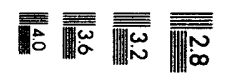

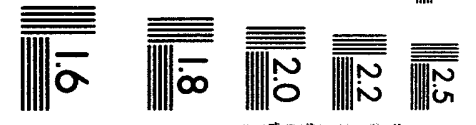



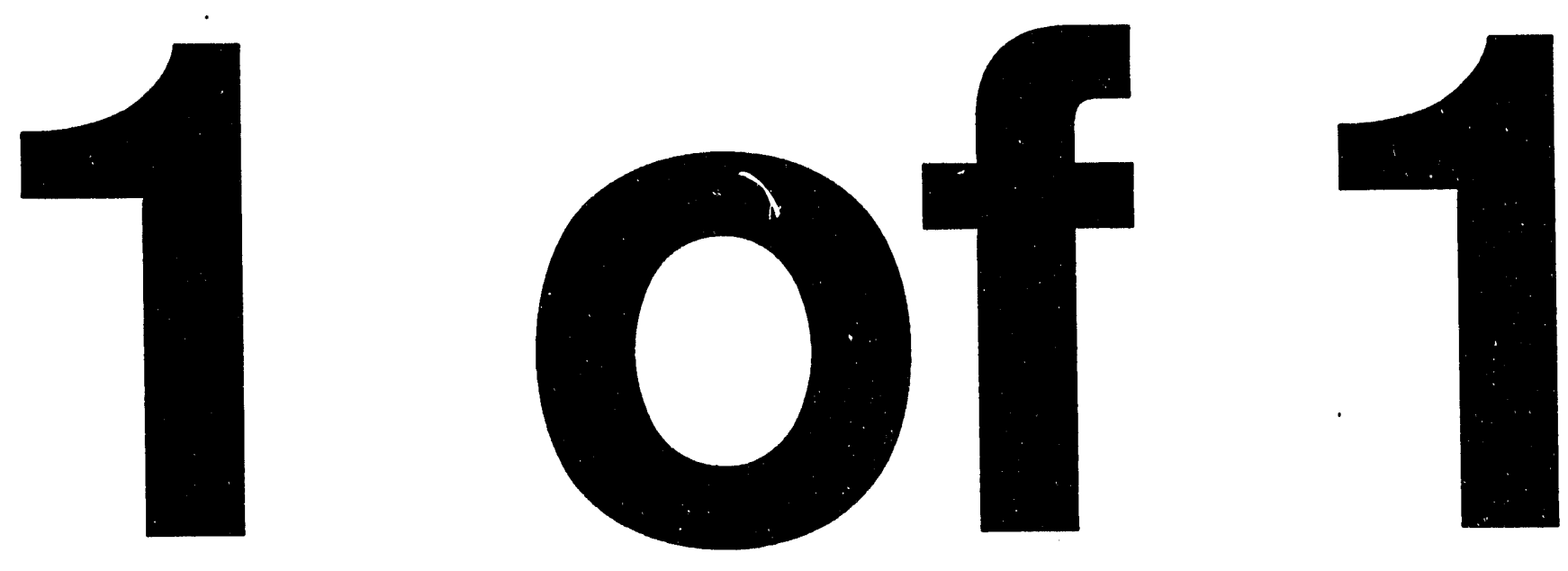
Energy Systems Environmental Restoration Program ORNL Decontamination and Decommissioning Program

\title{
Decontamination Project for Cell G of the Metal Recovery Facility at Oak Ridge National Laboratory, Oak Ridge, Tennessee
}

\author{
G. J. Mandry \\ R. W. Grisham
}

Date Issued-February 1994

Prepared by

Allied Technology Group, Inc.,

Freemont, California

Prepared for

U.S. Department of Energy

Office of Environmental Restoration and Waste Management under budget and reporting code EW 20

OAK RIDGE NATIONAL LABORATORY

Oak Ridge, Tennessee 37831-6285

managed by

MARTIN MARIETTA ENERGY SYSTEMS, INC.

for the

U.S. DEPARTMENT OF ENERGY

under contract DE-AC05-84OR21400

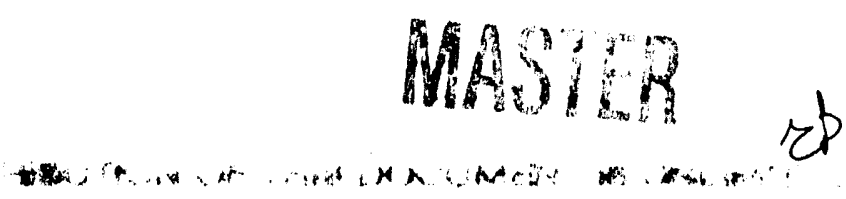




\section{Author Affiliations}

G. J. Mandry is a member of the Waste Management and Remedial Action Division at Oak Ridge National Laboratory, Martin Marietta Energy Systems, Inc. R. W. Grisham is employed by Allied Technology Group of Freemont, California. 


\section{CONTENTS}

ABBREVIATIONS $\ldots \ldots \ldots \ldots \ldots \ldots \ldots \ldots \ldots \ldots \ldots \ldots \ldots \ldots \ldots \ldots$

EXECUTTVE SUMMARY $\ldots \ldots \ldots \ldots \ldots \ldots \ldots \ldots \ldots \ldots \ldots \ldots \ldots \ldots \ldots$ vii

1. INTRODUCTION $\ldots \ldots \ldots \ldots \ldots \ldots \ldots \ldots \ldots \ldots \ldots \ldots \ldots \ldots \ldots \ldots$

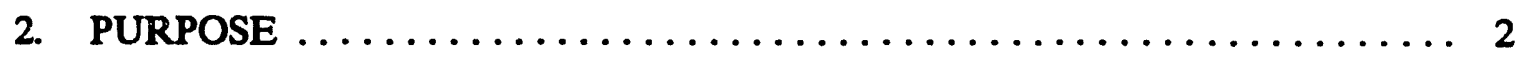

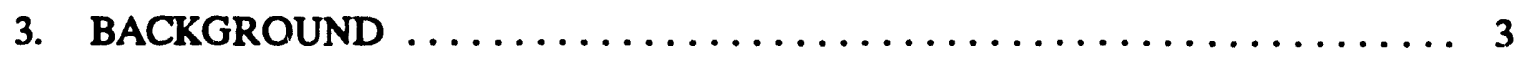

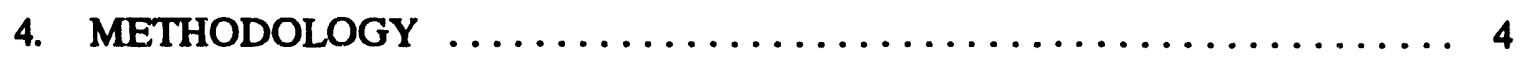

5. RESULTS AND DISCUSSION $\ldots \ldots \ldots \ldots \ldots \ldots \ldots \ldots \ldots \ldots \ldots$

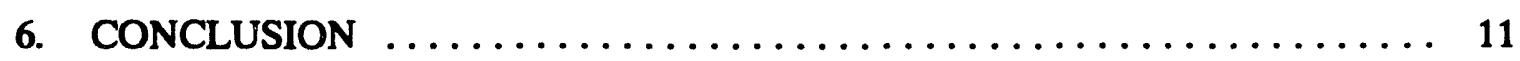

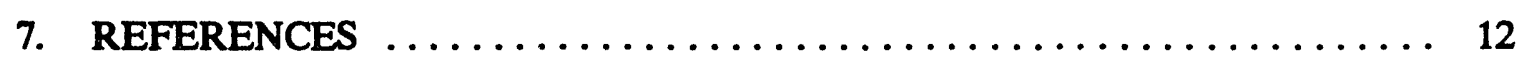

Appendix A: VIEWS OF THE METAL RECOVERY FACILITY $\ldots \ldots \ldots \ldots$ A-1

Appendix B: REPORTS $\ldots \ldots \ldots \ldots \ldots \ldots \ldots \ldots \ldots \ldots \ldots \ldots \ldots \ldots \ldots \ldots \ldots \ldots$

Appendix C: LESSONS LEARNED $\ldots \ldots \ldots \ldots \ldots \ldots \ldots \ldots \ldots \ldots \ldots \ldots \ldots \ldots \ldots \ldots$

Appendix D: COST AND SCHEDULE SUMMARY $\ldots \ldots \ldots \ldots \ldots \ldots \ldots$ D-1 


\section{ABBREVIATIONS}

$\begin{array}{ll}\text { ATG } & \text { Allied Technology Group } \\ \text { CRZ } & \text { contamination reduction zone } \\ \text { decontamination and decommissioning } \\ \text { D\&D } & \text { derived air concentration } \\ \text { DAC } & \text { U.S. Department of Energy } \\ \text { DOE } & \text { Martin Marietta Energy Systems, Inc. } \\ \text { Energy Systems } & \text { high-efficiency particulate air } \\ \text { HEPA } & \text { Health Physics } \\ \text { HP } & \text { Metal Recovery Facility } \\ \text { MRF } & \text { Oak Ridge National Laboratory } \\ \text { ORNL } & \text { personnel protective equipment } \\ \text { PPE } & \text { Radiation Protection } \\ \text { RP } & \text { toxicity characteristic leaching procedure } \\ \text { TCLP } & \end{array}$




\section{EXECUTIVE SUMMARY}

The goal of the decontamination effort in Cell $G$ at the Metal Recovery Facility, Building 3505, located at the Oak Ridge National Laboratory, was two-fold: to determine the effectiveness of the dry decontamination technique employed and to provide data required to assess whether additional decontamination using this method would be beneficial in the eventual decommissioning of the facility. Allied Technology Group (ATG) was contracted to remove a portion of the concrete surface in Cell $\mathrm{G}$ by a technique known as scabbling. Some metallic cell components were also scabbled to remove paint and other surface debris. Generally, the scabbling operation was a success. Levels of contamination were greatly reduced. The depth of contaminant penetration into the concrete surfaces of certain areas was much greater than had been anticipated, necessitating the removal of additional concrete and extending ATG's period of performance. Scabbling and other related techniques will be extremely useful in the decontamination and decommissioning of other nuclear facilities with similar radiological profiles. 


\section{INTRODUCTION}

The Metal Recovery Facility (MRF) at the Oak Ridge National Laboratory (ORNL) is a small-scale production reprocessing plant that was operated from 1951 to 1960 . The facility consists of Building 3505 and an adjacent dissolver room, dissolver pit, and below-grade canal. Implementing a modified Purex process, operators of the MRF recovered uranium, plutonium, neptunium, and americium from a variety of feed materials. The reprocessing operations were conducted in a bank of seven concrete cells, designated Cells A through $G$. Cell $G$, the subject of this report, is located at the east end of Building 3505 (Appendix A, Fig. A.1).

In 1960, Building 3505 was judged inadequate to provide containment for processing large quantities of radioactive materials. Roof hatches opened directly to the environment and cell roof construction was deemed too light. Operational restrictions placed on the facility forced it into a shut-down mode, and the facility was abandoned in 1960. Before facility D\&D could occur, upgrading and reconditioning of structures and services were necessary. Installing an add-on high-efficiency particulate air (HEPA) filtered cell ventilation system was the major construction task performed to ready the structure for decontamination. These modifications were performed in the early 1980 s.

After building preparations sufficient to allow decontamination operations had been conducted, equipment removal efforts began. Equipment inside Cells $A$ through $G$ was dismantled and appropriately packaged for disposal. All remaining equipment supports and services were stripped to provide clean surfaces for decontamination activities.

Cell $\mathrm{G}$ is a structure made of concrete blocks grouted together. The cell is $8 \times 9 \times 17 \mathrm{ft}$ high and has a floor drain located in the center of a 6-in.-deep stainless steel floor pan. In the north wall of the cell is a 2 - $\mathrm{ft} \times 2$ - $\mathrm{ft} \times 8$-in.-thick steel access hatch, the bottom of which is approximately $3 \mathrm{ft}, 6 \mathrm{in}$. from the floor. A metal hatch with structural support members constitutes the roof of the cell, and an 8 in. by 4 in. stainless steel panel is located in the southeast corner of the cell. A 2-in.-thick door on the south side of the cell is the remaining access to Cell G. 


\section{PURPOSE}

Martin Marietta Energy Systems, Inc. (Energy Systems), contracted with ATG to decontaminate the MRF. The specific purpose of the Cell $\mathrm{G}$ decontamination project is to evaluate the effectiveness of commercially available dry decontamination techniques and to factor the results of this decontamination into the D\&D design. Because of extensive radiological contamination, Cell $\mathrm{G}$ was chosen first for decontamination.

ATG provided the following plan for cell decontamination: to decontaminate Cell G, $1 / 4$ in. of concrete will be removed from the surface of the concrete block structure. The method chosen for removal will generate little or no liquid radioactive waste. Dry decontamination techniques will also be used to decontaminate the stainless steel floor pan and the overhead structural members. At the end of the decontamination effort, the surface areas of the cell will be painted or sealed to prevent recontamination of clean surfaces. 


\section{BACKGROUND}

Extremely high alpha contamination levels existed on, and were entrained in, the concrete surfaces of Cell G. Preliminary survey data (Appendix B, Report B.1) supplied by Energy Systems indicated that these levels were $>1.0 \times 10^{6} \mathrm{dpm}$ per $100 \mathrm{~cm}^{2}$. Beta-gamma levels in Cell $\mathrm{G}$ were $<2 \mathrm{mrem} / \mathrm{h}$. Thus, the primary concern for the decontamination task was alpha airborne contamination concentrations and not the penetrating beta-gamma radiation. Table 1 lists the alpha contamination levels in Cell $\mathrm{G}$ before decontamination.

Table 1. Cell $\mathbf{G}$ average alpha contamination

\begin{tabular}{cccc}
\hline Area & $\begin{array}{c}\text { 0-6 ft } \\
\left(\mathrm{dpm} / 100 \mathrm{~cm}^{2}\right)\end{array}$ & $\begin{array}{c}6-17 \mathrm{ft} \\
\left(\mathrm{dpm} / 100 \mathrm{~cm}^{2}\right)\end{array}$ & $\begin{array}{c}\text { Hot spot } \\
\left(\mathrm{dpm} / 100 \mathrm{~cm}^{2}\right)\end{array}$ \\
\hline North wall & 461,000 & 45,000 & $>2,500,00$ at $4 \mathrm{ft}$ \\
East wall & 110,000 & 40,000 & $800,00 \mathrm{SE}$ at $7 \mathrm{ft}$ \\
South wall & 87,000 & 15,000 & $850,000 \mathrm{SW}$ corner \\
West wall & 69,000 & 16,000 & $500,000 \mathrm{SW}$ corner \\
\hline
\end{tabular}

The primary radioisotope of concern in Cell G is ${ }^{239} \mathrm{Pu}$. Core bores taken from Cell G indicated that most of the contamination (up to $95 \%$ of the activity) resided in the first $1 / 4$ in. of concrete (Ref. 1). The overall extent of contaminant migration into the block walls could not be assessed with certainty before decontamination efforts began. The main emphasis of the project was to remove the top $1 / 4$ in. of concrete from the cell walls. 


\section{METHODOLOGY}

To ensure proper planning and success of the decontamination project, ATG used detailed characterization data and the operational history of Cell G. Use of this information, provided by Energy Systems, led to a viable approach which would result in successful completion of the contracted task.

Characterization surveys indicated high levels of alpha contamination throughout the cell (Table 1). Thus, controlling internal exposure to workers and implementing contamination controls to protect other areas of the building and the environment were primary concerns in the decontamination effort. Penetrating radiation associated with beta-gamma was $<2 \mathrm{mrem} / \mathrm{h}$ in the general area of the cell, reducing exposure concerns associated with the decontamination effort.

A HEPA-filtered cell ventilation system was installed in Building 3505, so that negative pressure could be maintained in all cells during decontamination efforts, assuring that airborne contamination would not flow to areas outside the cell. The HEPA system had an estimated flow of $10,000 \mathrm{ft}^{3} / \mathrm{min}$. To achieve maximum negative pressure, all cell penetrations were sealed with foam sealant. For backup ventilation, a portable $1000-\mathrm{ft}^{3} / \mathrm{min}$ HEPA-filtered unit was available.

To control the spread of contamination from the cell to adjacent areas of the building, a double tent system was used and contamination reduction zones (CRZs) were established. The first CRZ was connected to the regulated area of the makeup room at the point of egress. The second CRZ was connected to the cell itself, where a high-contamination laydown area was set in place for exiting the cell. This CRZ also served as the staging area for equipment used for cell decontamination. A double-door system between the two CRZ areas provided another precautionary measure for controlling the spread of contamination. Step-off pads were strategically placed to assure that contamination would be confined to these areas (Appendix A, Fig. A.1). ATG committed to maintaining contamination levels of $5000 \mathrm{dpm}$ per $100 \mathrm{~cm}^{2}$ beta-gamma and $3000 \mathrm{dpm}$ per $100 \mathrm{~cm}^{2}$ alpha in CRZ 1 and 10,000 dpm per $100 \mathrm{~cm}^{2}$ beta-gamma and $5000 \mathrm{dpm}$ per $100 \mathrm{~cm}^{2}$ alpha in CRZ 2.

A frisking station for personnel monitoring was set up at the point of final egress, and a PCM-1B whole body monitor was placed in the former control room to serve as a final contamination monitoring measure before personnel exited the regulated area (Appendix $A$, Fig. A.1).

A supplied air pressure demand system provided respiratory protection for decontamination technicians. This system gave technicians the highest protection factor, maximum comfort under the working conditions at hand, and excellent mobility. Energy Systems Radiation Protection (RP) established a protection factor of 1000 .

To reduce the levels of airborne contamination and its spread to undesirable areas, a method used throughout the nuclear industry was added to the decontamination plan. A nontoxic strippable paint was applied to the walls of the cell to seal loose contamination. In many ways, this step alleviated concerns that had surrounded the cell decontamination effort: (1) airborne radioactive material was reduced, (2) hands-on decontamination effort was not required (this would have created liquid radioactive waste), (3) less radioactive waste was 
generated because use of decontamination materials was minimized, and (4) physical labor was reduced because contamination was confined.

The equipment used to decontaminate Cell $G$ was a system designed by Pentek, Inc. This Pentek system consists of a Vac-Pac unit comprising three parts: vacuum system, roughing filter system and HEPA filters, and hand-held scabble gun. The scabble gun, called the Corner Cutter, has 28 case-hardened needles surrounded by a tube that is connected to a 2-in.-diam vacuum hose. This adjustable tube is positioned within approximately $1 / 8 \mathrm{in}$. of the medium to be scabbled. The vacuum system pulls in the scabbled medium from the scabble gun through the vacuum hose of desired length. The filter system, which is mounted on a hydraulic lift, prevents the scabbled medium from escaping to the environment.

The Vac-Pac unit is equipped with a level indicator light which informs the operator when the drum is full. When the containment drum is full, the operator switches the Vac-Pac unit to the changeout mode. The filter system is hydraulically raised to enable the operator to insert a cardboard disk, sealing the roughing filter by vacuum and enabling the operator to place a lid on the full drum and prepare it for disposal. The full drum is removed, and an empty drum is set into place. The operator then lowers the Vac-Pac unit to the empty drum and switches the unit back to the run mode. The cardboard disk drops to the bottom of the fresh drum, making unnecessary any handling of contaminated media and equipment.

Site mobilization began January 14, 1993. Mobilization included setting up a compressor, sleeving airline hoses, staging Vac-Pac equipment for training, demonstrating the task to be done, and stocking personnel protective equipment (PPE) and supplies.

Training on Vac-Pac unit use was conducted on January 21 and 22, 1993. The system was demonstrated to members of the readiness review committee, Energy Systems managers, RP personnel, and the U.S. Department of Energy (DOE). As the actual decontamination project began, project personnel attended job briefings each morning to discuss the daily work plans and schedule and to discuss accomplishments of the previous work day, including any problems that had been encountered.

Scaffolding was staged January 27, 1993. The initial steps were to complete a comprehensive survey of the cell and to prepare the cell ceiling for scabbling. A highly contaminated ladder, light, and several tools had been left in the cell after previous equipment removal activities. If these items were not removed from the cell, contamination control would be difficult. The items were bagged inside the cell and then rebagged as they were removed. Then followed a hands-on decontamination of the ceiling, a predecontamination survey of the cell, and the application of strippable paint to the cell walls and floor. (See Appendix B, Reports B.2, B.3, and B.4 for pre- and post-painting radiological survey results.)

The scaffolding was then decontaminated to further enhance contamination control efforts. A foam sealant was injected into cell penetrations to ensure that negative pressure in the cell would be maximized and to prevent the potential contamination of adjacent areas.

Airborne concentrations in Cell $\mathrm{G}$ were elevated during ceiling decontamination and cell painting. The derived air concentration (DAC) for plutonium is $2.0 \times 10^{-12} \mu \mathrm{Ci} / \mathrm{cm}^{3}$ (Ref. 2). The concentration during ceiling decontamination and cell painting was $4.12 \times 10^{-10} \mu \mathrm{Ci} / \mathrm{cm}^{3}$. This concentration equates to a DAC fraction of 206. Using an exposure time of $2 \mathrm{~h}$ and a 
protection factor of 1000 , the total resultant DAC hours equaled 0.412 of DAC or 1.03 mrem total exposure to the workers. DAC formulas follow:

$$
\begin{gathered}
\text { DAC fraction }=\frac{\text { concentration }}{\mathrm{DAC}} \\
\text { DAC hours }=\frac{\mathrm{DAC} \text { fraction } \times \text { hours exposed }}{\text { protection factor }} \\
\text { dose }(\mathrm{mrem})=2.5 \times \text { DAC hours }
\end{gathered}
$$

The DAC assigned to the crew for the duration of the Cell $\mathrm{G}$ decontamination project was 11.24 DAC-hours. This amount equates to $28 \mathrm{mrem}$ total exposure, an average of 4.66 mrem per crew member for the decontamination project.

Scabbling began on the ceiling area of Cell G on February 5, 1993. When crew members discovered that the ceiling area was structurally unstable, they aborted use of the scabble gun. Heavy rust areas in the hatch had caused thinning of the metal to the extent that holes were visible. On February 5, 1993, a decision was made to complete the ceiling decontamination by hands-on decontamination and to paint the ceiling. This decision was made because contamination levels in the ceiling were low and structural failure during scabbling was possible (Appendix B, Report B.5).

Cell wall scabbling began February 8, 1993. The control of airborne and loose contamination was the main concern involved in the decontamination process. To keep these contamination levels to a minimum during the decontamination efforts, crew members implemented the following strategy: they (1) removed the strippable paint from one block; (2) scabbled the exposed surface, which was composed of loose contamination; and then (3) removed $1 / 4$ in. of concrete from this block before proceeding to the next. This method was extremely effective for the duration of the project. Contamination levels were kept to a minimum inside the cell as well as in the CRZs (Appendix B, Reports B.6 and B.7).

Scabbling was accomplished at an average rate of $65 \mathrm{ft}^{2} /$ week. Each day began with a 30-min briefing, followed by $45 \mathrm{~min}$ for PPE preparation. Three technicians worked $2 \mathrm{hr}$ per entry, and there were generally two entries per day. The third technician, stationed outside Cell G, was accountable for Vac-Pac unit operation and was designated site contact for the two technicians scabbling, should an emergency situation develop.

The contamination levels increased as scabbling progressed from the top of the cell down (Appendix B, Report B.8). At the 7-ft elevation from the floor, contamination levels increased as shown in Table 1 . These areas of the cell were where most of the equipment used in the recovery process had been located. To ensure that there was no increase in airborne radioactivity concentrations, the portable $1000-\mathrm{ft}^{3}$ HEPA-filtered unit was put into operation. On March 22, 1993, the airborne concentrations increased during scabbling next to the floor pan. Migration of contamination down the walls from leaks or spills from process equipment and the 1-in.-wide lip on the floor pan might explain the increased contamination levels and the rise in airborne radioactivity during scabbling operations.

When the technicians finished scabbling the north and east walls, a direct frisk was initiated. At this point in the project, it was discovered that alpha contamination had 
penetrated further than 1/4 in. into the concrete block in these areas (Appendix B, Report B.9). Smearable contamination levels also remained high. Four core bores-three on the north wall and one on the east wall-were obtained from the cell. The core samples were taken at the four highest levels of contamination, as determined by direct probe survey (Appendix B, Report B.10). Core bore results indicated that alpha contamination had penetrated as far as $31 / 2$ in. into the concrete block. Areas on the north wall had the highest levels of alpha contamination. Table 2 lists the pre- and post-scabbling contamination levels of smearable alpha contamination for the north wall.

Table 2. North wall alpha contamination, pre- and postscabbling results (smearable)

\begin{tabular}{|c|c|c|}
\hline Block no. & $\begin{array}{l}\text { Pre } 1 / 4 \text {-in removal } \\
\text { alpha }\left(\mathrm{dpm} / 100 \mathrm{~cm}^{2}\right)\end{array}$ & $\begin{array}{l}\text { Post } 1 / 4 \text {-in. removal } \\
\text { alpha }\left(\mathrm{dpm} / 100 \mathrm{~cm}^{2}\right)\end{array}$ \\
\hline 154 & 900,000 & 600 \\
\hline 155 & $1,000,000$ & 1,852 \\
\hline 157 & 850,000 & 11,111 \\
\hline 158 & 900,000 & 6,173 \\
\hline 159 & $1,000,000$ & 1,235 \\
\hline 165 & 220,000 & 3,704 \\
\hline 166 & 160,000 & 2,469 \\
\hline 167 & 400,000 & 1,235 \\
\hline 174 & $2,000,000$ & 3,086 \\
\hline 175 & 300,000 & 4,938 \\
\hline 176 & 170,000 & 617 \\
\hline 180 & 170,000 & 1,235 \\
\hline $181^{*}$ & $>2,500,000$ & 1,235 \\
\hline $182^{*}$ & $1,600,000$ & 1,852 \\
\hline
\end{tabular}

- Indicates access hatch

Note: Smears were taken on blocks from the cell floor up four rows. 
Because contamination levels on the north wall and its access hatch area were high, a sample strip of paint that had been removed from the access hatch was submitted for isotopic analysis. The results of the analysis follow:

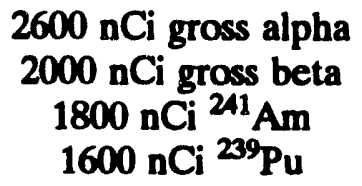

Analysis of the strippable paint that had been removed from other, more representative, areas of the cell indicated much lower contamination levels. However, this paint was still more contaminated than all the other routinely generated waste such as chem wipes, masslin, and protective clothing. Thus, the decision to package the spent strip coat in a divergent container was made.

The cell door frame and access hatch had been decontaminated by April 7, 1993. The Pentek Corner-Cutter worked successfully, removing as much as four layers of paint from these surface areas. The smearable contamination levels on the cell door frame were reduced from $5.0 \times 10^{5} \mathrm{dpm}$ per $100 \mathrm{~cm}^{2}$ to $400 \mathrm{dpm}$ per $100 \mathrm{~cm}^{2}$ and, on the access hatch, were reduced from $>1.0 \times 10^{6} \mathrm{dpm}$ per $100 \mathrm{~cm}^{2}$ to $1.25 \times 10^{5} \mathrm{dpm}$ per $100 \mathrm{~cm}^{2}$ (Appendix $B$, Report B.11). Several areas of the cell door frame and access hatch have relatively high contamination levels that are embedded into the metal surfaces. Both the door frame and the hatch have been painted with the strippable paint and will have to be removed from the cell, properly packaged, and disposed of when Building 3505 is dismantled.

The crew encountered problems when decontaminating the stainless steel floor pan. These problems could be attributed to the acids that had been used in the metal recovery process: the acids had entrapped the contamination deep into the porous surface areas of the stainless steel. The crew aborted use of the Grit Blaster because of the additional volume of waste (approximately $80 \mathrm{ft}^{3}$ ) that would be generated during such a decontamination attempt. The Grit Blaster process would only scarify the surface area of the stainless steel. And, because the contamination was expected to be deeply imbedded, this decontamination technique was impractical.

Several hands-on decontamination efforts were performed on the stainless steel floor pan producing limited results. A decision was made to use Pentek 604 paint, a water-based, nonflammable, copolymer that has potential as a descaling and decontamination agent. When applied to nonporous surfaces, it bonds small molecules with larger molecules by water evaporation. The copolymer contracts upon drying, causing the coating to flake (self release) from the surface and to remove radioactive contamination in the process. However, use of the Pentek 604 paint caused no significant changes in the contamination levels on the stainless steel floor. The final survey (Appendix B, Report B.12) shows no significant variation from the precontamination survey.

On April 16, 1993, ATG had satisfied the contractual agreement to remove $1 / 4$ in. of concrete from the surface area of Cell G. A decision was made to continue decontamination on an estimated $60 \mathrm{ft}^{2}$ of highly contaminated areas of the north, east, and west walls below the 8-ft elevation of the cell (Appendix A, Fig. A.2). The contracting officer representative determined that the highest contamination areas of the north, east, and west walls would be scabbled another $3 / 4$ in. in an attempt to reduce the contamination levels. 
This additional work was a scope change, and modifications to the original contract were required before work could proceed. The time delay associated with these modifications necessitated that several ATG personnel be laid off. On April 16, 1993, three decontamination technicians were laid off. And, on April 20, 1993, one Health Physics (HP) supervisor, one HP technician, and one decontamination supervisor were laid off.

After an extended process involving the DOE procurement department, ATG was allowed to continue with the project on July 26, 1993. The additional 3/4-in. removal was completed on August 23, 1993. The final survey was completed on August 27, 1993 (Appendix B, Report B.12), and ATG demobilization was also completed on this day.

A total of ten 21-gal drums of scabbled waste was generated by the decontamination project. A 5-g sample was taken from each drum and sent for radioisotopic analysis. A 50-g sample from each drum was taken from drums 1, 3, 5, and 7 for U.S. Environmental Protection Agency toxicity characteristic leaching procedure (TCLP) analysis. A radioactive analysis of the concrete medium derived that 2 to $40 \mathrm{nCi} / \mathrm{g}$ of alph: emitting radioisotopes were present, an amount well below the transuranic waste limit of $100 \mathrm{nCi} / \mathrm{g}$. The TCLP results were negative: all Resource Conservation and Recovery Act constituents of the paint, which was part of the final waste form, were below regulatory limits. These results were established by the Analytical Chemistry Division at ORNL.

Each 21-gal drum contained $2.80 \mathrm{ft}^{3}$ of waste, making the total volume of waste contained in the ten drums $28 \mathrm{ft}^{3}$. The ten 21 -gal drums of waste were placed into 55 -gal drums-two 21-gal drums per 55-gal drum-for disposal. The volume of a 55-gal drum is $7.35 \mathrm{ft}^{3}$. Ten 21-gal drums deposited into five 55-gal drums resulted in $5 \times 7.35 \mathrm{ft}^{3}$, or $36.75 \mathrm{ft}^{3}$, of waste generated from Cell $G$ for burial. The average weight of each 21 -gal drum was approximately $200 \mathrm{lb}$. The packing system chosen provided enhanced safety by essentially providing an overpack.

A total of $300.5 \mathrm{ft}^{3}$ of compactible waste was generated during the decontamination project. All waste generated-63 $\mathrm{ft}^{3}$ in February, $84 \mathrm{ft}^{3}$ in March, $53.5 \mathrm{ft}^{3}$ in April, and $100 \mathrm{ft}^{3}$ in August-was disposed of as solid waste. All waste was $<0.1 \mathrm{mrem} / \mathrm{h}$ per container. 


\section{RESULTS AND DISCUSSION}

Decontamination of Cell $G$ was highly successful. The levels of contamination have been reduced to as low as reasonably achievable (Appendix B, Reports B.8 and B.13). Removing contamination from the cell wall areas was an intricate operation. Decontamination became complicated around obstacles such as service mounts and electrical penetrations, which had given contamination a migration path. Grouting lacks the density of concrete; thus, contamination migrated in and around the porous grout to depths much greater than those anticipated. Grouted areas surrounding the cell door, access hatch, and stainless steel floor pan were prime areas for migration of contaminants. Some grouted areas had deteriorated to the point where there was no adherence to the blocks. Grouted areas 5-in.-long and 4-in.-deep collapsed from the blocks in several areas.

Each block of Cell $\mathrm{G}$ was individually surveyed, and the results recorded (Appendix B, Report B.12) were the highest measurable fixed contamination levels of alpha on each block. The grouting in some areas around the blocks were the most highly contaminated areas. The dollar amount budgeted for the project did not allow for performing detailed data surveys such as a radiological survey of the grout.

Contamination levels inside the cell were kept ALARA at all times. With the aid of the strippable paint, contamination levels inside the cell were maintained at $<3000 \mathrm{dpm}$ per $100 \mathrm{~cm}^{2}$ during decontamination operations.

Because of their smearable and fixed contamination levels, the cell door frame, access hatch, and the stainless steel floor pan are, and will remain, the significant areas of concern (Appendix B, Report B.13, pp. 1 and 4). Workers applied strippable paint to the surface areas to avoid the spread of contamination to other areas of the cell and the adjoining areas of the facility.

The stainless steel floor pan is an obstacle that will not easily be overcome. The decontamination experience of ATG personnel leads them to suspect that, in all probability, the alpha contamination has penetrated behind the lip of the pan and under the floor pan area. The smallest fracture at a weld or penetration between the concrete block and the lip of the pan are transcendent regions for contamination to enter. Taking into consideration the years of operation and the amount of liquid radioactive material associated with the facility's recovery process, the contamination level underlying this area could be exceptionally high. Caution should be exercised when this floor plan is removed. 


\section{CONCLUSION}

The MRF Cell G Decontamination Project has been a significant success. The project results have substantiated the success of the use of a commercially available dry decontamination technique that has not been used at ORNL before. Radioactive waste reduction is becoming an important issue at commercial and government burial sites, and the dry decontamination technique is an additional means of achieving waste reduction and eliminating liquid waste. Using this technique to eliminate high contamination levels reduces respiratory protection requirements, engineered controls, and, most importantly, environmental impact. The conclusion is that similar decontamination efforts can be implemented in other MRF process cells and at other facilities where D\&D is anticipated. 


\section{REFERENCES}

1. Decontamination Project Plan for Cell $G$ of the Metal Recovery Facility at Oak Ridge National Laboratory, ORNL/ER/INT-17. Martin Marietta Energy Systems, Inc., Oak Ridge National Laboratory, Oak Ridge, Tennessee. April $\$ 992$.

2. Radiation Protection for Occupational Workers, DOE Order 5480.11. U.S. Department of Energy. Dec. 21, 1988. 
Appendix A VIEWS OF THE METAL RECOVERY FACILITY 


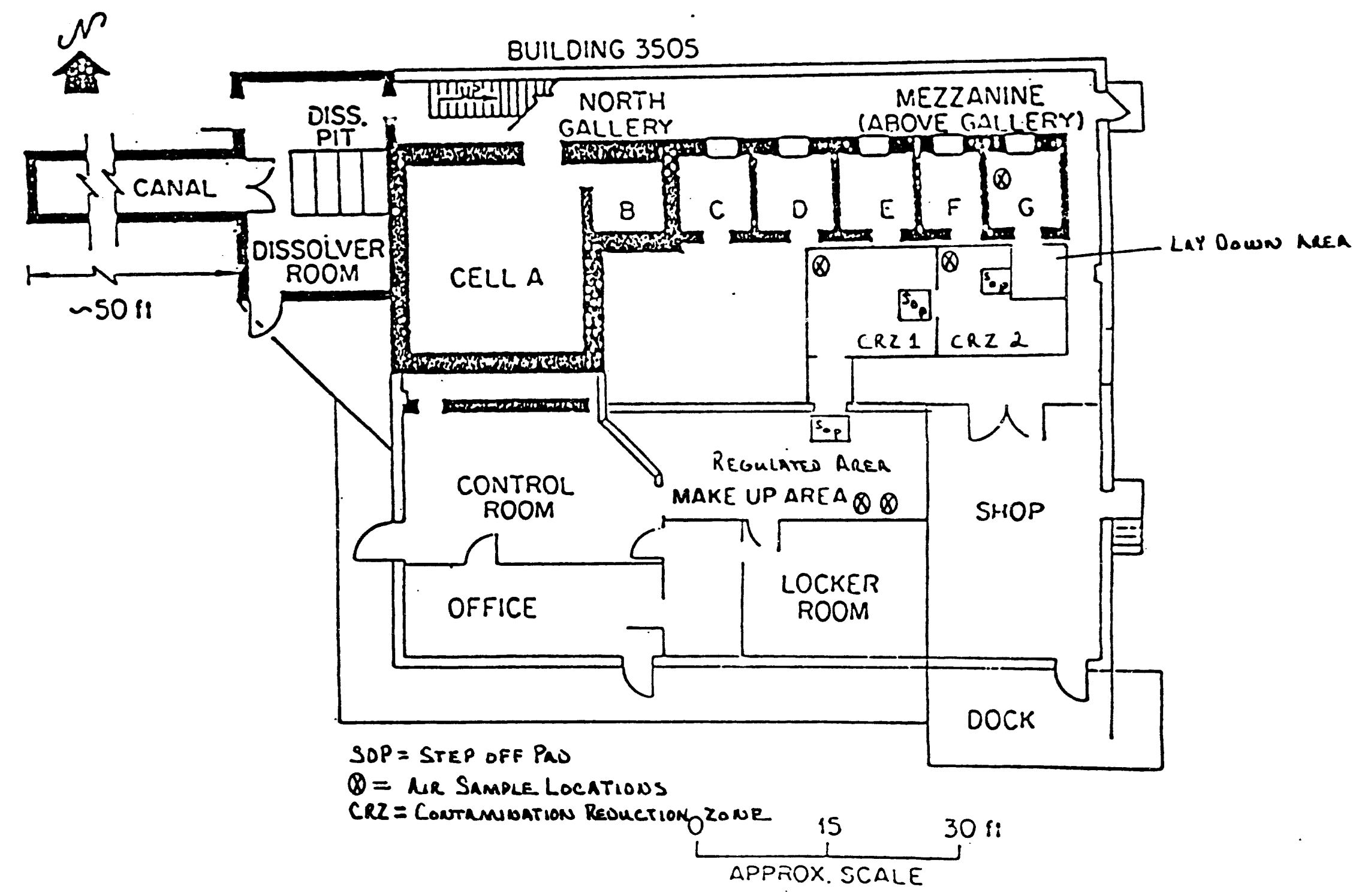

Fig. A1. Layout of the Metal Recovery Facility (Bldg 3505). 


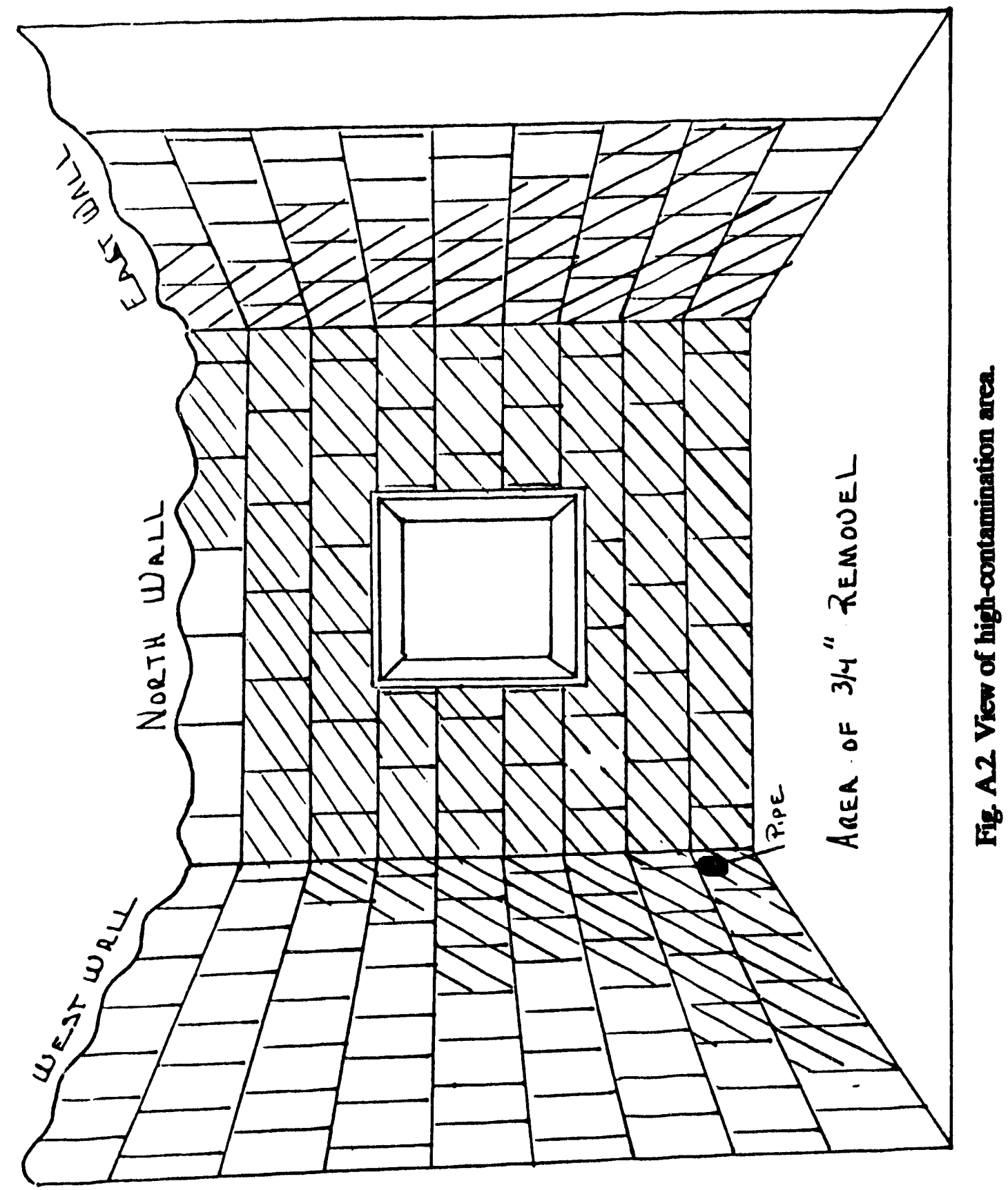


Appendix B

\section{REPORTS}




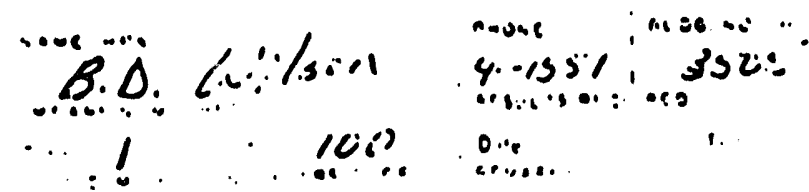

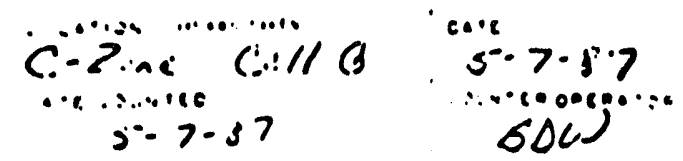

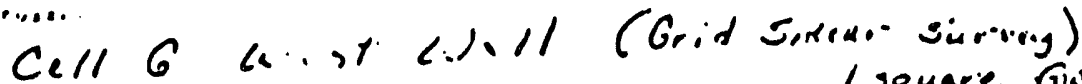
Sine.0.0.s Ficoud for Alplia 1 square rible.

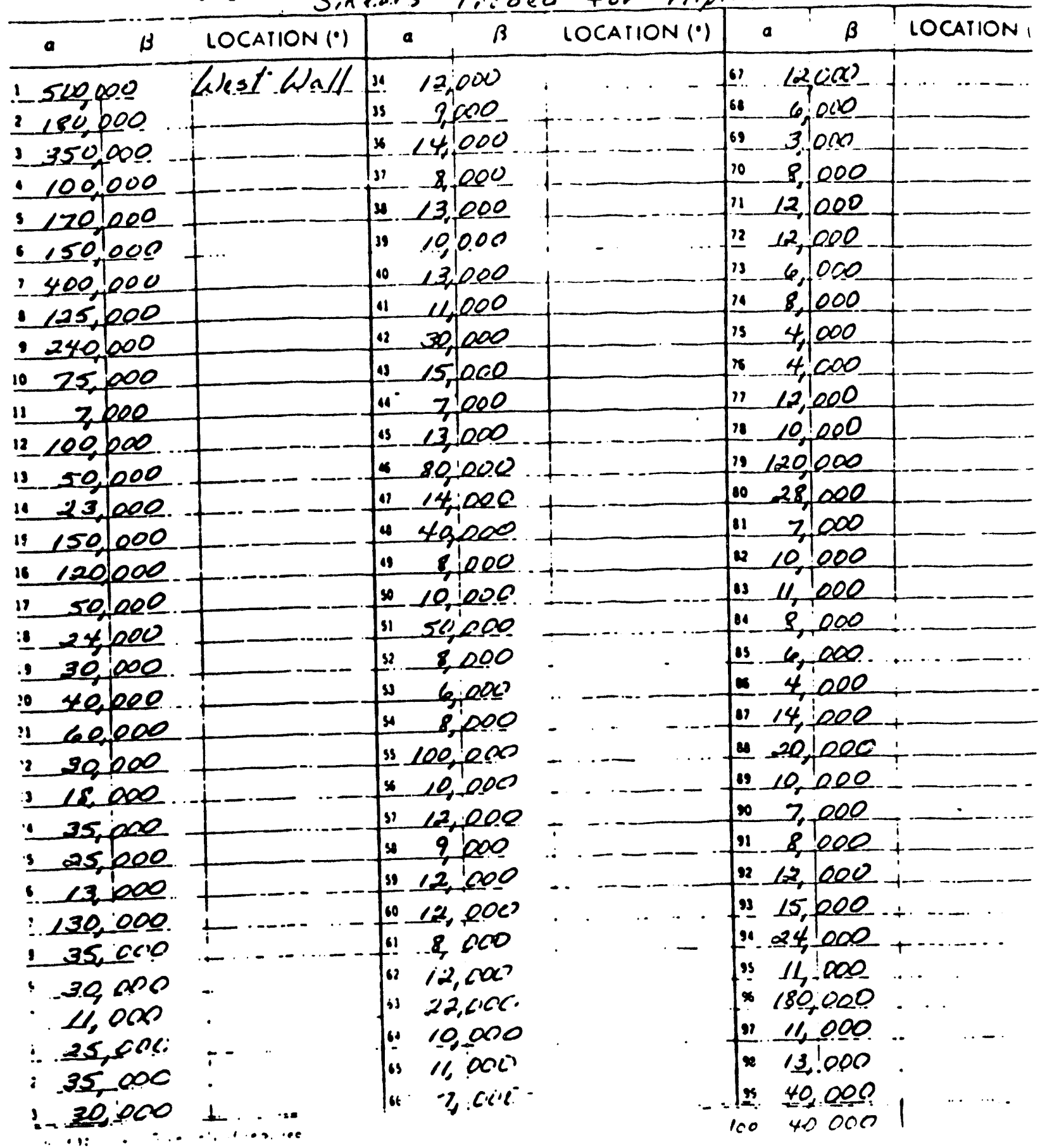

Fig. B.1. Pre-job radiological survey of Bldg. 3505, Cell G 


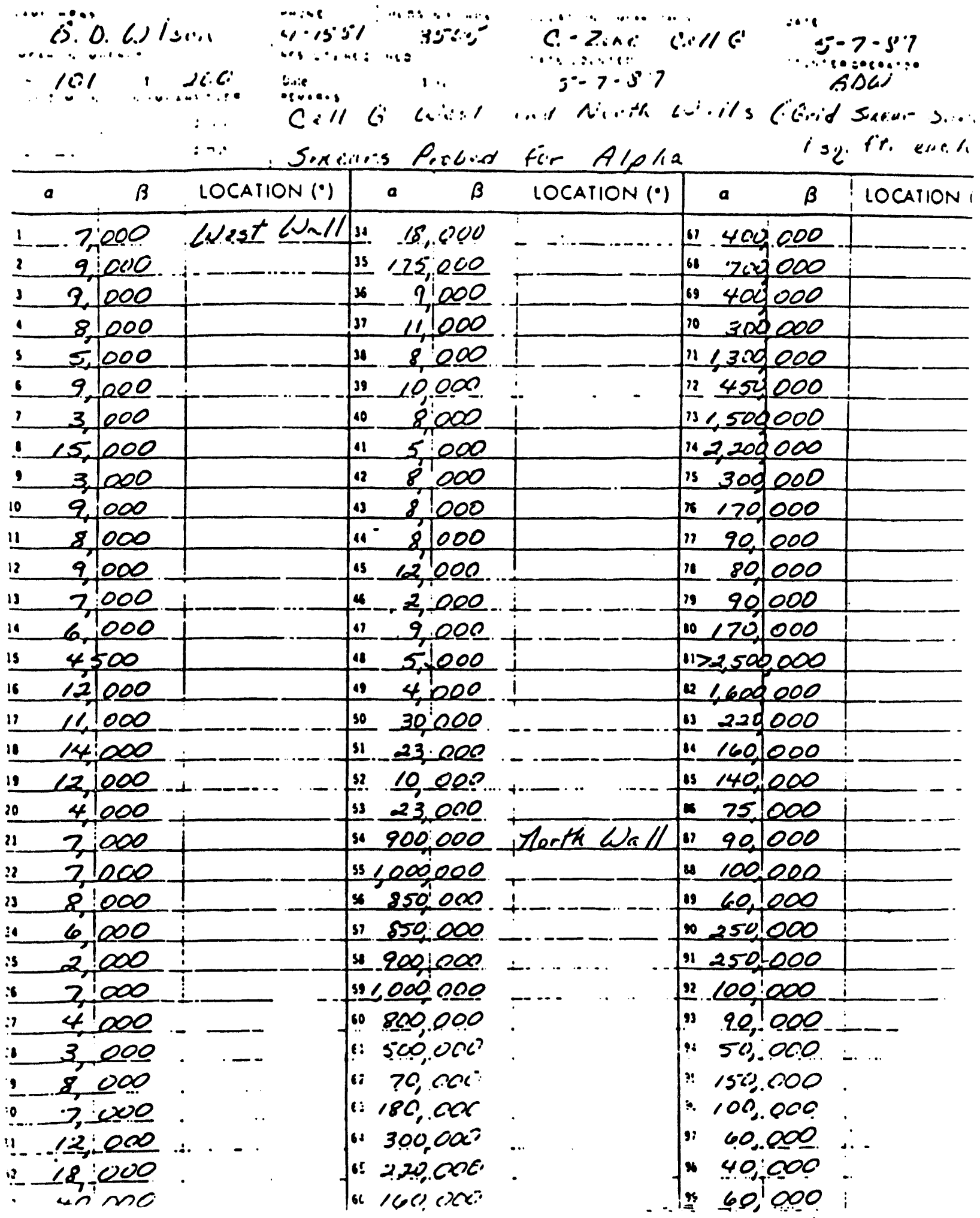

Fig. B.1. (continued) 


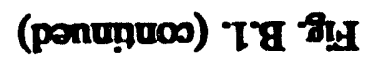

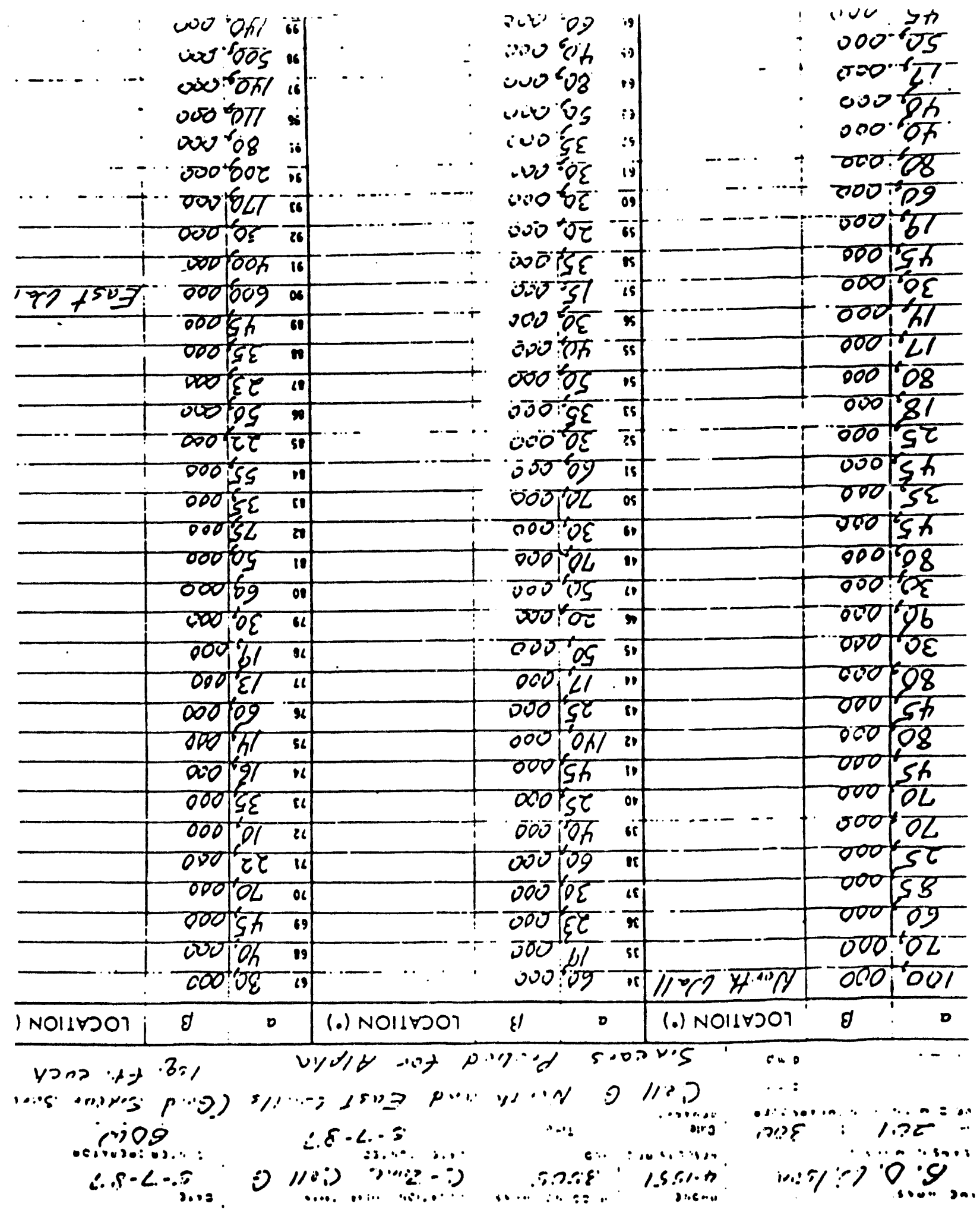




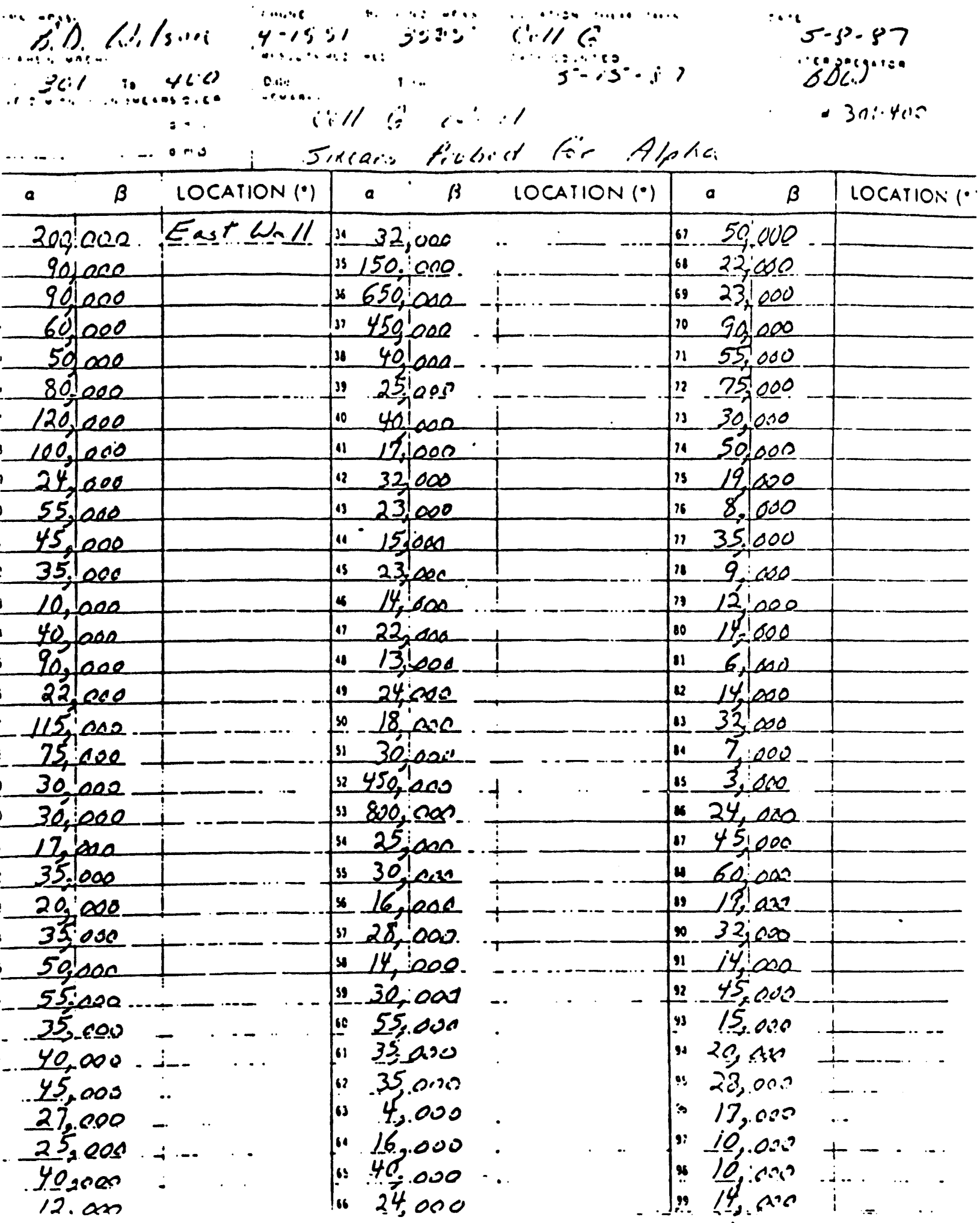

Fig. B.1. (continued) 


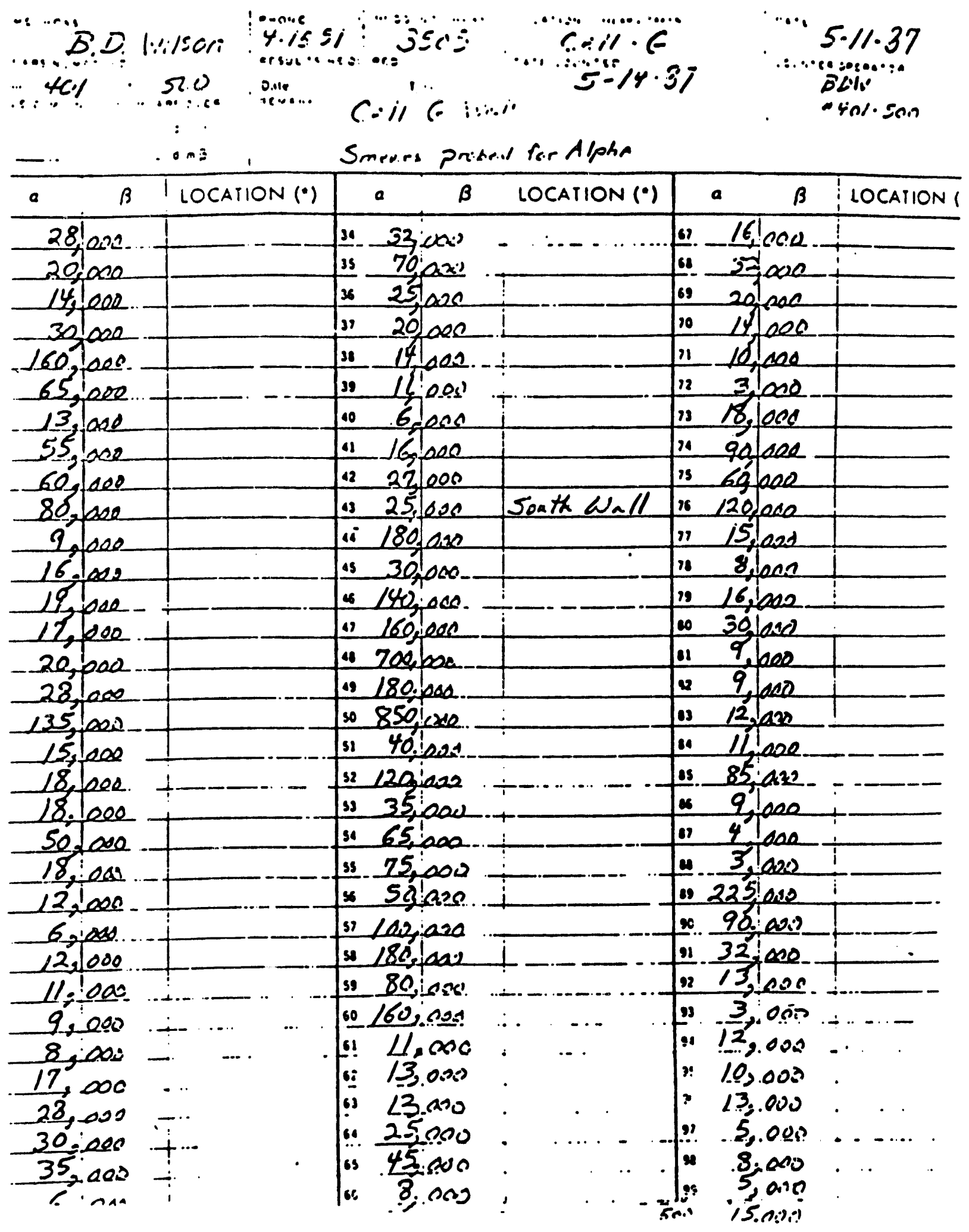

Fig. R.1. (continued) 


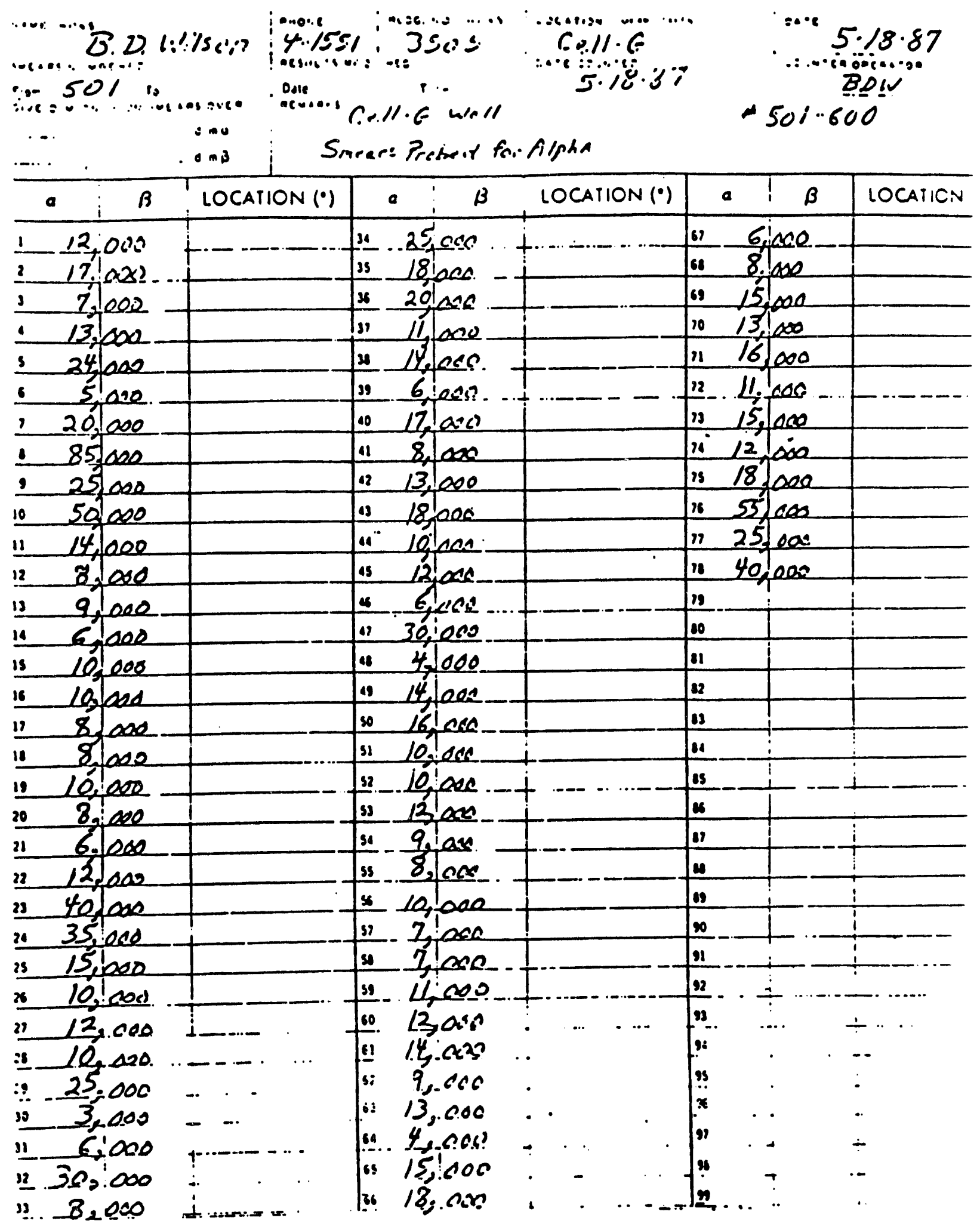

Fig. B.1. (continued) 
B-9

Nertl: liselel

\begin{tabular}{|c|c|c|c|c|c|c|c|}
\hline $2:=$ & $i=l \vdots$ & 1234 & 2855 & 286 & 287 & 288 & 289 \\
\hline 281 & 280 & 279 & 278 & 277 & 276 & 275 & 274 \\
\hline 266 & $2 \sqrt{7}$ & 268 & 269 & 270 & 221 & 272 & 273 \\
\hline 265 & 264 & 263 & $2<2$ & 261 & 260 & 259 & 258 \\
\hline 250 & 251 & 252 & 253 & 254 & 255 & 256 & 257 \\
\hline 249 & 248 & 247 & 246 & 215 & $2 r^{4}$ & 243 & 242 \\
\hline 234 & 235 & 236 & 237 & 238 & 239 & 2.40 & 281 \\
\hline 2.33 & 232 & 231. & 230 & 229 & 228 & 227 & 226 \\
\hline 218 & 219 & 220 & 221 & 272 & 223 & 224 & 225 \\
\hline 217 & 216 & 215 & $2 H$ & 213 & 212 & 211 & 210 \\
\hline 202 & 203 & 204 & 205 & 1206 & $: 207$ & 208 & 208 \\
\hline 201 & 200 & 199 & $-198^{\circ}$ & 192 & 196. & 195 & igy: \\
\hline i86: & 187 & $\therefore 188$ & 189,3 & $2190^{\circ}=$ & $1 \times 91$ & 792 & $\phi_{3}$ \\
\hline 185 & 184 & 183 & 182 & 186 & 180 & 179 & 178 \\
\hline 1.70 & 171 & 172 & $173:$ & 17\%: & 1175 & 176 & 173 \\
\hline 1469 & 108 & 167 & 166 & $16 \dot{S}_{s}$ & 164 & 163 & 1.162 \\
\hline 154 & 155 & 156 & 157 & .158 & 159 & 160: & لـ161. \\
\hline
\end{tabular}

Fif B.1. (continued) 


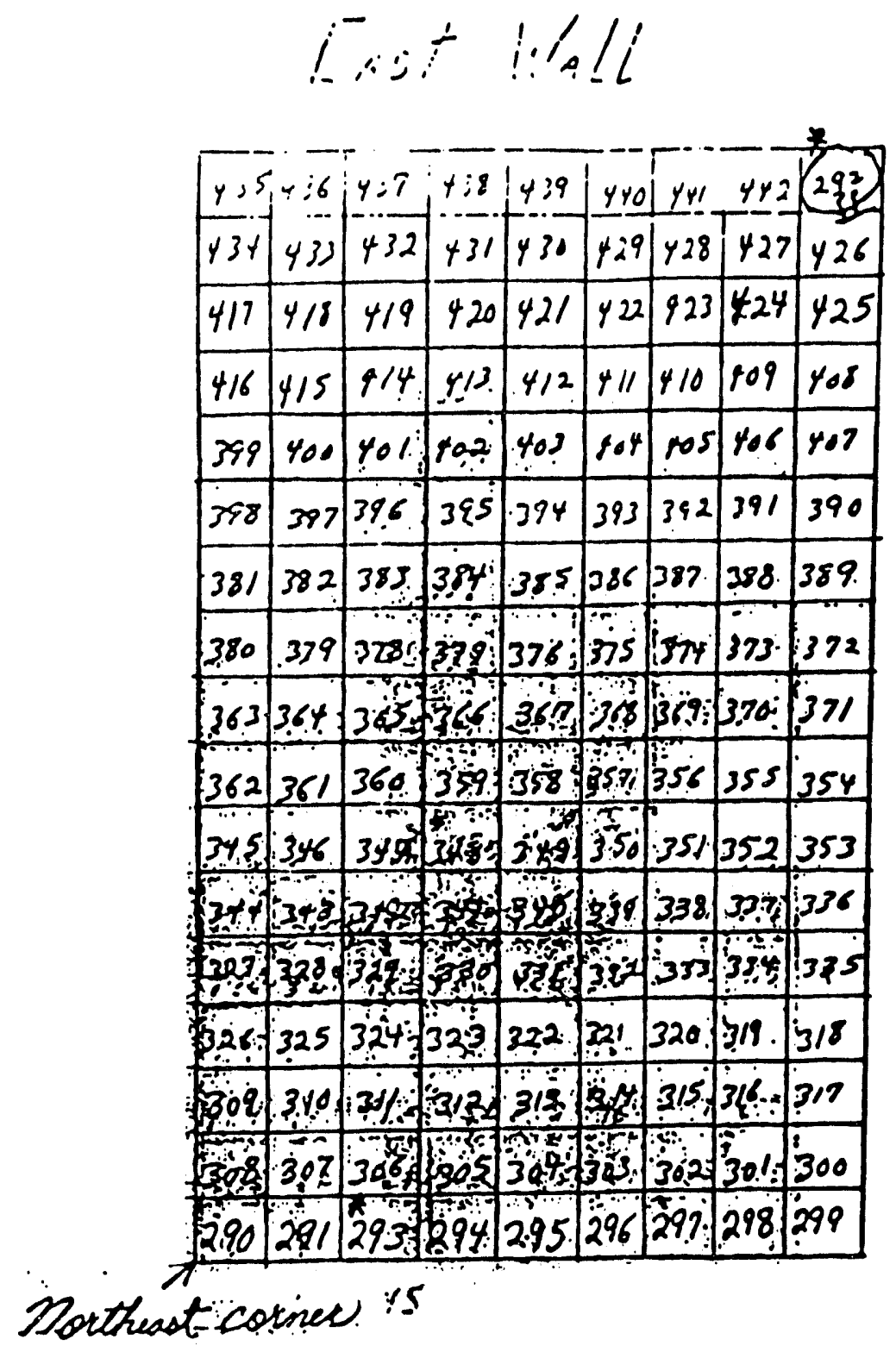

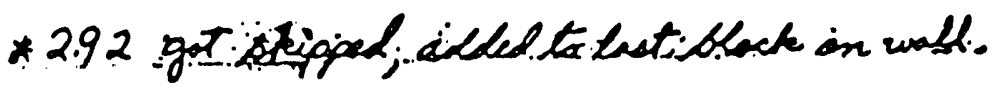

Fig. B.1. (continued) 


\begin{tabular}{|c|c|c|c|c|c|c|c|c|}
\hline 14 & إ. & 147 & $114 i$ & $\left|Y^{\prime}\right|$ & 1501 & 151 & 152 & ij \\
\hline $144:$ & $14 ;$ & 142 & $|14| \mid$ & 140 & 139 & 138 & 137 & 136 \\
\hline 127 & 128 & 129 & 130 & 131 & 132 & 133 & 134 & 135 \\
\hline 126 & 125 & 124 & 123 & 122 & 121 & 120 & 119 & 118 \\
\hline 109 & 110 & 111 & 112 & 113 & 114 & 115 & 116 & 117 \\
\hline 118 & 107 & 106 & 105 & 104 & 103 & 102 & 101 & 100 \\
\hline 91 & 92 & 93 & .94 & 95 & 96 & 97 & 98 & 99 \\
\hline 90 & 89 & 88 & .87 & 86. & 85 & $8: 4$ & 83 & 82 \\
\hline .73 & 74 & $: 75$ & .76 & 77 & .78 & 79 & 80. & 81 \\
\hline 32 & $7 r$ & 70 & 69 & 68. & 67 & 66 & 65 & 64 \\
\hline 55 & 56 & 57. & .58 & .59 & $60^{\circ}$ & 61 & 62 & 63 \\
\hline $54^{\circ}$ & .53 & 52 & $: 5.1$ & 50 & 49: & $48^{\circ}$ & $47^{\circ}$ & 46 \\
\hline 37 & 38 & $: 39:$ & Siso & 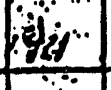 & 72 & $\because 43$ & $34^{\circ}$ & 45 \\
\hline 36 & 35 & 34 & $: 3.3$ & 32 & 36 & 30 & $29^{\circ}$ & 28 \\
\hline 19 & 20 & 21 & iz2: & $x+3$ & 24 & 25 & 26 & 27 \\
\hline $18^{\circ}$ & 17 & $\because 16$ & 19 & $\therefore$ iy. & $\ddot{13}$ & 12 & 111 & 10 \\
\hline$\vdots$ & 2 & 3 & $.4 \div:$ & $\therefore 5$ & 6 & $\therefore 7$ & 8 & 9 \\
\hline
\end{tabular}

Fig. B.1. (contimued) 


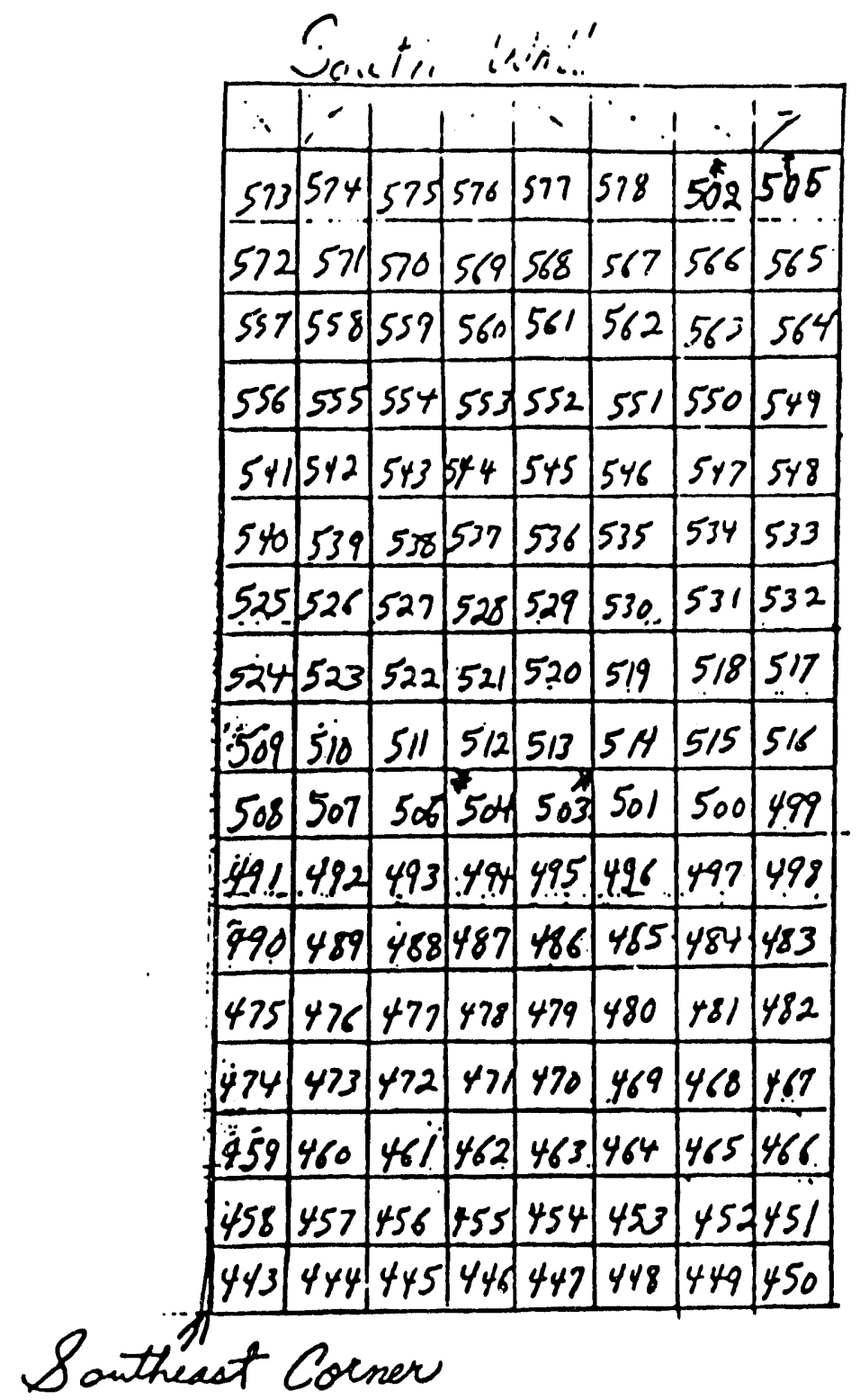

* Numbers 502 a 505 were accidentally skipped, adbed to bar two blocks at tap of wall.

Fig. B.1. (continued) 


\section{RADIOLOGICAL SURVEY REPORT}

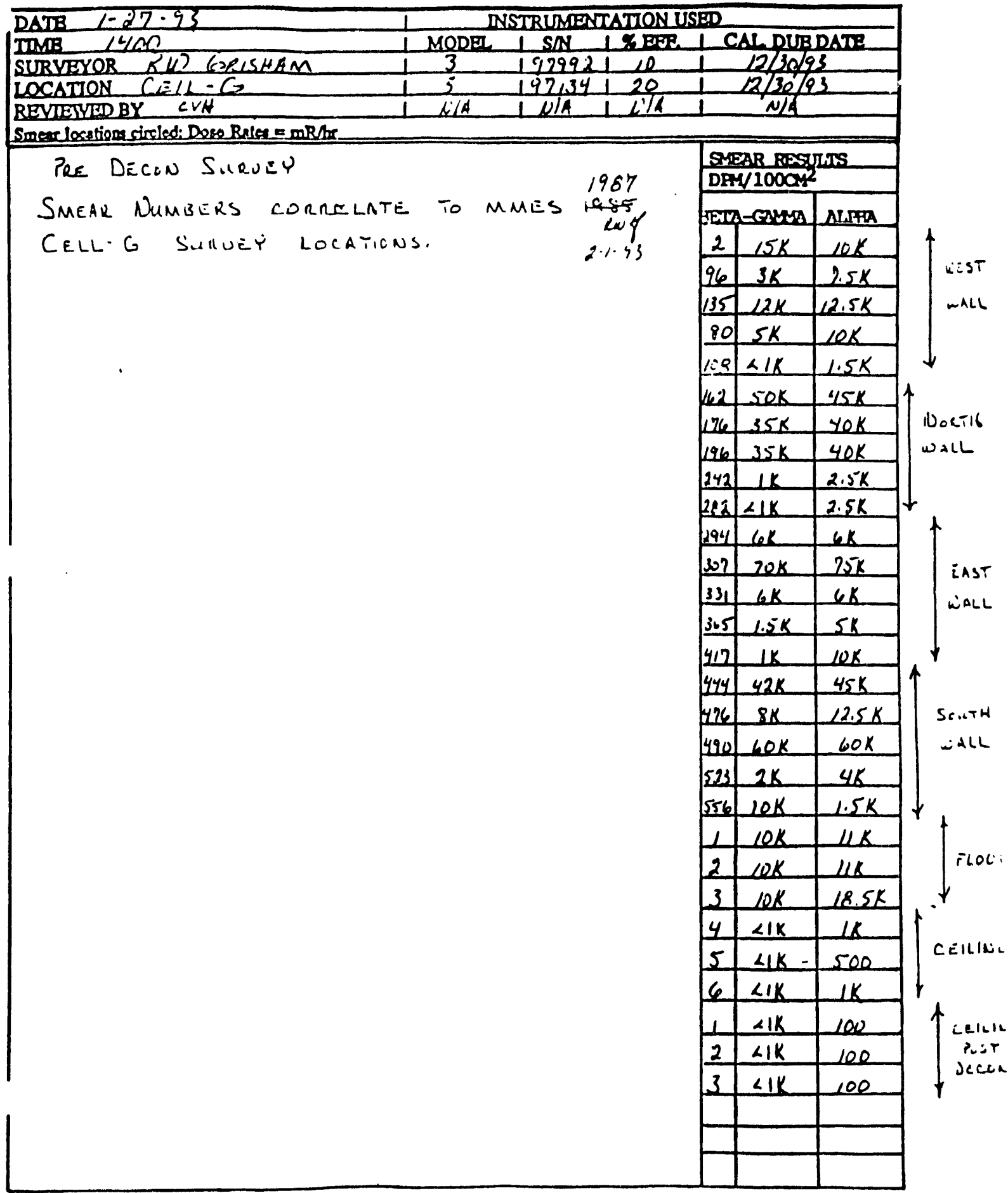

FORM 124

Fig. B2 Radiological survey report, Jan. 27, 1993. 
RADIOLOGICAL SURVEY REPORT

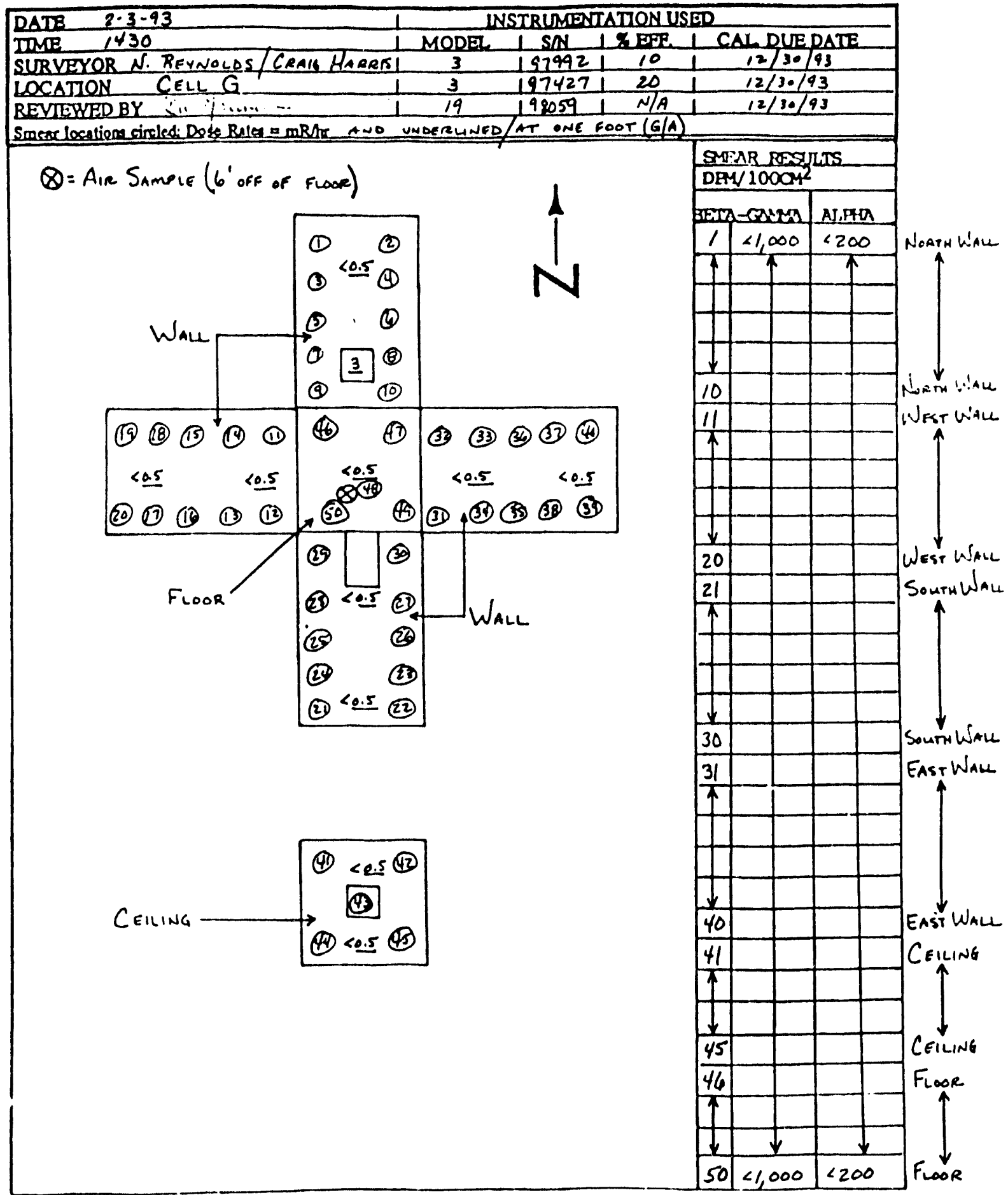

FORM 124

Fig. B3. Radiological survey report, Feb. 3, 1993. 


\section{RADIOLOGICAL SURVEY REPORT}

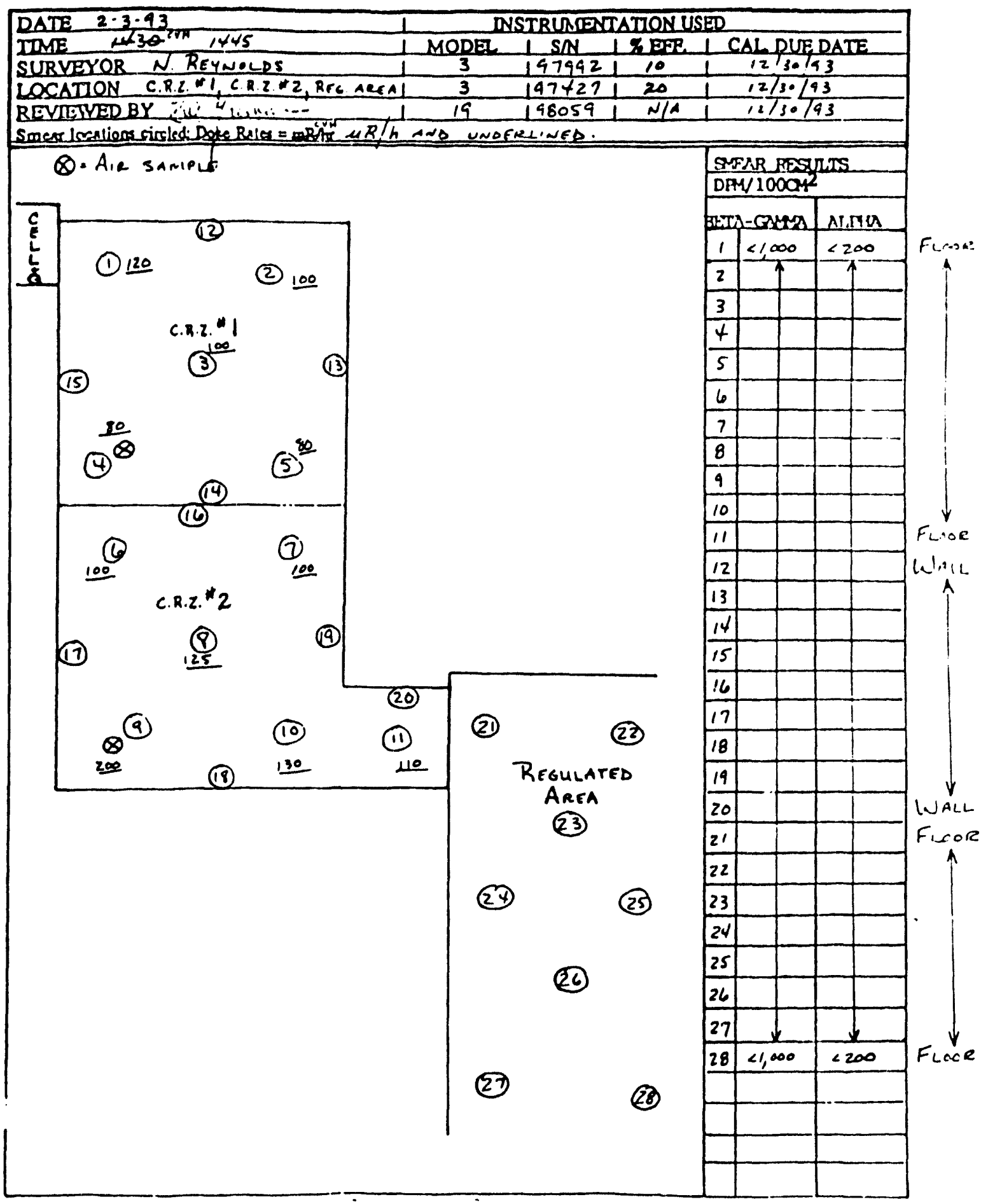

FORM 124

Fiq. B.4. Radiological survey report, Feb. 3, 1993. 
RADIOLOGICAL SURVEY REPORT

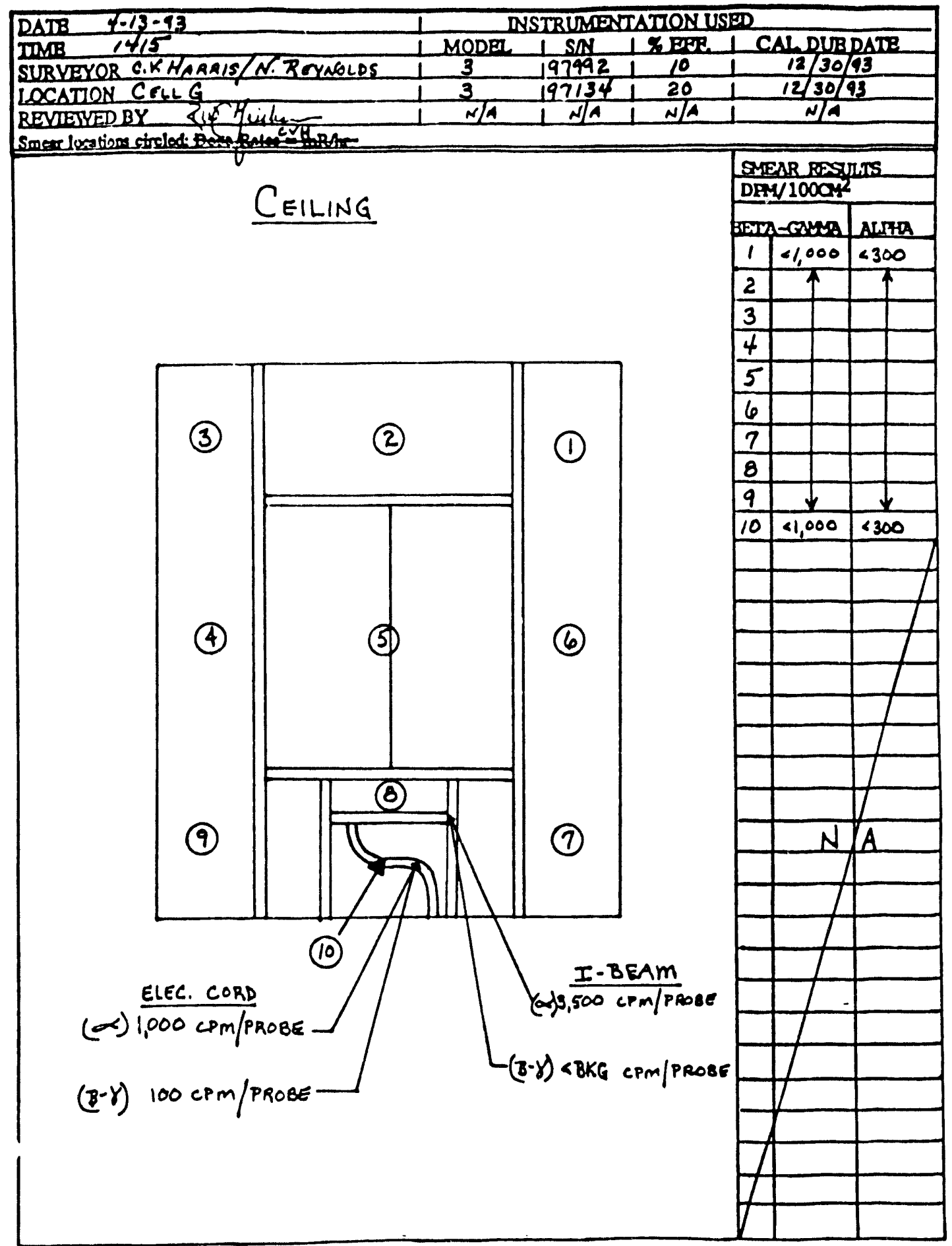

FORM 124

Fig. BS. Radiological survey report, April 13, 1993. 


\section{RADIOLOGICAL SURVEY REPORT}

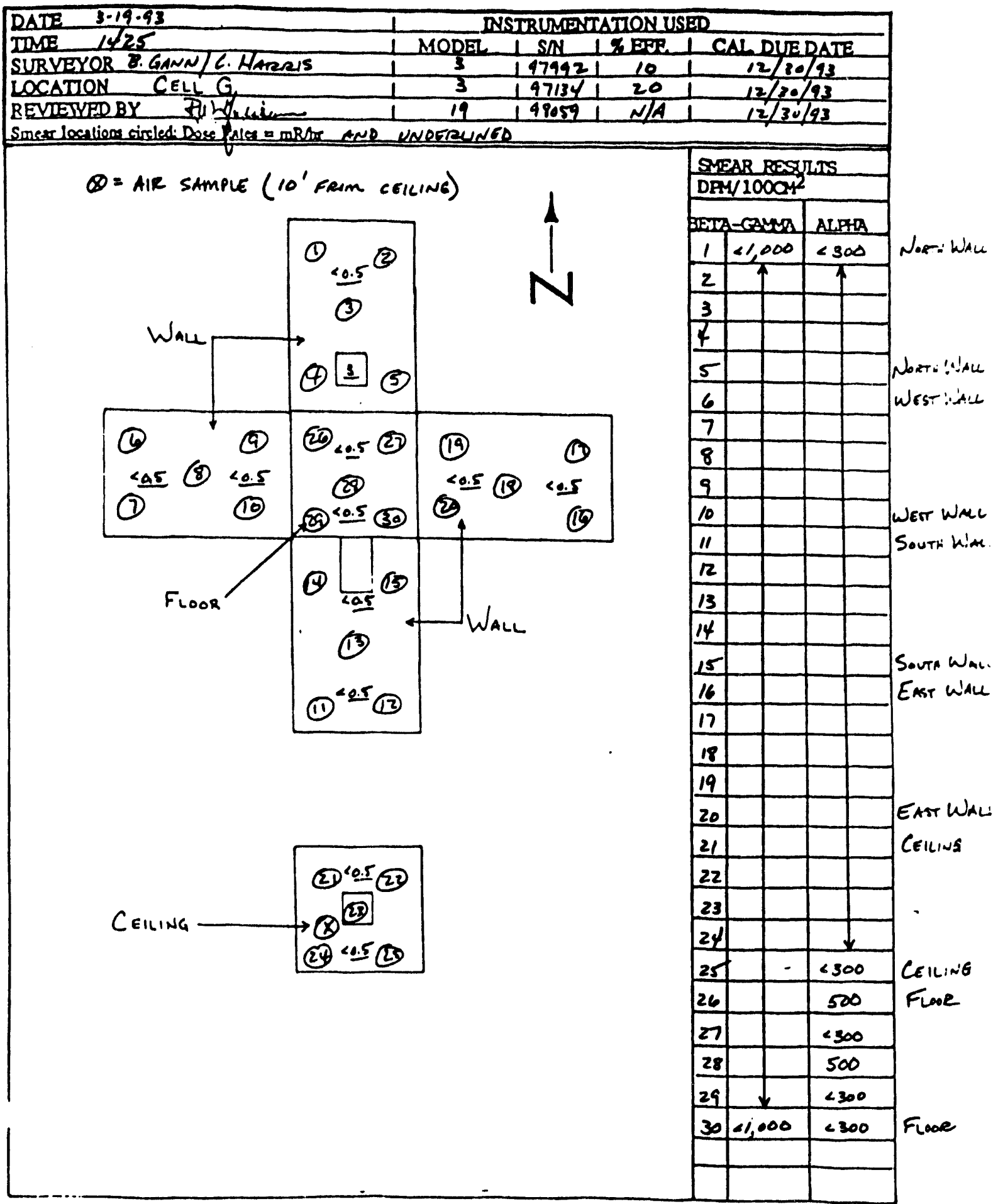

FORM 124

Fig. B.6. Radiological survey report, Mar. 19, 1993. 
B-18

RADIOLOGICAL SURVEY REPORT

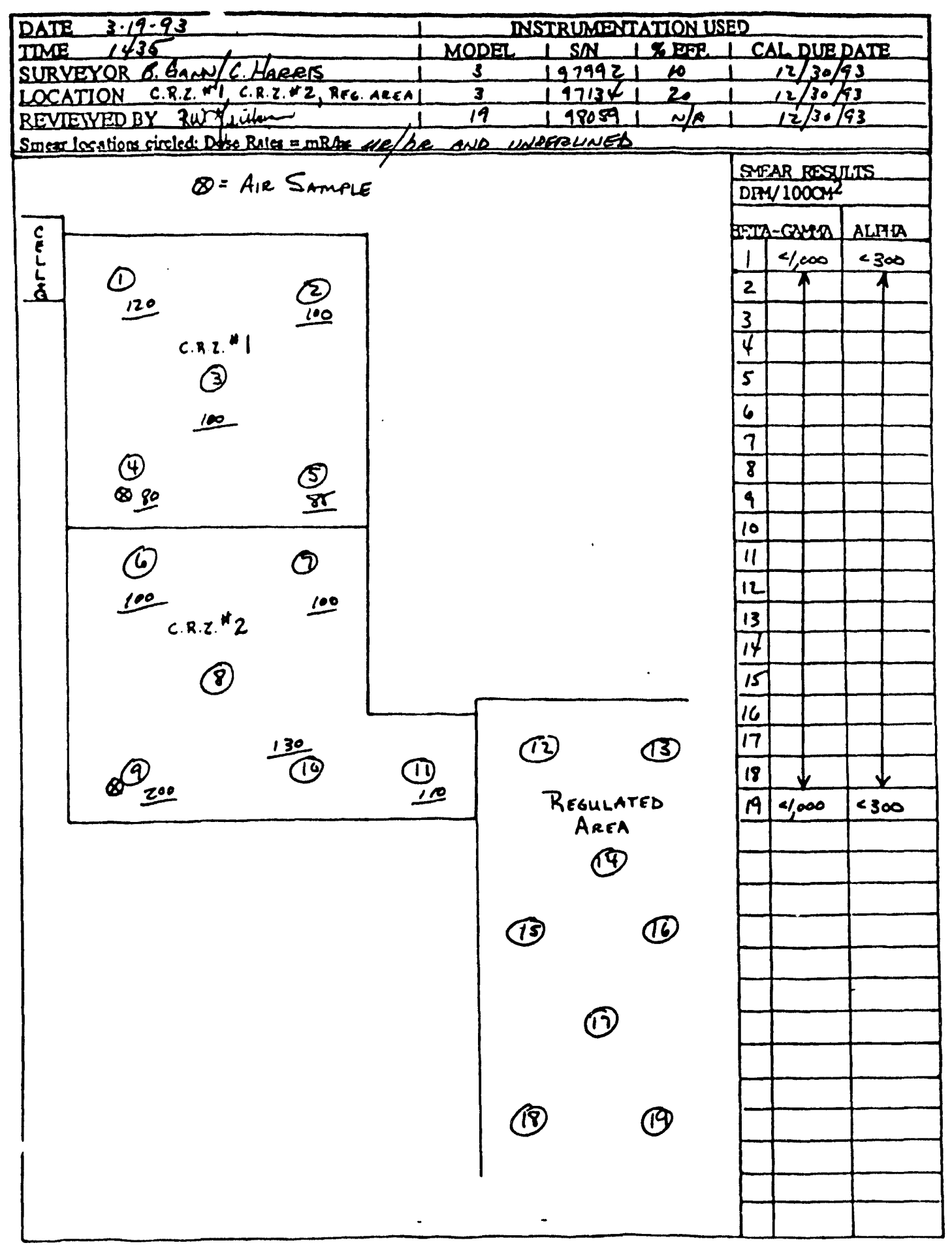

min 194

Fig. B.7. Radiological survey report, Mar. 19, 1993. 
RADIOLOGICAL SURVEY REPORT

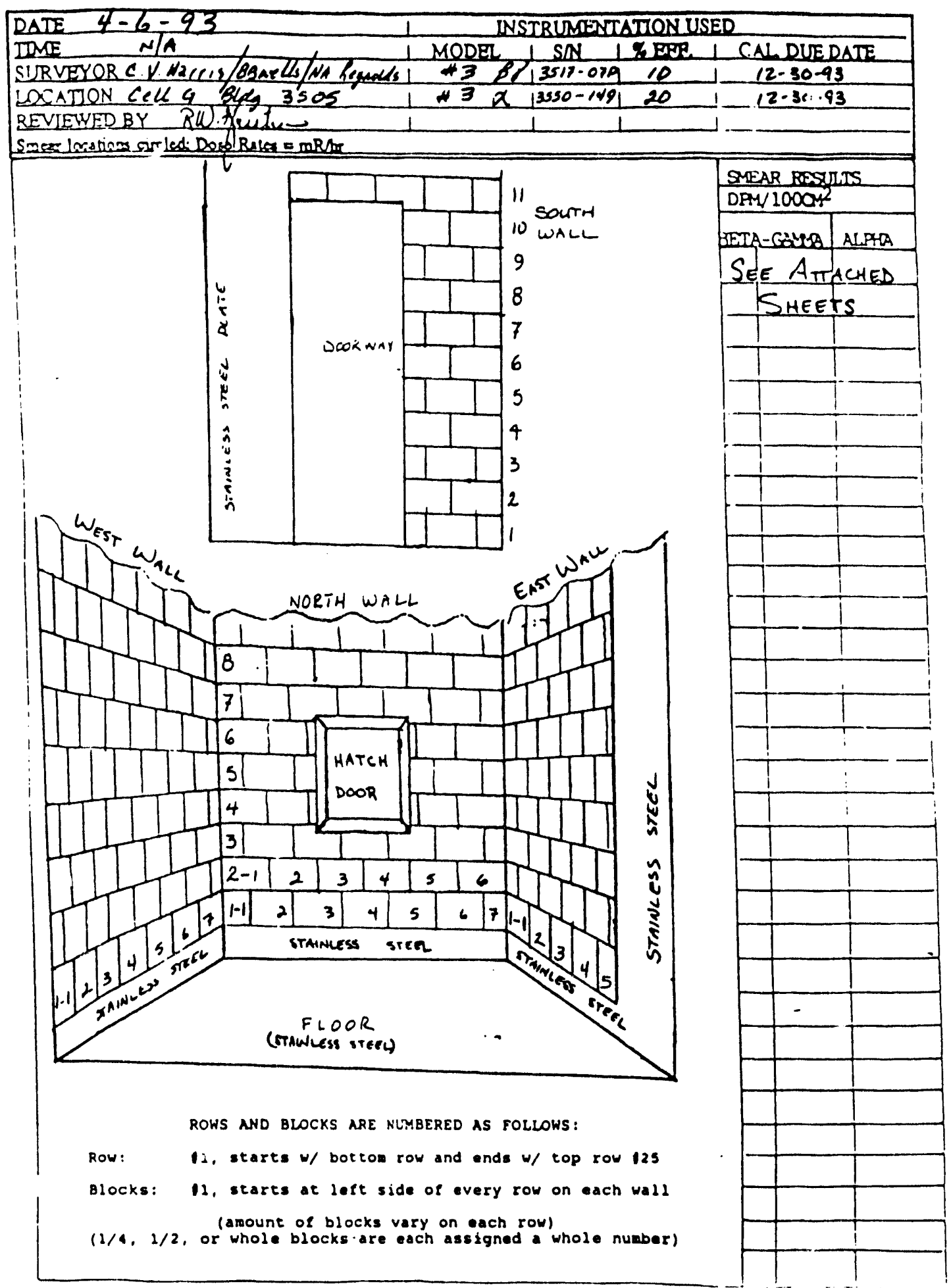

Fig. B.8. Radiological survey report, April 6, 1993. 


\section{B-20}

walt North

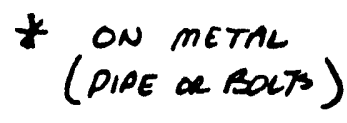

PACE 2 OF 24

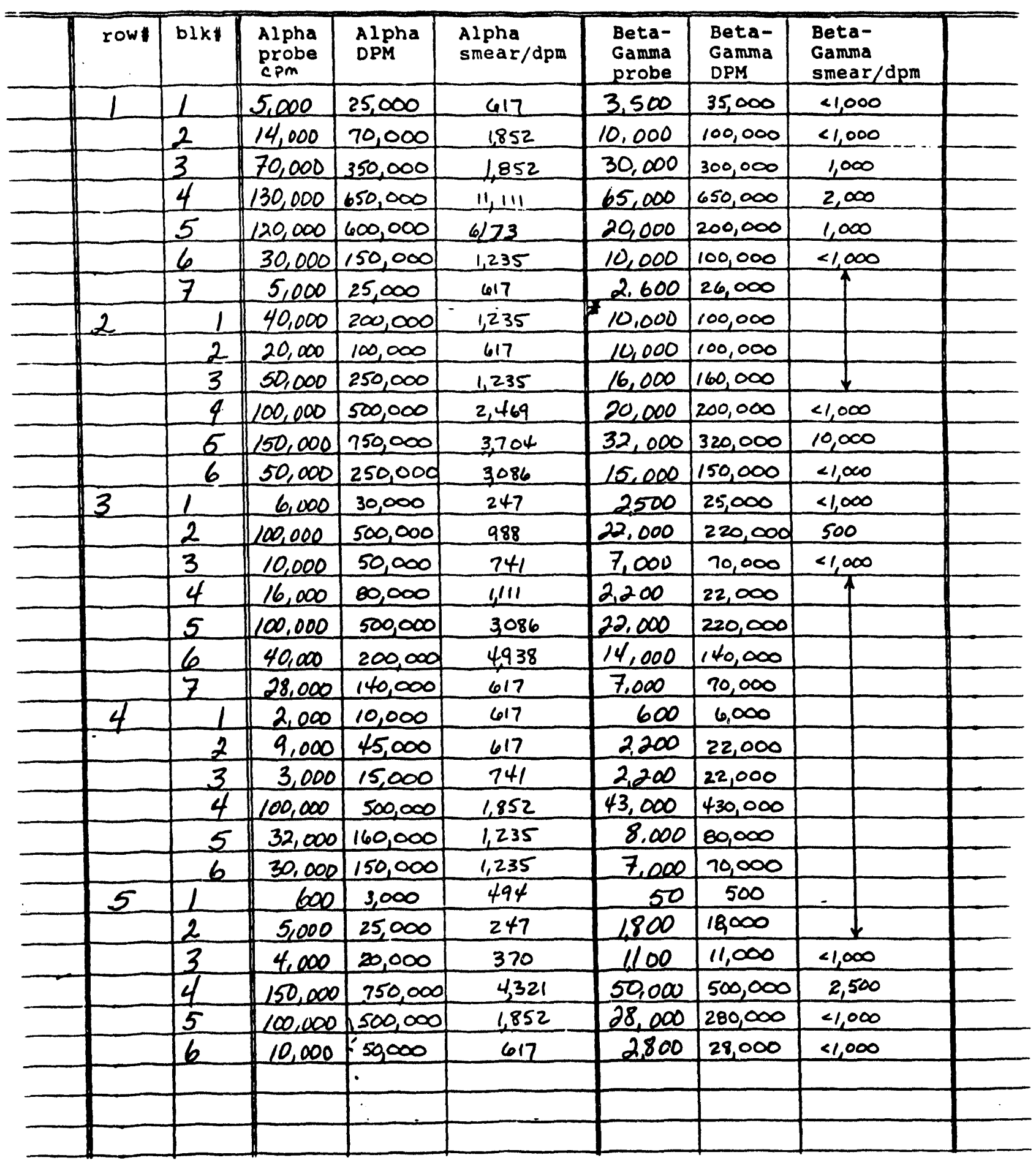

Fig. B8 (continued) 


\section{B-21}

-

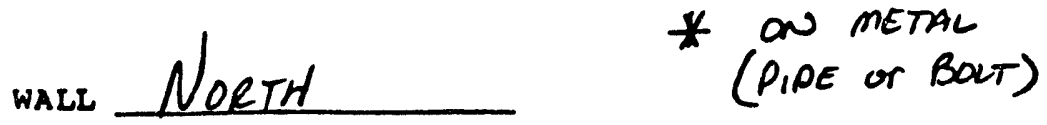

PAGE 3 OF 24

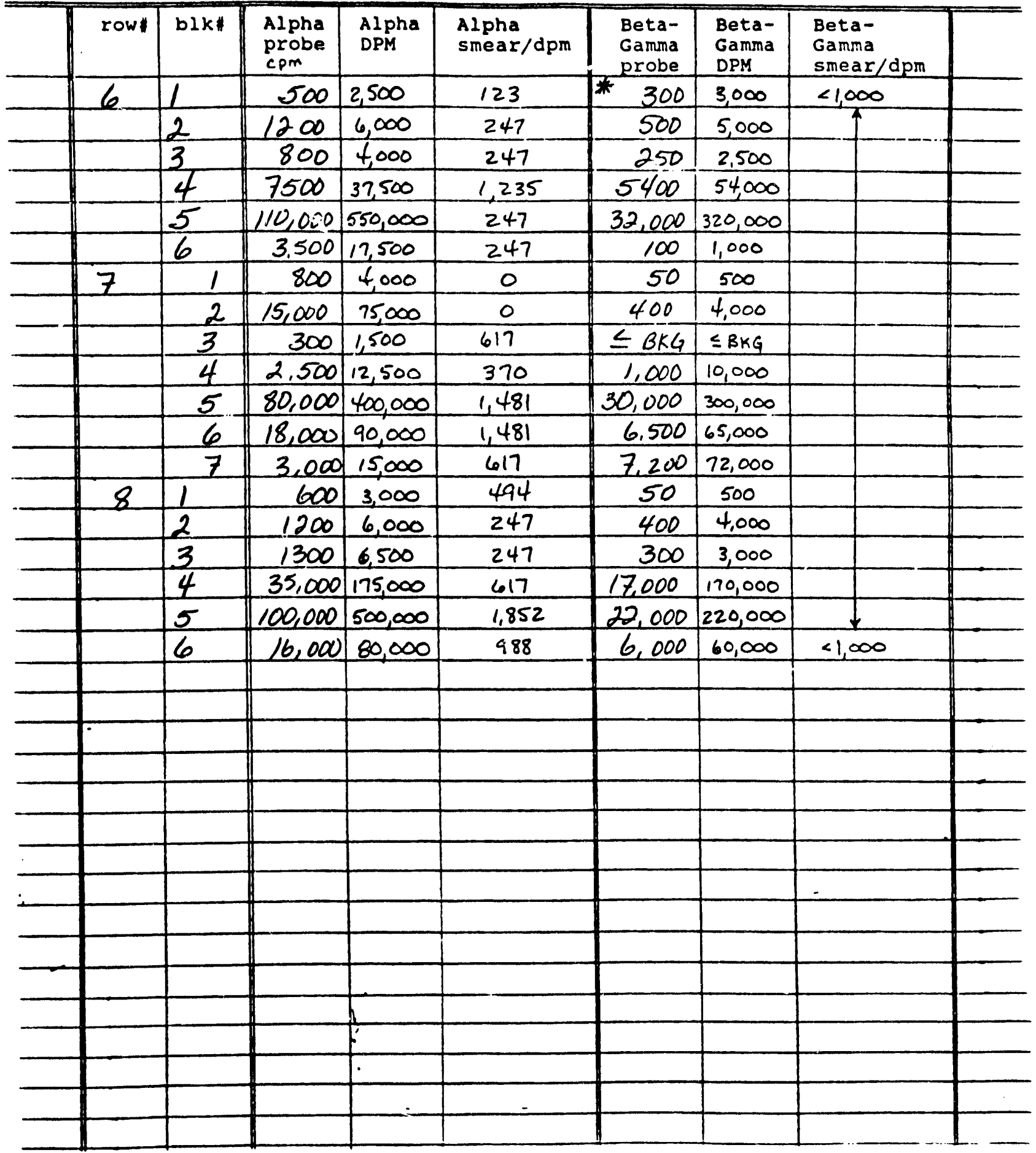

Fig. B8. (continued) 
wazl North * metal (bolt or Pipe)

\begin{tabular}{|c|c|c|c|c|c|c|c|c|}
\hline row: & blk\| & $\begin{array}{l}\text { Alpha } \\
\text { probe }\end{array}$ & $\begin{array}{l}\text { Alpha } \\
\text { DPM }\end{array}$ & $\begin{array}{l}\text { Alpha } \\
\text { smear/dpm }\end{array}$ & $\begin{array}{l}\text { Beta- } \\
\text { Gamma } \\
\text { probe }\end{array}$ & \begin{tabular}{|l} 
Beta- \\
Gamma \\
DPM \\
\end{tabular} & $\begin{array}{l}\text { Beta- } \\
\text { Gamma } \\
\text { smear/dpm }\end{array}$ & \\
\hline 9 & 1 & 800 & 4,000 & 250 & $\leqslant B K G$ & $=6 K G$ & $\leq B K G$ & \\
\hline & 2 & 500 & 2500 & 0 & $\leq B K G$ & $\leq B K G$ & & \\
\hline & 3 & 400 & 2,000 & 0 & 50 & 500 & & \\
\hline & 4 & 2200 & 11,000 & 100 & 700 & 7000 & & \\
\hline & 5 & 6000 & 30,000 & 100 & 2400 & 24,000 & & \\
\hline & 6 & 17,000 & 85,000 & 0 & 5,000 & 50,000 & $x$ & \\
\hline & 7 & 9,000 & 45,000 & 0 & 1600 & 16,000 & 200 & \\
\hline 10 & 1 & 500 & 2500 & 0 & 150 & 1500 & $\leq B K G$ & \\
\hline & 2 & 500 & 2500 & 0 & 200 & 2,000 & & \\
\hline & 3 & 700 & 3500 & 0 & 200 & 2.000 & & \\
\hline & 4 & 500 & 2500 & 250 & 700 & 7,000 & & \\
\hline & 5 & 25,000 & 125,000 & 500 & 3600 & 36,000 & & \\
\hline & 6 & 1,000 & 5,000 & 0 & 120 & 1200 & & \\
\hline 11 & 1 & 300 & 1500 & 0 & 100 & 1000 & & \\
\hline & 2 & 190 & 950 & 0 & $\leq B \times C$ & $\leq B \times 4$ & & \\
\hline & 3 & 210 & 1050 & 0 & $\leq 8,4$ & $\leq 6154$ & & \\
\hline & 4 & 140 & 700 & 0 & 60 & 600 & & \\
\hline & 5 & 5,000 & 25,000 & 250 & 800 & 8.000 & & \\
\hline & 6 & 1200 & 6.000 & 0 & 400 & 4,000 & & \\
\hline & 7 & 150 & 750 & 0 & $\leq 609$ & $\leq 8 \times 4$ & 200 & \\
\hline 12 & 1 & 180 & 900 & 0 & $\leq B B G$ & $\leq 8 \times 4$ & $\leq B K G$ & \\
\hline & 2 & 600 & 3000 & 0 & 100 & 1000 & $\uparrow$ & \\
\hline & 3 & 50 & 250 & 50 & $=B K G$ & $\leq B \times 4$ & & \\
\hline & 4 & 1300 & 6500 & 0 & $\sum B K G$ & $\leq B K G$ & 200 & \\
\hline & 5 & 2700 & 13,500 & 0 & 1000 & 10,000 & $\leq B K G$ & \\
\hline & 6 & 2,800 & 14,000 & 0 & 700 & 7,000 & $\uparrow$ & \\
\hline 13 & 1 & 250 & 1250 & 0 & $\leq B K G$ & $\leq 8 \times 4$ & - & \\
\hline & 2 & 1500 & 7500 & 0 & 400 & 4.000 & & \\
\hline & 3 & 300 & 1,500 & 50 & 250 & 2500 & & \\
\hline & 4 & 50 & 250 & 0 & 150 & 1,500 & $\downarrow$ & \\
\hline & 5 & 40 & 200 & 0 & $\leq B \times G$ & $\leqslant B 5 G$ & 50 & \\
\hline & 6 & 30 & 150 & 0 & $\leq \beta \times 6$ & $\leq B K G$ & $\leq B K G$ & \\
\hline & 7 & 300 & 1,500 & 0 & 100 & 1000 & $\leq B K G$ & \\
\hline & & & & & & & & \\
\hline & & & & & & & & \\
\hline
\end{tabular}

Fig. B8. (continued) 
walr Northy methe (Bolt or Pipe)

\begin{tabular}{|c|c|c|c|c|c|c|c|c|c|}
\hline & rows & b1k & $\begin{array}{l}\text { Alpha } \\
\text { probe }\end{array}$ & $\begin{array}{l}\text { Alpha } \\
\text { DPM }\end{array}$ & $\begin{array}{l}\text { Alpha } \\
\text { smear/dpm }\end{array}$ & $\begin{array}{l}\text { Beta- } \\
\text { Gamma } \\
\text { probe }\end{array}$ & $\begin{array}{l}\text { Beta- } \\
\text { camma } \\
\text { DPM }\end{array}$ & $\begin{array}{l}\text { Beta- } \\
\text { Gamma } \\
\text { smear } / \mathrm{dpm}\end{array}$ & \\
\hline & 14 & 1 & 600 & 3000 & 0 & 120 & 1.200 & $\leq 3 \times 6$ & \\
\hline & & 2 & 1000 & 5000 & 0 & 420 & 4200 & 150 & \\
\hline & & 3 & 40 & 200 & 0 & $\leq \theta \times a$ & $\leq B \times G$ & $\leq B K G$ & \\
\hline & & 4 & 100 & 500 & 50 & 个 & $\uparrow$ & 不 & \\
\hline & & 5 & 50 & 250 & 0 & & & & \\
\hline & & 6 & 120 & 600 & 0 & & & & \\
\hline & 15 & 1 & 80 & 400 & 0 & $\downarrow$ & 1 & & \\
\hline & & 2 & 1500 & 7500 & 0 & 100 & 1000 & & \\
\hline & & 3 & 700 & 3500 & 0 & 140 & 1400 & & \\
\hline & & 4 & 50 & 250 & 0 & $\leq B B G$ & $\leq 8 K G$ & & \\
\hline & & $\frac{5}{5}$ & 60 & 300 & 0 & & $\uparrow$ & & \\
\hline & & 6 & 60 & 300 & 250 & $\sqrt{2}$ & 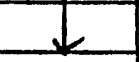 & & - \\
\hline & & 7 & 130 & 650 & 250 & 20 & 200 & & \\
\hline & 16 & 1 & 300 & 1500 & 0 & 100 & 1000 & & \\
\hline & & 2 & 1000 & 5,000 & 0 & 100 & 1000 & & \\
\hline & & 3 & 80 & 400 & 0 & $\leq B K G$ & $\leq 8 \times 4$ & & \\
\hline & & 4 & 70 & 350 & 0 & & & & - \\
\hline & & 3 & 50 & 250 & 0 & & & & $\bar{T}$ \\
\hline & & 6 & 130 & 650 & 0 & & & & \\
\hline & 17 & 1 & 20 & 100 & 0 & $\downarrow$ & $\checkmark$ & & 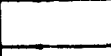 \\
\hline & & 2 & 2500 & 12500 & 0 & 600 & 6000 & & \\
\hline & & 3 & 20 & 100 & 0 & 40 & 400 & & \\
\hline & & 4 & 100 & 500 & 0 & 50 & 500 & & - \\
\hline & & 5 & 40 & 200 & 0 & 30 & 300 & & \\
\hline & & 6 & 50 & 250 & 0 & $\leq B K S$ & $\leq B K G$ & & - \\
\hline & & 7 & 20 & 100 & 0 & & & & \\
\hline & 18 & 1 & 200 & 1000 & 0 & & & & 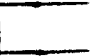 \\
\hline & & 2 & 4,000 & 20,000 & 150 & 750 & 7,500 & & - \\
\hline & & 3 & 40 & 200 & 0 & $\leq B \times G$ & $\leq B K G$ & & - \\
\hline & & 4 & 40 & 200 & 0 & 50 & 500 & & 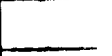 \\
\hline & & 5 & 20 & 100 & 0 & $\leq B K C$ & $\leq-6 \times<$ & $\leq B K 4$ & 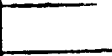 \\
\hline & & 6 & 20 & 100 & 0 & 50 & 500 & 100 & \\
\hline & & & & & & & & & \\
\hline & & & & & & & & & \\
\hline
\end{tabular}

Fig. B.8. (continued) 
wall Northe $*$ metal (Bolt or Plpe)

\begin{tabular}{|c|c|c|c|c|c|c|c|}
\hline row: & blk: & $\begin{array}{l}\text { Alpha } \\
\text { probe }\end{array}$ & $\begin{array}{l}\text { Alpha } \\
\text { DPM }\end{array}$ & $\begin{array}{l}\text { Alpha } \\
\text { smear/dpm }\end{array}$ & $\begin{array}{l}\text { Beta- } \\
\text { Gamma } \\
\text { probe }\end{array}$ & $\begin{array}{l}\text { Beta- } \\
\text { Gamma } \\
\text { DPM }\end{array}$ & $\begin{array}{l}\text { Beta- } \\
\text { Gamma } \\
\text { smear/dpm }\end{array}$ \\
\hline \multirow{7}{*}{19} & 1 & 500 & 2500 & 0 & 300 & 3000 & $\leq B K G$ \\
\hline & 2 & 500 & 2500 & 0 & 250 & 2500 & , \\
\hline & 3 & 500 & 2500 & 0 & 140 & 1400 & \\
\hline & 4 & 500 & 2500 & O & 60 & 600 & $x$ \\
\hline & 5 & 50 & 250 & 60 & $\leq B \times 6$ & $\leq B K G$ & 200 \\
\hline & 6 & 50 & 250 & 0 & $\uparrow$ & 1 & $\leq B K C$ \\
\hline & 7 & 50 & 250 & 0 & & & \\
\hline \multirow[t]{6}{*}{20} & 1 & 250 & 1250 & 0 & $x$ & & \\
\hline & 2 & 400 & 2000 & 0 & 140 & 1400 & \\
\hline & 3 & 40 & 200 & 0 & $\leq B \times 4$ & $\leq B \times G$ & \\
\hline & 4 & 20 & 100 & 50 & 40 & 400 & \\
\hline & 5 & 50 & 250 & 0 & 20 & 200 & \\
\hline & 6 & 260 & 1300 & 150 & $\leq 6 \times G$ & $\leq B 54$ & \\
\hline \multirow[t]{7}{*}{21} & 1 & 200 & 1000 & 0 & 80 & 800 & \\
\hline & 2 & 1000 & 5000 & 0 & 300 & 3000 & \\
\hline & 3 & 700 & 3500 & 0 & 400 & 4000 & \\
\hline & 4 & 1200 & 6000 & 0 & 800 & 8000 & \\
\hline & 5 & 100 & 500 & 0 & 200 & 2000 & \\
\hline & 6 & 300 & 1500 & 30 & 40 & 400 & \\
\hline & 7 & 30 & 150 & 0 & 20 & 200 & \\
\hline \multirow[t]{6}{*}{22} & 1 & 600 & 3000 & 0 & $\leq B \times G$ & $\leq B \times 2$ & \\
\hline & 2 & 300 & 1500 & 0 & $\uparrow$ & $\uparrow$ & \\
\hline & 3 & 30 & 150 & 0 & \pm & 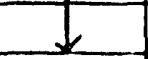 & \\
\hline & 4 & 20 & 100 & 0 & 50 & 500 & 300 \\
\hline & 5 & 30 & 150 & 0 & $\leq \beta, B G$ & $\leq \beta 54$ & $\leq B 5 G$ \\
\hline & 6 & 20 & 100 & 0 & & $\uparrow$ & 1 \\
\hline \multirow[t]{9}{*}{23} & 1 & 60 & 300 & 0 & & & \\
\hline & 2 & 30 & 150 & 0 & & & \\
\hline & 3 & 20 & 100 & 0 & & & \\
\hline & 4 & 60 & 300 & 0 & & & \\
\hline & 5 & 30 & 150 & 0 & $\downarrow$ & $x$ & \\
\hline & 6 & 40 & 200 & 0 & 50 & 500 & $x$ \\
\hline & 7 & 30 & 150 & 0 & $\leq B \times 4$ & $\leq B K G$ & 200 \\
\hline & & & & & & & \\
\hline & & & & & & & \\
\hline
\end{tabular}

Fig. B8. (continued) 
WALL NORTH N mETAL (BOLT OR PIPE) ${ }^{24}$

\begin{tabular}{|c|c|c|c|c|c|c|c|}
\hline row" & blkt & $\begin{array}{l}\text { Alpha } \\
\text { probe }\end{array}$ & $\begin{array}{l}\text { Alpha } \\
\text { DPM }\end{array}$ & $\begin{array}{l}\text { Alpha } \\
\text { smear/dpm }\end{array}$ & $\begin{array}{l}\text { Beta- } \\
\text { Gamma } \\
\text { probe }\end{array}$ & $\begin{array}{l}\text { Beta- } \\
\text { Gamma } \\
\text { DPM } \\
\end{array}$ & $\begin{array}{l}\text { Beta- } \\
\text { Gamma } \\
\text { smear/dpm }\end{array}$ \\
\hline \multirow[t]{6}{*}{24} & 1 & 20 & 100 & 0 & $\leq$ & $\leq$ & 100 \\
\hline & 2 & 30 & 150 & 0 & 50 & 500 & 200 \\
\hline & 3 & 20 & 100 & 0 & 50 & 500 & $\leq B K G$ \\
\hline & 4 & 20 & 100 & 0 & 50 & 500 & 不 \\
\hline & 5 & 20 & 100 & 0 & 50 & 500 & \\
\hline & $b$ & 20 & 100 & 60 & $\leqslant B \times 4$ & $\leq B K G$ & \\
\hline \multirow{7}{*}{25} & 1 & 50 & 250 & 0 & $\leq B K G$ & $\leq B K G$ & \\
\hline & 2 & 150 & 750 & 60 & 50 & 500 & \\
\hline & 3 & 40 & 200 & 250 & 150 & 1500 & \\
\hline & 4 & 20 & 100 & 90 & 150 & 1500 & \\
\hline & 5 & 20 & 100 & 0 & 250 & 2500 & \\
\hline & 6 & 20 & 100 & 0 & 100 & 1000 & $\downarrow$ \\
\hline & 7 & 50 & 250 & 60 & 100 & 1000 & $\leq B K G$ \\
\hline & & & & & & & \\
\hline & & & & & & & \\
\hline & & & & & & & \\
\hline & & & & & & & \\
\hline & & & & & & & \\
\hline & & & & & & & \\
\hline & & & & & & & \\
\hline & & & & & & & \\
\hline & & & & & & & \\
\hline & & & & & & & \\
\hline & & & & & & & \\
\hline & 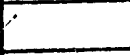 & & & & & & - \\
\hline & & & & & & & \\
\hline & & & & & & & \\
\hline & & & & $\therefore$ & & & \\
\hline & & & & & & & \\
\hline & & & & & & & \\
\hline & & & {[} & & & & \\
\hline & & & & - & & & \\
\hline & & & & & & & \\
\hline
\end{tabular}

Fis. B\& (continued) 
wald East

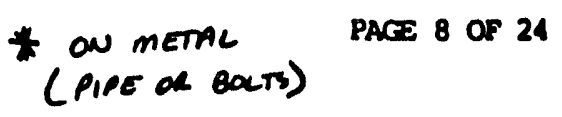

\begin{tabular}{|c|c|c|c|c|c|c|c|}
\hline row & blk & $\begin{array}{l}\text { Alpha } \\
\text { probe } \\
\text { cpm }\end{array}$ & $\begin{array}{l}\text { Alpha } \\
\text { DPM }\end{array}$ & $\begin{array}{l}\text { Alpha } \\
\text { smear/dpm }\end{array}$ & $\begin{array}{l}\text { Beta- } \\
\text { Gamma } \\
\text { probe }\end{array}$ & $\begin{array}{l}\text { Beta- } \\
\text { Gamma } \\
\text { DPM }\end{array}$ & $\begin{array}{l}\text { Beta- } \\
\text { Gamma } \\
\text { smear/dpm }\end{array}$ \\
\hline \multirow[t]{5}{*}{1} & 1 & 45,000 & 25,000 & 864 & 20,000 & 200,000 & $<1,000$ \\
\hline & 2 & 35,000 & 175,000 & 370 & 22,000 & 220,000 & \\
\hline & 3 & 5,000 & 25,000 & 247 & 350 & 3,500 & \\
\hline & 4 & 1,000 & 5,000 & 247 & 400 & $4, \infty 00$ & \\
\hline & 5 & 200 & 1,000 & 370 & 40 & 400 & \\
\hline \multirow[t]{6}{*}{2} & 1 & 2,500 & 12,300 & 494 & 1800 & $18, \infty \infty$ & \\
\hline & 2 & 70,000 & 350,000 & 988 & 33,000 & 330,000 & \\
\hline & 3 & 70,000 & 350,000 & $\ddot{741}$ & 30,000 & 300,000 & \\
\hline & 4 & 700 & 3500 & 247 & 60 & 600 & \\
\hline & 5 & 2500 & 12,500 & 247 & 120 & 12,000 & \\
\hline & 6 & 600 & 3,000 & 247 & 40 & 400 & \\
\hline \multirow[t]{5}{*}{3} & 1 & 30,000 & 150,000 & 370 & 18,000 & 180,000 & \\
\hline & 2 & 170,000 & 850,000 & 494 & 23,000 & 230,000 & \\
\hline & 3 & 60,000 & 300,000 & 370 & 20,000 & 200,000 & \\
\hline & 4 & 3500 & 17,500 & 247 & 600 & 6,000 & \\
\hline & 5 & 2000 & 10,000 & 247 & 14,000 & $140, \infty 00$ & \\
\hline \multirow[t]{6}{*}{4} & 1 & 20,000 & 100,000 & 493 & 5,000 & 50,000 & \\
\hline & 2 & 45,000 & 225,000 & 247 & 12,000 & 120,000 & \\
\hline & 3 & 12,000 & 69000 & 247 & 100 & 1,000 & \\
\hline & 4 & 2,000 & 10,000 & 247 & 600 & 6,000 & \\
\hline & 5 & 300 & 1,500 & 494 & 100 & 1,000 & \\
\hline & 6 & 100 & 500 & 247 & 20 & 200 & \\
\hline \multirow[t]{5}{*}{5} & 1 & 30,000 & 150,000 & 988 & 10.000 & 100,000 & \\
\hline & 2 & 50,000 & 250,000 & $2+69$ & 23,000 & 220,000 & \\
\hline & 3 & 2,000 & 10,000 & 741 & $* \quad 250$ & 2,500 & \\
\hline & 4 & 100 & 500 & 123 & $\leq B K G$ & $\leq B K G$ & \\
\hline & 5 & 600 & 3000 & 247 & $\leq B K G$ & $\leq B K G$ & - \\
\hline \multirow[t]{7}{*}{6} & 1 & 7,000 & 35,000 & 494 & 600 & $6, \infty \infty$ & \\
\hline & 2 & 12,000 & 60,000 & 247 & 5,000 & 50,000 & \\
\hline & 3 & 10,000 & 50.000 & 370 & 4200 & 42,000 & \\
\hline & 4 & 300 & 1500 & 247 & 100 & 1,000 & \\
\hline & 5 & 50 & 250 & 247 & 40 & 400 & $\downarrow$ \\
\hline & 6 & 150 & . 750 & 123 & 40 & 400 & $<1,000$ \\
\hline & & & - & & & & \\
\hline
\end{tabular}

Fig. B8 (continued) 
warl East

$$
\begin{aligned}
& \text { * on metar } \\
& (\rho, p e \text { ol bolt })
\end{aligned}
$$

\begin{tabular}{|c|c|c|c|c|c|c|c|}
\hline row: & blk" & $\begin{array}{l}\text { Alpha } \\
\text { probe } \\
\text { cpm }\end{array}$ & $\begin{array}{l}\text { Alpha } \\
\text { DPM }\end{array}$ & $\begin{array}{l}\text { Alpha } \\
\text { smear/dpm }\end{array}$ & $\begin{array}{l}\text { Beta- } \\
\text { Gamma } \\
\text { probe }\end{array}$ & $\begin{array}{l}\text { Beta- } \\
\text { Gamma } \\
\text { DPM } \\
\end{array}$ & $\begin{array}{l}\text { Beta- } \\
\text { Gamma } \\
\text { smear/dpm }\end{array}$ \\
\hline \multirow[t]{5}{*}{7} & $L$ & 3300 & 16,500 & 741 & 1,000 & 10,000 & $<1,000$ \\
\hline & 2 & 15,000 & 75,000 & 1481 & 70,000 & 700,000 & $\uparrow$ \\
\hline & 3 & 18,000 & 90,000 & 494 & 5500 & 55,000 & \\
\hline & 4 & 100 & 500 & 494 & 40 & 400 & \\
\hline & 5 & 60 & 300 & 0 & 4.0 & 400 & \\
\hline \multirow[t]{6}{*}{8} & 1 & 1,500 & 7.500 & 247 & 100 & 1,000 & \\
\hline & 2 & 9,000 & 45,000 & 1235 & 4500 & 45,000 & \\
\hline & 3 & 5,000 & 25.000 & 617 & 2000 & 20,000 & \\
\hline & 4 & $\varnothing$ & 0 & 247 & $\leq B K G$ & $\leq B K G$ & \\
\hline & 5 & 300 & 1500 & 123 & $\leq B K G$ & $\leq B K G$ & $\downarrow$ \\
\hline & 6 & 300 & 1500 & 123 & $\leq B K G$ & $\leq B K G$ & 4,000 \\
\hline & & & & & & & \\
\hline & & & & & & & \\
\hline & & & & & & & \\
\hline & & & & & & & \\
\hline & & & & & & & \\
\hline & & & & & & & \\
\hline & & & & & & & \\
\hline & & & & & & & \\
\hline & & & & & & & \\
\hline & & & & & & & \\
\hline & & & & & & & \\
\hline & & & & & & & \\
\hline & & & & & & & \\
\hline & & & & & & & \\
\hline & & & & & & & - \\
\hline & & & & & & & \\
\hline 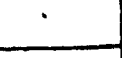 & & & & & & & \\
\hline & & & & & & & \\
\hline & & & & & & & \\
\hline & & & & & & & \\
\hline & & & & & & & \\
\hline & & & & & & & \\
\hline & & & & & & & \\
\hline
\end{tabular}

Fig. B8. (continued) 
WALL EAST * metar lbolt or pipe)

\begin{tabular}{|c|c|c|c|c|c|c|c|}
\hline row"l & blk* & $\begin{array}{l}\text { Alpha } \\
\text { probe }\end{array}$ & $\begin{array}{l}\text { Alpha } \\
\text { DPM }\end{array}$ & $\begin{array}{l}\text { Alpha } \\
\text { smear/dpm }\end{array}$ & $\begin{array}{l}\text { Beta- } \\
\text { Gamma } \\
\text { probe }\end{array}$ & $\begin{array}{l}\text { Beta- } \\
\text { Gamma } \\
\text { DPM }\end{array}$ & $\begin{array}{l}\text { Beta- } \\
\text { Gamma } \\
\text { smear/dpp }\end{array}$ \\
\hline \multirow[t]{5}{*}{9} & 1 & 400 & 2000 & 50 & $\leq B K G$ & $\leq B K G$ & $\leq B K G$ \\
\hline & 2 & 2000 & 10,000 & 300 & 450 & 4500 & 木 \\
\hline & 3 & 2700 & 13,500 & 0 & 200 & 2000 & \\
\hline & 4 & 100 & 500 & 0 & $\leq B K G$ & $\leqslant B K G$ & \\
\hline & 5 & 100 & 500 & 0 & 1 & $I$ & \\
\hline \multirow[t]{6}{*}{10} & 1 & 100 & 500 & 0 & 50 & 500 & \\
\hline & 2 & 1000 & 5,000 & 300 & 200 & 2,000 & \\
\hline & 3 & 800 & 4,000 & 0 & $\leq B K G$ & $\leqslant 8 K 4$ & \\
\hline & 4 & 50 & 250 & 0 & 不 & 1 & \\
\hline & 5 & 60 & 300 & 0 & & & \\
\hline & 6 & 130 & 650 & 0 & $\downarrow$ & $\downarrow$ & \\
\hline \multirow[t]{5}{*}{11} & 1 & 5,000 & 25,000 & 0 & 800 & 8,000 & \\
\hline & 2 & 700 & 3500 & 0 & 200 & 2,000 & \\
\hline & 3 & 40 & 200 & 0 & $\leq B K G$ & $\leq B K G$ & \\
\hline & 4 & 20 & 100 & 0 & & $\uparrow$ & \\
\hline & 5 & 40 & 200 & 0 & & & \\
\hline \multirow[t]{6}{*}{12} & 1 & 400 & 2,000 & 0 & $\downarrow$ & $k$ & \\
\hline & 2 & 700 & 3500 & 0 & 150 & 1500 & \\
\hline & 3 & 150 & 750 & 0 & $\leq B K G$ & $\leq B K G$ & \\
\hline & 4 & 20 & 100 & 0 & & & \\
\hline & 5 & 10 & 50 & 0 & & & \\
\hline & 6 & 10 & 50 & 0 & $\sqrt{k}$ & $\downarrow$ & \\
\hline \multirow[t]{5}{*}{13} & 1 & 400 & 2000 & 0 & 100 & 1000 & \\
\hline & 2 & 1000 & 5,000 & 0 & $\leq B K G$ & $\leqslant B K G$ & \\
\hline & 3 & 10 & 50 & 0 & $* 100$ & 1000 & \\
\hline & 4 & 200 & 1000 & 0 & $\leq B K G$ & $\leq B K G$ & \\
\hline & 5 & 40 & 200 & 0 & 70 & 700 & \\
\hline \multirow[t]{6}{*}{14} & 1 & 10 & 50 & 0 & $\leq B K G$ & $S B K G$ & \\
\hline & 2 & 600 & 3000 & 0 & 250 & 2500 & $\downarrow$ \\
\hline & 3 & 40 & 200 & 0 & 50 & 500 & $\leq B K G$ \\
\hline & 4 & 20 & 100 & 0 & $\leq B K G$ & $\leq B K G$ & \\
\hline & 5 & 40 & 20 & 0 & 䄳 & 5 & $x$ \\
\hline & 6 & 10 & 50 & 0 & $\leq B \times G$ & $\leq B K G$ & $\leq B K G$ \\
\hline & & & & & & & \\
\hline & & & & & & & \\
\hline
\end{tabular}

Fig. B.8. (continued) 
wall EAst * mette (bolt or Pipe)

\begin{tabular}{|c|c|c|c|c|c|c|c|}
\hline row" & blk & $\begin{array}{l}\text { Alpha } \\
\text { probe }\end{array}$ & $\begin{array}{l}\text { Alpha } \\
\text { DPM }\end{array}$ & $\begin{array}{l}\text { Alpha } \\
\text { smear/dpm }\end{array}$ & $\begin{array}{l}\text { Beta- } \\
\text { Gamma } \\
\text { probe }\end{array}$ & $\begin{array}{l}\text { Beta- } \\
\text { Gamma } \\
\text { DPM }\end{array}$ & $\begin{array}{l}\text { Beta- } \\
\text { Gamma } \\
\text { smear/dpm }\end{array}$ \\
\hline \multirow[t]{7}{*}{15} & 1 & 500 & 2500 & 0 & $\leq B \times 4$ & $\leq B K G$ & $\leqslant B K G$ \\
\hline & 2 & 2800 & 14,000 & 0 & 600 & 6000 & $\pi$ \\
\hline & 3 & 30 & 150 & 0 & $\leq B K G$ & $\leq 8 \times 4$ & \\
\hline & 4 & 20 & 100 & 0 & 本 & 不 & \\
\hline & 5 & 30 & 150 & 0 & & & \\
\hline & 6 & 20 & 100 & 0 & & & \\
\hline & 7 & 100 & 500 & 0 & & & \\
\hline \multirow[t]{8}{*}{16} & 1 & 50 & 250 & 0 & & & \\
\hline & 2 & 200 & 1000 & 0 & & & \\
\hline & 3 & 40 & 200 & 0 & & & \\
\hline & 4 & 60 & 300 & 0 & & & \\
\hline & 5 & 20 & 100 & 0 & & & \\
\hline & 6 & 20 & 100 & 0 & & & \\
\hline & 7 & 20 & 100 & 0 & & & \\
\hline & 8 & 180 & 900 & 0 & & & \\
\hline \multirow[t]{7}{*}{17} & 1 & 20 & 100 & 0 & & & \\
\hline & 2 & 20 & 100 & 0 & & & \\
\hline & 3 & 20 & 100 & 0 & & & \\
\hline & 4 & 20 & 100 & 0 & & & \\
\hline & 5 & 2 & 100 & 0 & & & \\
\hline & 6 & 0 & 0 & 0 & & & \\
\hline & 7 & 20 & 100 & 0 & & & \\
\hline \multirow[t]{12}{*}{18} & 1 & 50 & 250 & 0 & & & \\
\hline & 2 & 500 & 2500 & 100 & & & \\
\hline & 3 & 20 & 100 & 0 & & & \\
\hline & 4 & 50 & 250 & 0 & & & \\
\hline & 5 & 0 & 0 & 0 & & & - \\
\hline & 6 & 50 & 250 & 0 & & & \\
\hline & 7 & 0 & 0 & 0 & $v$ & $k$ & $\downarrow$ \\
\hline & 8 & 0 & 0 & 0 & $\leq B \times G$ & $\leq B K G$ & $\leq B K G$ \\
\hline & & & & & & & \\
\hline & & & & & & & \\
\hline & & & & & & & \\
\hline & & & & & & & \\
\hline
\end{tabular}

Fig. B.8. (continued) 
wall EAst * Metal (BOLT or Pipe)

\begin{tabular}{|c|c|c|c|c|c|c|c|}
\hline row" & blk: & $\begin{array}{l}\text { Alpha } \\
\text { probe }\end{array}$ & $\begin{array}{l}\text { Alpha } \\
\text { DPM }\end{array}$ & $\begin{array}{l}\text { Alpha } \\
\text { smear/dpm }\end{array}$ & $\begin{array}{l}\text { Beta- } \\
\text { Gamma } \\
\text { probe }\end{array}$ & $\begin{array}{l}\text { Beta- } \\
\text { Gamma } \\
\text { DPM }\end{array}$ & $\begin{array}{l}\text { Beta- } \\
\text { Gamma } \\
\text { smear/dpm }\end{array}$ \\
\hline \multirow[t]{7}{*}{19} & 1 & 200 & 1000 & 0 & 10 & 100 & $\leq B K L$ \\
\hline & 2 & 150 & 750 & 0 & $\leq B 6 G$ & $\leq B \times G$ & 1 \\
\hline & 3 & 20 & 100 & 0 & $\leq B \times G$ & $\leq B K G$ & \\
\hline & 4 & 20 & 100 & 0 & 20 & 200 & \\
\hline & 5 & 0 & 0 & 0 & \multirow{2}{*}{$\leq B_{K G}$} & $\leq B K G$ & \\
\hline & 6 & 40 & 200 & 0 & & T & \\
\hline & 7 & 0 & 0 & 0 & & & \\
\hline \multirow[t]{8}{*}{20} & 1 & 30 & 150 & 0 & & & \\
\hline & 2 & 100 & 500 & 0 & & & \\
\hline & 3 & 20 & 100 & 0 & \multirow{2}{*}{$\frac{k}{30}$} & $\frac{d}{200}$ & \\
\hline & 4 & 10 & 50 & 0 & & 300 & \\
\hline & 5 & 70 & 350 & 0 & 20 & 200 & \\
\hline & 6 & 10 & 50 & 0 & $\leq B \times G$ & $\leqslant B K G$ & \\
\hline & 7 & 20 & 100 & 0 & & & \\
\hline & 8 & 0 & 0 & 0 & & & \\
\hline 21 & 1 & 10 & 50 & 0 & & & \\
\hline & 2 & 40 & 200 & 0 & & & \\
\hline & 3 & 30 & 150 & 0 & & & \\
\hline & 4 & 30 & 150 & 0 & & & \\
\hline & 5 & 10 & 50 & 0 & & & \\
\hline & 6 & 10 & 50 & 0 & & & \\
\hline & 7 & 20 & 100 & 0 & & & \\
\hline 22 & 1 & 0 & 0 & 0 & & & \\
\hline & 2 & 10 & 50 & 0 & & & \\
\hline & 3 & 20 & 100 & 0 & & & \\
\hline & 4 & * 20 & 100 & 0 & & & \\
\hline & 5 & 30 & 150 & 0 & & & \\
\hline & 6 & 20 & 100 & 0 & & & \\
\hline & 7 & $* 20$ & 100 & 0 & L & $\downarrow$ & $\sqrt{ }$ \\
\hline & 8 & 20 & 100 & 0 & $\leq B \times G$ & $\leq 8 K G$ & $\sum B K G$ \\
\hline & & & & & & & \\
\hline & & & & & & & \\
\hline & & & & & & & \\
\hline & & & & & & & \\
\hline & & & & & & & \\
\hline
\end{tabular}

Fig. B\& (continued) 


\section{B-31}

WALL EAST

* metar (boct or pipe)

\begin{tabular}{|c|c|c|c|c|c|c|c|}
\hline row & blki & $\begin{array}{l}\text { Alpha } \\
\text { probe }\end{array}$ & $\begin{array}{l}\text { Alpha } \\
\text { DPM }\end{array}$ & $\begin{array}{l}\text { Alpha } \\
\text { smear/dpw }\end{array}$ & $\begin{array}{l}\text { Beta- } \\
\text { Gamma } \\
\text { probe } \\
\end{array}$ & $\begin{array}{l}\text { Beta- } \\
\text { Gamma } \\
\text { DPM } \\
\end{array}$ & $\begin{array}{l}\text { Beta- } \\
\text { Gamma } \\
\text { smear/dpm }\end{array}$ \\
\hline \multirow[t]{7}{*}{23} & 1 & $* 50$ & 250 & 0 & $* 100$ & 1000 & $\leq B K G$ \\
\hline & 2 & 30 & 150 & 0 & $\leq B K C$ & $\leq B \times G$ & 1 \\
\hline & 3 & 30 & 150 & 0 & $\pi$ & 1 & \\
\hline & 4 & 20 & 100 & 0 & & & \\
\hline & 5 & $* 30$ & 150 & 0 & & & \\
\hline & 6 & 30 & 150 & 0 & $\downarrow$ & $k$ & \\
\hline & 7 & $* 30$ & 150 & 0 & $* 50$ & 500 & \\
\hline \multirow[t]{8}{*}{24} & 1 & 10 & 50 & 2 & $\leq B K G$ & $\leq 8 K G$ & \\
\hline & 2 & 30 & 150 & 0 & 1 & 7 & \\
\hline & 3 & 20 & 100 & 0 & $x$ & $\sqrt{k}$ & \\
\hline & 4 & 30 & 150 & 0 & 50 & 500 & \\
\hline & 5 & 30 & 150 & 0 & 50 & 500 & \\
\hline & 6 & 10 & 50 & 0 & $\leq B K G$ & $\leq B \times L$ & \\
\hline & 7 & 10 & 50 & 0 & 50 & 500 & \\
\hline & 8 & 10 & 50 & 0 & $\leq B \times G$ & $\leq B A G$ & \\
\hline \multirow[t]{7}{*}{25} & 1 & 150 & 750 & 0 & $\leq B K G$ & $\leq 8 k 6$ & \\
\hline & 2 & 40 & 200 & 0 & 50 & 500 & \\
\hline & 3 & 20 & 100 & 0 & $\leq 66 G$ & $\leq B K G$ & \\
\hline & 4 & 20 & 100 & 0 & 100 & 1000 & \\
\hline & 5 & 30 & 150 & 0 & 50 & 500 & \\
\hline & 6 & 30 & 150 & 0 & 50 & 500 & $k$ \\
\hline & 7 & 20 & 100 & 0 & 50 & 500 & $\leq B K G$ \\
\hline & & & & & & & \\
\hline & & & & & & & \\
\hline & & & & & & & \\
\hline & & & & & & & - \\
\hline & & & & & & & \\
\hline & & & & & & & \\
\hline & & & & $\therefore$ & & & \\
\hline & & & & & & & \\
\hline & & & & & & & \\
\hline & & & & & & & \\
\hline & & & & & & & \\
\hline
\end{tabular}

Fiz B8 (continued) 
WALL SOUTH

\begin{tabular}{|c|c|c|c|c|c|c|c|}
\hline row 1 & blkt & $\begin{array}{l}\text { Alpha } \\
\text { probe } \\
\text { can }\end{array}$ & $\begin{array}{l}\text { Alpha } \\
\text { DPM }\end{array}$ & $\begin{array}{l}\text { Alpha } \\
\text { smear/dpm }\end{array}$ & $\begin{array}{l}\text { Beta- } \\
\text { Gamma } \\
\text { probe }\end{array}$ & $\begin{array}{l}\text { Beta- } \\
\text { Gamma } \\
\text { DPM }\end{array}$ & $\begin{array}{l}\text { Beta- } \\
\text { Gamma } \\
\text { smear/dpr }\end{array}$ \\
\hline$L$ & 1 & 1.100 & 5,500 & 0 & 1,000 & 10,000 & 11,000 \\
\hline & 2 & 17,000 & 85,000 & 100 & 40 & $4 \infty$ & $\uparrow$ \\
\hline & 3 & 600 & 3.000 & 50 & 60 & 600 & \\
\hline 2 & 1 & 50 & 250 & 0 & 40 & 40 & \\
\hline & 2 & 50 & 250 & 0 & 40 & 400 & \\
\hline 3 & 1 & 400 & 2,000 & 50 & 200 & 2,000 & \\
\hline & 2 & 250 & 1250 & 50 & 60 & 600 & \\
\hline & 3 & 250 & 1250 & 0 & 150 & 1,500 & \\
\hline 4 & 1 & 100 & 500 & 0 & 60 & 600 & \\
\hline & 2 & 80 & 400 & 0 & 40 & 40 & \\
\hline 5 & 1 & 50 & 250 & 100 & 20 & 200 & \\
\hline & 2 & 20 & 100 & 0 & 50 & 500 & \\
\hline & 3 & $\theta$ & 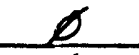 & 0 & 20 & 200 & \\
\hline 6 & 1 & $\mathscr{Q}$ & $\varnothing$ & 0 & $\leq B k 4$ & $\leq 8 K G$ & \\
\hline & 2 & 30 & 150 & 50 & $\leq B K L$ & $\leq 8 K G$ & \\
\hline 7 & 1 & 20 & 100 & 50 & $\leq B K G$ & $\leq B K G$ & \\
\hline & 2 & 20 & 100 & 50 & $\leq B K G$ & $\leq B K G$ & \\
\hline & 3 & $\phi$ & $\mathscr{P}$ & 0 & $\leq B \times G$ & $\leq B K G$ & \\
\hline 8 & 1 & $\theta$ & $\mathscr{Q}$ & 0 & 50 & 500 & $t$ \\
\hline & 2 & 2 & 2 & 0 & $\leq G K G$ & $\leq B K G$ & $<1,000$ \\
\hline & & & & & & & \\
\hline & & & & & & & \\
\hline & & & & & & & \\
\hline & & & & & & & \\
\hline & & & & & & & \\
\hline & & & & & & & \\
\hline & & & & & & & \\
\hline & & & & & & & \\
\hline & & & & & & & \\
\hline & & & • & & & & \\
\hline & & & & & & & \\
\hline & & & & & & & \\
\hline
\end{tabular}

Fig. B.8. (continued) 
PACS 15 OF 24

WALL SouTH

* metal (aolt on pipd)

\begin{tabular}{|c|c|c|c|c|c|c|c|}
\hline row & blkt & $\begin{array}{l}\text { Alpha } \\
\text { probe }\end{array}$ & $\begin{array}{l}\text { Alpha } \\
\text { DPM }\end{array}$ & $\begin{array}{l}\text { Alpha } \\
\text { smear/dpm }\end{array}$ & $\begin{array}{l}\text { Beta- } \\
\text { Gamma } \\
\text { probe } \\
\end{array}$ & $\begin{array}{l}\text { Beta- } \\
\text { Gamma } \\
\text { DPM }\end{array}$ & $\begin{array}{l}\text { Beta- } \\
\text { Gamma } \\
\text { smear/dpm }\end{array}$ \\
\hline \multirow[t]{3}{*}{9} & 1 & 10 & 50 & 0 & $\leq 8 \mathrm{~kg}$ & $\leq \mathrm{BKG}$ & $\therefore B K G$ \\
\hline & 2 & 30 & 150 & 0 & & & \\
\hline & 3 & 10 & 50 & 0 & & & \\
\hline \multirow[t]{2}{*}{10} & 1 & 10 & 50 & o. & & & \\
\hline & 2 & 120 & 600 & 0 & & & \\
\hline \multirow[t]{5}{*}{11} & 1 & 20 & 100 & 0 & & & \\
\hline & 2 & 20 & 100 & 0 & & & \\
\hline & 3 & 30 & 150 & 0 & & & \\
\hline & 4 & 30 & 150 & 0 & & & \\
\hline & 5 & 50 & 250 & 0 & & & \\
\hline \multirow[t]{5}{*}{12} & 1 & 20 & 100 & 0 & & & \\
\hline & 2 & 20 & 100 & 0 & & & \\
\hline & 3 & 40 & 200 & 0 & & & \\
\hline & 4 & 50 & 250 & 0 & & & \\
\hline & 5 & 10 & 50 & 0 & & & \\
\hline \multirow[t]{5}{*}{13} & 1 & 50 & 250 & 0 & & & \\
\hline & 2 & 50 & 250 & 0 & & & \\
\hline & 3 & 150 & 750 & 0 & & & \\
\hline & 4 & 50 & 250 & 0 & & & \\
\hline & 5 & 20 & 100 & 0 & & & \\
\hline \multirow[t]{5}{*}{14} & 1 & 10 & 50 & 0 & & & \\
\hline & 2 & 20 & 100 & 0 & & & \\
\hline & 3 & 40 & 200 & 0 & & & \\
\hline & 4 & 40 & 200 & 0 & & & \\
\hline & 5 & 20 & 100 & 0 & & & \\
\hline \multirow[t]{10}{*}{15} & 1 & to & 200 & 0 & & & \\
\hline & 2 & 20 & 100 & 0 & & & \\
\hline & 3 & 20 & 100 & 0 & & & \\
\hline & 4 & 40 & 200 & 0 & & & \\
\hline & 5 & 20 & 100 & 0 & & & \\
\hline & 6 & 20 & 100 & 0 & $\sqrt{2}$ & $s$ & $\downarrow$ \\
\hline & 7 & 20 & 100 & 0 & $\leq B K G$ & $\leq B K G$ & $\leq B K G$ \\
\hline & & & - & & & & \\
\hline & & & & & & & \\
\hline & & & & & & & \\
\hline
\end{tabular}

Fig B.8 (continued) 
WALL Soutrt

* Metal (BoLt on Pire)

\begin{tabular}{|c|c|c|c|c|c|c|c|}
\hline row" & blk & $\begin{array}{l}\text { Alpha } \\
\text { probe }\end{array}$ & $\begin{array}{l}\text { Alpha } \\
\text { DPM }\end{array}$ & $\begin{array}{l}\text { Alpha } \\
\text { smear/dpm }\end{array}$ & $\begin{array}{l}\text { Beta- } \\
\text { Gamma } \\
\text { probe }\end{array}$ & $\begin{array}{l}\text { Beta- } \\
\text { Gamma } \\
\text { DPM }\end{array}$ & $\begin{array}{l}\text { Beta- } \\
\text { Gamma } \\
\text { smear/dpm }\end{array}$ \\
\hline \multirow[t]{6}{*}{16} & 1 & 20 & 100 & 0 & $\leqslant B K G$ & $\leq 8 K G$ & $\leq B K G$ \\
\hline & 2 & 20 & 100 & 0 & & & 1 \\
\hline & 3 & 20 & 100 & 0 & & & \\
\hline & 4 & 20 & 100 & 0 & & & \\
\hline & 5 & 20 & 100 & 0 & & & \\
\hline & 6 & 20 & 100 & 0 & & & \\
\hline \multirow[t]{7}{*}{17} & 1 & 20 & 100 & 0 & & & \\
\hline & 2 & 40 & 200 & 0 & $x$ & & \\
\hline & 3 & 20 & 100 & 0 & $\leq B K G$ & $\leq E K G$ & $\leq B K G$ \\
\hline & 4 & 20 & 100 & 0 & 50 & 500 & $\uparrow$ \\
\hline & 5 & 20 & 100 & 0 & $\leq B K G$ & $\leq B K G$ & \\
\hline & 6 & 20 & 100 & 0 & & $\uparrow$ & \\
\hline & 7 & 20 & 100 & 0 & & & \\
\hline \multirow[t]{6}{*}{18} & 1 & 20 & 100 & 0 & & & \\
\hline & 2 & 20 & 100 & 0 & & & \\
\hline & 3 & 20 & 100 & 0 & & & \\
\hline & 4 & 40 & 200 & 0 & & & \\
\hline & 5 & 20 & 100 & 0 & & & \\
\hline & 6 & 20 & 100 & 0 & & & \\
\hline \multirow[t]{7}{*}{19} & 1 & 20 & 100 & 0 & & & \\
\hline & 2 & 20 & 100 & 0 & & & \\
\hline & 3 & 20 & 100 & 0 & & & \\
\hline & 4 & 20 & 100 & 0 & & & \\
\hline & 5 & 20 & 100 & 0 & & & \\
\hline & 6 & 20 & 100 & 0 & & & \\
\hline & 1 & 20 & 100 & 0 & & & \\
\hline \multirow[t]{8}{*}{20} & 1 & 20 & 100 & 0 & & & \\
\hline & 2 & 20 & 100 & 0 & & & \\
\hline & 3 & 20 & 100 & 0 & & & \\
\hline & 4 & 20 & 100 & 0 & & & \\
\hline & 5 & 20 & 100 & 0 & $t$ & $\downarrow$ & $\downarrow$ \\
\hline & 6 & 20 & 100 & 0 & $\leq B K G$ & $\leq B K G$ & $\leq B K G$ \\
\hline & & & - & & & & \\
\hline & & & & & & & \\
\hline & & & & & & & \\
\hline
\end{tabular}

Fig. B8. (continued) 


\begin{tabular}{|c|c|c|c|c|c|c|c|}
\hline row & blkt & $\begin{array}{l}\text { Alpha } \\
\text { probe }\end{array}$ & $\begin{array}{l}\text { Alpha } \\
\text { DPM }\end{array}$ & $\begin{array}{l}\text { Alpha } \\
\text { smear/dpm }\end{array}$ & $\begin{array}{l}\text { Beta- } \\
\text { Gamma } \\
\text { probe }\end{array}$ & $\begin{array}{l}\text { Bets- } \\
\text { Gamma } \\
\text { DPM }\end{array}$ & $\begin{array}{l}\text { Beta- } \\
\text { Gamma } \\
\text { smear/dpm }\end{array}$ \\
\hline \multirow[t]{7}{*}{21} & 1 & 20 & 100 & 0 & $\leq B K G$ & $\leq B K G$ & $\leq B K G$ \\
\hline & 2 & 20 & 100 & 0 & $\leq B K G$ & $\leq B K G$ & $\leq B K G$ \\
\hline & 3 & 20 & 100 & 0 & 100 & 1,000 & \\
\hline & 4 & 40 & 200 & 0 & $\leq B K G$ & $\leq B K G$ & \\
\hline & 5 & 20 & 100 & 0 & & & \\
\hline & 6 & 20 & 100 & 0 & & & \\
\hline & 2 & 20 & 100 & 50 & & & \\
\hline \multirow[t]{6}{*}{22} & 1 & 20 & 100 & 0 & -1 & 1 & \\
\hline & 2 & 20 & 100 & 0 & $\leq B K G$ & $\leq B K G$ & \\
\hline & 3 & 40 & $2 \infty$ & 0 & 50 & 500 & \\
\hline & 4 & 20 & 100 & 0 & 50 & 500 & \\
\hline & 5 & 20 & 100 & 0 & $\leq B K G$ & $\leq 8 \mathrm{KG}$ & \\
\hline & 6 & $\div 400$ & 2,000 & 0 & $\approx 400$ & 4,000 & \\
\hline \multirow[t]{7}{*}{23} & 1 & 0 & 0 & 0 & $\leq B K G$ & $\leq 8 K G$ & \\
\hline & 2 & 0 & 0 & 0 & & 9 & \\
\hline & 3 & 20 & 100 & 0 & & & \\
\hline & 4 & 0 & 0 & 0 & 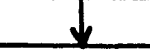 & $\sqrt{2}$ & \\
\hline & 5 & 20 & 100 & 250 & $\leq B K G$ & $\leq B K G$ & \\
\hline & 6 & 10 & 50 & 0 & 50 & 500 & \\
\hline & 7 & 10 & 50 & 0 & 50 & 500 & \\
\hline \multirow[t]{6}{*}{24} & 1 & 0 & 0 & 0 & $\leq$ BKS & $\leq B K F$ & \\
\hline & 2 & 0 & 0 & 0 & 50 & 500 & \\
\hline & 3 & 0 & 0 & 0 & $\leq B K G$ & $\leq B K G$ & \\
\hline & 4 & 20 & 100 & 0 & $\leq 8 K G$ & $\leq \mathrm{BKG}$ & \\
\hline & 5 & 20 & 100 & 100 & 50 & 500 & \\
\hline & 6 & 30 & 150 & 0 & $\leq B K G$ & $\leq B K G$ & \\
\hline \multirow[t]{9}{*}{25} & 1 & 20 & 100 & 0 & 250 & 2,500 & - \\
\hline & 2 & 50 & 250 & 0 & 200 & $2, \infty \infty$ & \\
\hline & 3 & 20 & 100 & 0 & 100 & 1,000 & \\
\hline & 4 & 100 & 500 & $0:$ & 50 & 500 & \\
\hline & 5 & 50 & 250 & 0 & 50 & 520 & \\
\hline & 6 & 20 & 100 & 0 & $\leq B K G$ & E BKG & $t$ \\
\hline & 1 & 40 & 200 & 0 & 50 & 500 & $\angle B K G$ \\
\hline & & & - & - & & & \\
\hline & & & & & & & \\
\hline
\end{tabular}

Fig. B.8 (continued) 
waLL West

* On metar

PACE 18 OF 24

(Piref on Rerer)

\begin{tabular}{|c|c|c|c|c|c|c|c|}
\hline row & blkt & $\begin{array}{l}\text { Alpha } \\
\text { probe } \\
\text { CPM }\end{array}$ & $\begin{array}{l}\text { Alpha } \\
\text { DPM }\end{array}$ & $\begin{array}{l}\text { Alpha } \\
\text { smear/dpm }\end{array}$ & $\begin{array}{l}\text { Beta- } \\
\text { Gamma } \\
\text { probe }\end{array}$ & $\begin{array}{l}\text { Beta- } \\
\text { Gamma } \\
\text { DPM }\end{array}$ & $\begin{array}{l}\text { Beta- } \\
\text { Gamma } \\
\text { smear/dpm }\end{array}$ \\
\hline \multirow[t]{7}{*}{1} & 1 & 2,000 & $10, \infty \infty$ & 0 & $* 1,000$ & 10,000 & $<1,000$ \\
\hline & 2 & 1,000 & 5,000 & 0 & 1,800 & 18,000 & \\
\hline & 3 & 500 & 2,500 & 50 & $1, \infty 0$ & $10, \infty 00$ & \\
\hline & 4 & 20,000 & $100, \infty \infty$ & 100 & 5,000 & 50,000 & \\
\hline & 5 & 4,000 & $20, \infty 00$ & 100 & 1,500 & 15,000 & \\
\hline & 6 & 3,000 & 15,000 & 50 & 1,800 & 18,000 & \\
\hline & 7 & 25,000 & 125,000 & 1,500 & 22,000 & $220, \infty 0$ & \\
\hline \multirow[t]{8}{*}{2} & 1 & 200 & 1,000 & 50 & 40 & $+\infty$ & \\
\hline & 2 & 200 & 1,000 & 0 & 40 & 400 & \\
\hline & 3 & 500 & 2,500 & 0 & 300 & 3,00 & \\
\hline & 4 & 2,500 & 12,500 & 50 & $2, \infty \infty$ & 20,000 & \\
\hline & 5 & 10,000 & 50,000 & 250 & $5, \infty 00$ & $50, \infty 0$ & \\
\hline & 6 & $2, \infty \infty$ & $10,0 \infty$ & 100 & 1,500 & 15,000 & \\
\hline & 7 & 5,000 & 25,000 & 100 & 2,200 & 22,000 & \\
\hline & 8 & 3,500 & 17,500 & 500 & 10,000 & 100,000 & \\
\hline \multirow[t]{7}{*}{3} & 1 & 200 & 1,000 & 50 & 50 & 500 & \\
\hline & 2 & 450 & 2,250 & 0 & 250 & 2,500 & \\
\hline & 3 & 450 & 2,250 & 0 & 50 & 500 & \\
\hline & 4 & 200 & 1,000 & 0 & 50 & 500 & \\
\hline & 5 & 3,000 & 15,000 & 50 & 900 & $9, \infty 00$ & \\
\hline & 6 & 0,000 & $30, \infty 00$ & 50 & 1,200 & 12,000 & \\
\hline & 7 & 14,000 & 70,000 & 250 & 3,000 & 30,000 & \\
\hline \multirow[t]{13}{*}{4} & 1 & 100 & $5 \infty$ & 50 & 50 & 500 & \\
\hline & 2 & 80 & 400 & 50 & 20 & 200 & \\
\hline & 3. & 600 & 3,000 & 0 & 50 & 500 & \\
\hline & 't & 600 & 3,000 & 50 & 150 & 1,500 & \\
\hline & 5 & 1,200 & 6,000 & 50 & 600 & $6, \infty \infty$ & - \\
\hline & 6 & 600 & 3,000 & 50 & 200 & 2,000 & \\
\hline & 7 & 2,200 & 1,000 & 은 & $4 \infty$ & 4,000 & 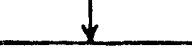 \\
\hline & 8 & 2,500 & 12,500 & 150 & 2,000 & 20,000 & $<1,000$ \\
\hline & & & & & & & \\
\hline & & & & & & & \\
\hline & & & - & & & & \\
\hline & & & & & & & \\
\hline & & & & & & & \\
\hline
\end{tabular}

Fig. B.8 (continued) 
wald West

* ON metal

\begin{tabular}{|c|c|c|c|c|c|c|c|}
\hline row $\$$ & blkt & $\begin{array}{c}\text { Alpha } \\
\text { probe } \\
\text { CPM }\end{array}$ & $\begin{array}{l}\text { Alpha } \\
\text { DPM }\end{array}$ & $\begin{array}{l}\text { Alpha } \\
\text { smear/dpm }\end{array}$ & $\begin{array}{l}\text { Beta- } \\
\text { Gamma } \\
\text { probe }\end{array}$ & $\begin{array}{l}\text { Beta- } \\
\text { Gamma } \\
\text { DPM } \\
\end{array}$ & $\begin{array}{l}\text { Beta- } \\
\text { Gamma } \\
\text { smear/dpm }\end{array}$ \\
\hline \multirow[t]{7}{*}{5} & 1 & 80 & 400 & 50 & 20 & 200 & $<1, \infty 00$ \\
\hline & 2 & 600 & 3,000 & 0 & 60 & 600 & $\uparrow$ \\
\hline & 3 & 100 & 500 & 0 & 60 & 600 & \\
\hline & 4 & 100 & 500 & 50 & 50 & 500 & \\
\hline & 5 & 800 & 4,000 & 0 & 100 & 1,000 & \\
\hline & 6 & 2,000 & 10,000 & 100 & 600 & 6,000 & \\
\hline & 7 & 700 & 3,500 & 50 & 80 & 800 & \\
\hline \multirow[t]{8}{*}{6} & 1 & 0 & 0 & 0 & $\leq B K G$ & $\leq B K G$ & \\
\hline & 2 & 50 & 250 & 50 & $\leq B K G$ & $\leq B K G$ & \\
\hline & 3 & 1,500 & 7, & 50 & 50 & 500 & \\
\hline & 4 & 0 & 0 & 50 & $\leq B K G$ & $\leq B K G$ & \\
\hline & 5 & 50 & 250 & 100 & $\leq B K G$ & $\leq B K G$ & \\
\hline & 6 & 1,000 & 5,000 & 150 & 500 & $5, \infty$ & \\
\hline & 7 & 600 & 3,000 & 100 & 200 & $2, \infty \infty$ & \\
\hline & 8 & 650 & 3,250 & 200 & 100 & 1,000 & \\
\hline \multirow[t]{7}{*}{7} & 1 & 50 & 250 & 50 & 40 & 400 & \\
\hline & 2 & 1,000 & 5,000 & 0 & 650 & 6,500 & \\
\hline & 3 & 0 & 0 & 0 & 40 & $+\infty$ & \\
\hline & 4 & 50 & 250 & 0 & 40 & 400 & \\
\hline & 5 & 200 & 1,000 & 50 & 40 & $4 \infty$ & \\
\hline & 6 & 400 & 2,000 & 50 & 400 & 4,000 & \\
\hline & 7 & 800 & 4,000 & 100 & 800 & 8000 & \\
\hline \multirow[t]{12}{*}{8} & 1 & 20 & 100 & 50 & 40 & 400 & \\
\hline & 2 & 50 & 250 & 0 & 40 & $+\infty$ & \\
\hline & 3 & 360 & 1,800 & 0 & 200 & 2,000 & \\
\hline & 4 & 0 & 0 & 50 & 40 & $+\infty$ & \\
\hline & 5 & 50 & 2.50 & 0 & 50 & 500 & - \\
\hline & 6 & 300 & 1,500 & 0 & 40 & 400 & \\
\hline & 7 & 800 & $4, \infty 00$ & 50 & 300 & 3,000 & $\downarrow$ \\
\hline & 8 & 4,200 & $21, \infty \infty$ & 150 & 1,500 & 15,000 & $<1, \infty$ \\
\hline & & & & & & & \\
\hline & & & $\cdot$ & & & & \\
\hline & & & - & - & & & \\
\hline & & & & & & & \\
\hline
\end{tabular}

Fig B\& (continued) 
WALL WeST * metal (Bout on Pire)

\begin{tabular}{|c|c|c|c|c|c|c|c|}
\hline row & blk & $\begin{array}{l}\text { Alpha } \\
\text { probe }\end{array}$ & $\begin{array}{l}\text { Alpha } \\
\text { DPM }\end{array}$ & $\begin{array}{l}\text { Alpha } \\
\text { smear/dpm }\end{array}$ & $\begin{array}{l}\text { Beta- } \\
\text { Gamma } \\
\text { probe }\end{array}$ & $\begin{array}{l}\text { Beta- } \\
\text { Gamma } \\
\text { DPM } \\
\end{array}$ & $\begin{array}{l}\text { Beta- } \\
\text { Gamma } \\
\text { smear/dpm }\end{array}$ \\
\hline \multirow[t]{7}{*}{9} & 1 & 60 & 300 & 100 & $\leq B K G$ & $\leq B K G$ & $\leq B K G$ \\
\hline & 2 & 1,000 & 5,000 & 0 & & & $\uparrow$ \\
\hline & 3 & 40 & 200 & 0 & & & \\
\hline & 4 & 40 & 200 & 0 & & & \\
\hline & 5 & 100 & 500 & 0 & $\sqrt{2}$ & $\downarrow$ & \\
\hline & 6 & 100 & 500 & 0 & $\leq B K G$ & $\leq 8 \mathrm{KG}$ & \\
\hline & 7 & 1,600 & 8,000 & 100 & 500 & 5,000 & \\
\hline \multirow[t]{8}{*}{10} & 1 & 40 & 200 & 0 & $\leq B K G$ & $\leq B K G$ & \\
\hline & 2 & 60 & 300 & 0 & & 1 & \\
\hline & 3 & 20 & 100 & 0 & & & \\
\hline & 4 & 20 & 100 & 0 & & & \\
\hline & 5 & 50 & 250 & 0 & & & \\
\hline & 6 & 120 & 600 & 0 & $\downarrow$ & $\downarrow$ & \\
\hline & 7 & 200 & 1,000 & 50 & $\leqslant B K G$ & $\leq B K G$ & \\
\hline & 8 & 5,000 & 25,000 & 100 & 500 & 5,000 & \\
\hline \multirow[t]{7}{*}{11} & 1 & 20 & 100 & 0 & $\leq B K G$ & SBKG & \\
\hline & 2 & 100 & 500 & 0 & 1 & & \\
\hline & 3 & 40 & 200 & 0 & & & \\
\hline & 4 & 40 & 200 & 0 & & & \\
\hline & 5 & 50 & 250 & 0 & 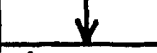 & & \\
\hline & 6 & 20 & 100 & 0 & EBKG & $\leqslant B K G$ & \\
\hline & 2 & 1,000 & 5,000 & 0 & 100 & 1,000 & \\
\hline \multirow[t]{12}{*}{12} & 1 & 20 & 100 & 0 & $\leq B K G$ & $\leq B K G$ & \\
\hline & 2 & 40 & 200 & 0 & & & \\
\hline & 3 & 300 & 1,500 & 0 & & & \\
\hline & 4 & 60 & 300 & 0 & & & \\
\hline & 5 & 40 & 200 & 0 & & & - \\
\hline & 6 & 40 & 200 & 0 & & & \\
\hline & 1 & 20 & 100 & 0 & $\downarrow$ & $\downarrow$ & 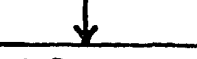 \\
\hline & 8 & 200 & 1,000 & 0 & $\leq \mathrm{BKG}$ & $\leq B K G$ & $\leq B K G$ \\
\hline & & & & & & & \\
\hline & & & $\dot{-}$ & & & & \\
\hline & & & - & - & & & \\
\hline & & & & & & & \\
\hline
\end{tabular}

Fig. B.8. (continued) 
warl West

* metal (Bout orpire)

\begin{tabular}{|c|c|c|c|c|c|c|c|}
\hline row: & blk & $\begin{array}{l}\text { Alpha } \\
\text { probe }\end{array}$ & $\begin{array}{l}\text { Alpha } \\
\text { DPM }\end{array}$ & $\begin{array}{l}\text { Alpha } \\
\text { smear/dpm }\end{array}$ & $\begin{array}{l}\text { Beta- } \\
\text { Gamma } \\
\text { probe }\end{array}$ & $\begin{array}{l}\text { Beta- } \\
\text { Gamma } \\
\text { DPM }\end{array}$ & $\begin{array}{l}\text { Beta- } \\
\text { Gamma } \\
\text { smear/dpm }\end{array}$ \\
\hline \multirow[t]{7}{*}{13} & 1 & 40 & 200 & 0 & $\triangle B K G$ & $\leq B K G$ & $\leq B K G$ \\
\hline & 2 & 40 & 200 & 0 & & & 1 \\
\hline & 3 & 40 & 200 & 0 & & & \\
\hline & 4 & 20 & 100 & 으 & & & \\
\hline & 5 & 20 & 100 & 0 & $\downarrow$ & $\downarrow$ & \\
\hline & 6 & 20 & 100 & 0 & $\leq B K G$ & $\leq B K G$ & 4 \\
\hline & 1 & 2000 & 10,000 & 100 & * 400 & 4,000 & $\leq B K G$ \\
\hline \multirow[t]{8}{*}{14} & 1 & 20 & 100 & 0 & $\leqslant B K G$ & $\leq B K G$ & $\uparrow$ \\
\hline & 2 & 0 & 0 & 50 & 5 & 1 & \\
\hline & 3 & 100 & $500^{\circ}$ & 0 & $\leq B K G$ & $\leq \Delta K G$ & \\
\hline & 4 & 0 & 0 & 50 & 50 & 500 & \\
\hline & 5 & 20 & 100 & 0 & $\leq B K G$ & $\leq B K G$ & \\
\hline & 6 & 20 & 100 & 0 & & $i$ & \\
\hline & 7 & 50 & 250 & 0 & $\leq B K G$ & $\leq B K G$ & \\
\hline & 8 & 3,000 & 15,000 & 200 & 550 & 5,500 & \\
\hline \multirow[t]{7}{*}{15} & 1 & 0 & 0 & 0 & $\leq B K G$ & $\triangle B K G$ & \\
\hline & 2 & 20 & 100 & 0 & & 1 & \\
\hline & 3 & 20 & 100 & 50 & & & \\
\hline & 4 & 50 & 250 & 0 & & & \\
\hline & 5 & 50 & 250 & 0 & $t$ & $\downarrow$ & \\
\hline & 6 & 20 & 100 & 50 & $\leqslant B K G$ & $\leq B K G$ & \\
\hline & 7 & 2,000 & 10,000 & 50 & 500 & 5,000 & \\
\hline \multirow[t]{12}{*}{16} & 1 & 0 & 0 & 0 & $\leqslant 8 K G$ & $\leq B K G$ & \\
\hline & 2 & 0 & 0 & 0 & & & \\
\hline & 3 & 0 & 0 & 0 & 1 & & \\
\hline & 4 & 50 & 250 & 0 & & & \\
\hline & 5 & 0 & 0 & 0 & & & \\
\hline & 6 & 300 & 1,500 & 0 & $\sqrt{2}$ & $\downarrow$ & \\
\hline & 1 & 250 & 1250 & 0 & $\leq B K G$ & $\leq B K G$ & $\downarrow$ \\
\hline & 8 & 1,000 & 5,000 & 50 & 200 & 2,000 & $\leq B K G$ \\
\hline & & & & & & & \\
\hline & & & F & & & & \\
\hline & & & & & & & \\
\hline & & & & & & & \\
\hline
\end{tabular}

Fig. B8. (continued) 
waLL WEST

* metal (bolt or pipe)

\begin{tabular}{|c|c|c|c|c|c|c|c|}
\hline row: & blkt & $\begin{array}{l}\text { Alpha } \\
\text { probe }\end{array}$ & $\begin{array}{l}\text { Alpha } \\
\text { DPM }\end{array}$ & $\begin{array}{l}\text { Alpha } \\
\text { smear/dpm }\end{array}$ & $\begin{array}{l}\text { Beta- } \\
\text { Gamma } \\
\text { probe }\end{array}$ & $\begin{array}{l}\text { Beta- } \\
\text { Gamma } \\
\text { DPM }\end{array}$ & $\begin{array}{l}\text { Beta- } \\
\text { Gamma } \\
\text { smear/dpm }\end{array}$ \\
\hline \multirow[t]{7}{*}{17} & 1 & 0 & 0 & 0 & 200 & 2000 & $\leq B K G$ \\
\hline & 2 & 50 & 250 & 0 & $\leq B K G$ & $\leqslant B K G$ & 1 \\
\hline & 3 & 50 & 250 & 0 & $\pi$ & T & \\
\hline & 4 & 0 & 0 & 0 & & & \\
\hline & 5 & 0 & 0 & 0 & & & \\
\hline & 6 & 100 & 500 & 0 & & & \\
\hline & 7 & 1000 & 5,000 & 50 & & & \\
\hline \multirow[t]{8}{*}{18} & 1 & 0 & 0 & 0 & & & \\
\hline & 2 & 0 & 0 & 0 & & & \\
\hline & 3 & 0 & 0 & 0 & & & \\
\hline & 4 & 100 & 500 & 0 & & & \\
\hline & 5 & 0 & 0 & 0 & $\downarrow$ & + & \\
\hline & 6 & 50 & 250 & 0 & $E B K L$ & $\leq B K G$ & $\downarrow$ \\
\hline & 7 & 50 & 250 & 0 & 50 & 500 & $\leq B K G$ \\
\hline & 8 & 800 & 4,000 & 200 & 100 & 1000 & $\leq B \times G$ \\
\hline \multirow[t]{7}{*}{19} & 1 & 20 & 100 & 0 & $\leq B K G$ & $\leqslant B K G$ & \\
\hline & 2 & 20 & 100 & 0 & $\uparrow$ & T & \\
\hline & 3 & 20 & 100 & 0 & & & \\
\hline & 4 & 20 & 100 & 0 & & & \\
\hline & 5 & 20 & 100 & 0 & & & \\
\hline & 6 & 80 & 400 & 0 & & & \\
\hline & 7 & 50 & 250 & 0 & & & \\
\hline \multirow[t]{8}{*}{20} & 1 & 20 & 100 & 0 & & & \\
\hline & 2 & 0040 & 200 & 0 & & & \\
\hline & 3 & 20 & 100 & 0 & & & \\
\hline & 4 & 20 & 100 & 0 & & & \\
\hline & 5 & 40 & 200 & 0 & & & \\
\hline & 6 & 40 & 200 & 0 & $\downarrow$ & $\downarrow$ & \\
\hline & 7 & 20 & 100 & 0 & $\leq B K G$ & $-B K G$ & $\psi$ \\
\hline & 8 & 40 & 200 & 0 & 100 & 1000 & $\angle B \cap C$ \\
\hline & & & & & & & \\
\hline & & & & & & & \\
\hline & & & & & & & \\
\hline & & & & & & & \\
\hline
\end{tabular}

Fig. B.8 (continued) 
wall West

* metal (Bolt ol ripe)

\begin{tabular}{|c|c|c|c|c|c|c|c|c|}
\hline row & blk & $\begin{array}{l}\text { Alpha } \\
\text { probe }\end{array}$ & $\begin{array}{l}\text { Alpha } \\
\text { DPM }\end{array}$ & $\begin{array}{l}\text { Alpha } \\
\text { smear/dpm }\end{array}$ & $\begin{array}{l}\text { Beta- } \\
\text { Gamma } \\
\text { probe }\end{array}$ & $\begin{array}{l}\text { Beta- } \\
\text { Gamma } \\
\text { DPM } \\
\end{array}$ & $\begin{array}{l}\text { Beta- } \\
\text { Gamma } \\
\text { smear/dpm }\end{array}$ & \\
\hline \multirow[t]{7}{*}{21} & 1 & 20 & 100 & 0 & $\leq B \times 4$ & $\leq B K G$ & $\leq B K G$ & \\
\hline & 2 & 20 & 100 & 0 & 1 & 不 & $\pi$ & \\
\hline & 3 & 20 & 100 & 0 & & & & \\
\hline & 4 & $2 c$ & 100 & 0 & & & & \\
\hline & 5 & 20 & 100 & 0 & & & & \\
\hline & 6 & 20 & 100 & 0 & 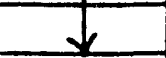 & $\downarrow$ & & \\
\hline & 7 & 100 & 500 & 0 & 50 & 500 & & \\
\hline \multirow[t]{8}{*}{22} & 1 & 40 & 200 & 0 & $\leq B K G$ & $\Sigma B K G$ & & \\
\hline & 2 & 20 & 100 & 0 & 1 & 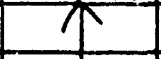 & & \\
\hline & 3 & 40 & 200 & 0 & & & & \\
\hline & 4 & 40 & 200 & 0 & $\downarrow$ & $\downarrow$ & & \\
\hline & 5 & 40 & 200 & 0 & * 50 & 500 & & \\
\hline & 6 & 40 & 200 & 300 & $\leq B \times G$ & $\leqslant B K G$ & & \\
\hline & 7 & 100 & 500 & 50 & $\leq B K G$ & $\leqslant B K G$ & & \\
\hline & 8 & 40 & 200 & 0 & 50 & 500 & & \\
\hline \multirow{7}{*}{23} & 1 & 30 & 150 & 0 & $\leq B K G$ & $\angle B K G$ & & \\
\hline & 2 & 40 & 200 & 0 & $\uparrow$ & 不 & & \\
\hline & 3 & 30 & 150 & 0 & & & & \\
\hline & 4 & 20 & 100 & 0 & $x$ & & & \\
\hline & 5 & 0 & 0 & 0 & 50 & 500 & & \\
\hline & 6 & 20 & 100 & 0 & $\leq B K G$ & $\leq B K G$ & & \\
\hline & 7 & $* 200$ & 1000 & 0 & ${ }^{*} 50$ & 500 & & \\
\hline \multirow[t]{8}{*}{24} & 1 & 30 & 150 & 0 & $\leqslant B K G$ & $\leq B k G$ & & \\
\hline & 2 & 30 & 150 & 0 & $\leq B K G$ & $\leq 8 k 4$ & & \\
\hline & 3 & 10 & 50 & 0 & 50 & 500 & & \\
\hline & 4 & 20 & 100 & 0 & $\leq B K G$ & $\leq 6 \times 6$ & & \\
\hline & 5 & 20 & 100 & 0 & 尔 & 不 & & \\
\hline & 6 & 10 & 50 & 0 & $\sqrt{2}$ & $\sqrt{2}$ & & \\
\hline & 7 & 20 & 100 & 0 & 550 & 500 & $\downarrow$ & \\
\hline & 8 & *80 & 400 & 0 & $x_{50}$ & 500 & $\leq B K G$ & \\
\hline & & & & & & & & \\
\hline & & & . & & & & & \\
\hline & & & & & & & & \\
\hline & & & & & & & & \\
\hline
\end{tabular}

Fig. B.8. (continued) 
wazL WEST

* metal (Bolt or pipe)

\begin{tabular}{|c|c|c|c|c|c|c|c|}
\hline row: & blk: & $\begin{array}{l}\text { Alpha } \\
\text { probe }\end{array}$ & $\begin{array}{l}\text { Alpha } \\
\text { DPM }\end{array}$ & $\begin{array}{l}\text { Alpha } \\
\text { smear/dpm }\end{array}$ & $\begin{array}{l}\text { Beta- } \\
\text { Gamma } \\
\text { probe }\end{array}$ & $\begin{array}{l}\text { Beta- } \\
\text { Gamma } \\
\text { DPM } \\
\end{array}$ & $\begin{array}{l}\text { Beta- } \\
\text { Gamma } \\
\text { smear/dpm }\end{array}$ \\
\hline \multirow[t]{7}{*}{25} & 1 & 80 & 400 & 0 & $\leq B K G$ & $\leq B K G$ & $\leq B K G$ \\
\hline & 2 & 800 & 4000 & 100 & 50 & 500 & 1 \\
\hline & 3 & 20 & 100 & 0 & $\leq B \times 4$ & $\equiv B K G$ & \\
\hline & 4 & 40 & 200 & 0 & 50 & 500 & \\
\hline & 5 & 150 & 750 & 0 & 50 & 500 & $\downarrow$ \\
\hline & 6 & 320 & 1600 & 0 & 100 & 1000 & $\leq B K G$ \\
\hline & 7 & 50 & 250 & 0 & 0 & 0 & $\leq B K G$ \\
\hline & & & & & & & \\
\hline & & & & & & 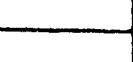 & \\
\hline & & & & & & & \\
\hline & & & & & & & \\
\hline & & & & & & & \\
\hline & & & & & & & \\
\hline & & & & & & & \\
\hline & & & & & & & \\
\hline & & & & & & & \\
\hline & & & & & & & \\
\hline & & & & & & & \\
\hline & & & & & & & \\
\hline & & & & & & & \\
\hline & & & & & & & \\
\hline & & & & & & & \\
\hline & & & & & & & \\
\hline & & & & & & & \\
\hline & & & & & & & \\
\hline & & & & & & & - \\
\hline & & & & & & & \\
\hline & & & & & & & \\
\hline & & & & & & & \\
\hline & & & & & & & \\
\hline & & & & & & & \\
\hline & & & & & & & \\
\hline & & & & & & & \\
\hline & & & & & & & \\
\hline
\end{tabular}

Fie. B.8. (continued) 


\section{RADIOLOGICAL SURVEY REPORT}

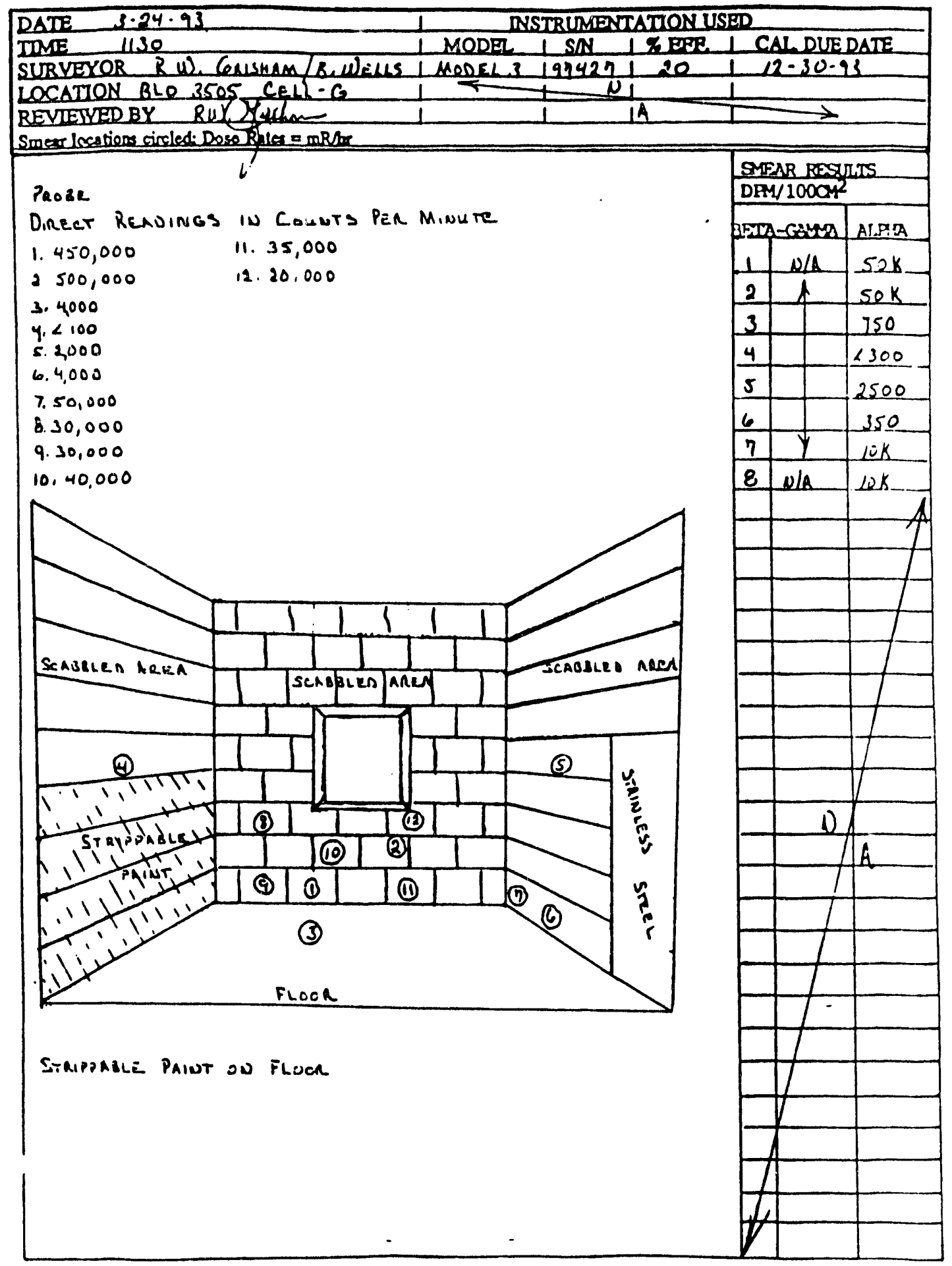

Fig. B.9. Radiological survey report, Mar. 24, 1993. 
Coris Emipls

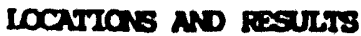

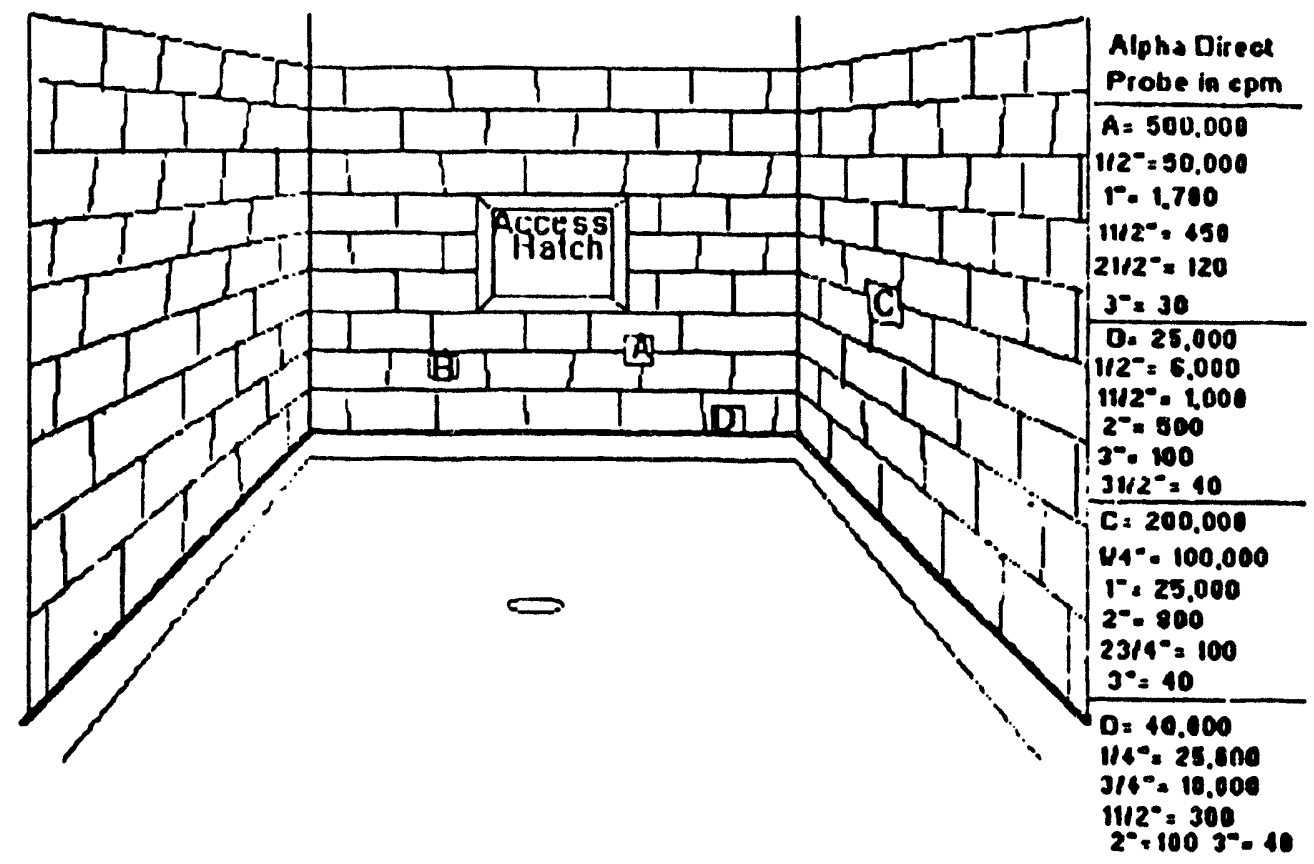

Fig B.10 Core anmple bocations and results. 


\section{RADIOLOGICAL SURVEY REPORT}

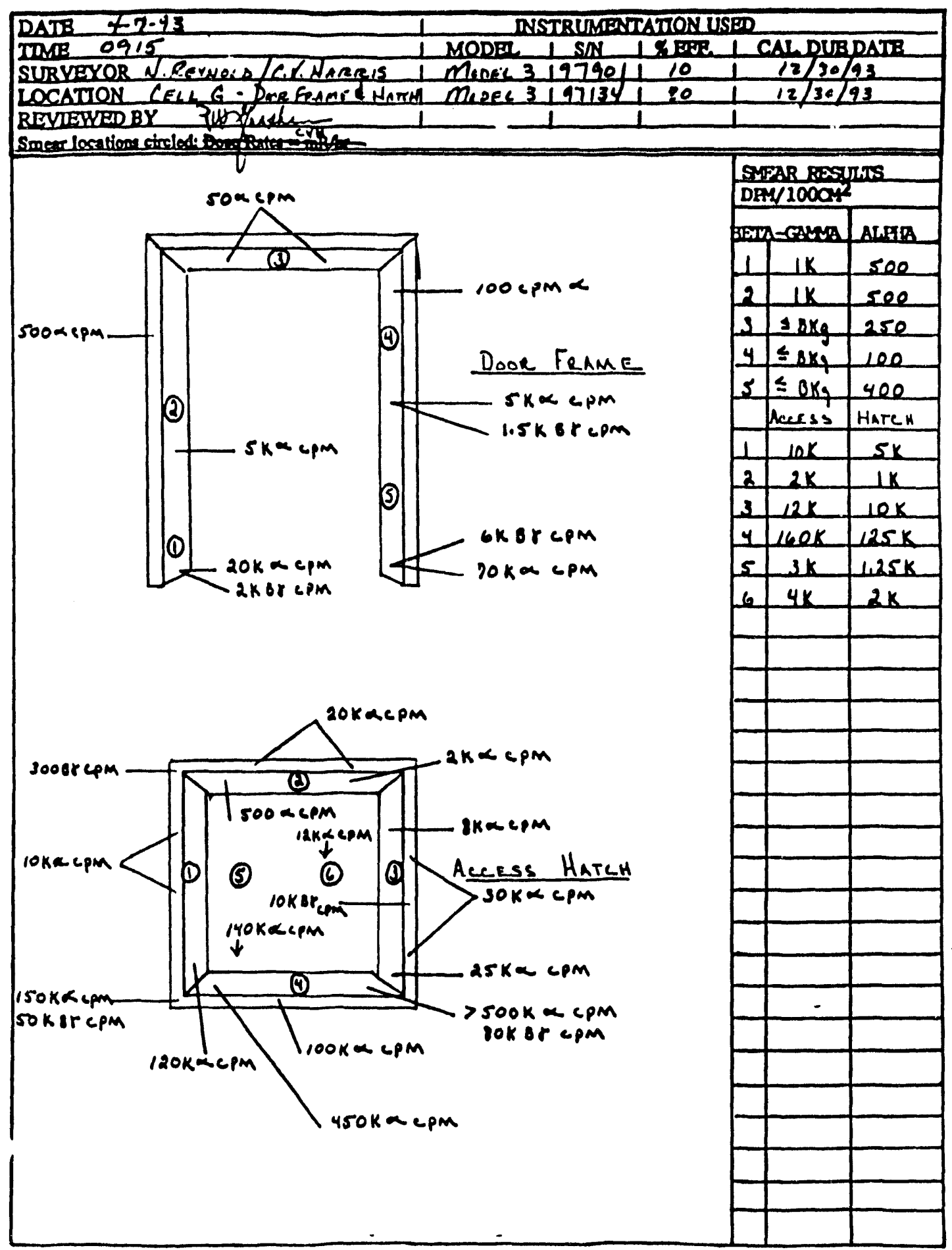

FOFM 124

Fig. B.11. Radiological survey report, April 7, 1993. 
PAGS 1 of 4

NORTH WALL CONTAMINATION LEVELS

Aloha contamination dom/direct probe i ixed

POST 1/4" REMOVEL POST 3/4" REMOVEL ALPHA SMEARABLE

rown block" alpha dpm

a loha dpm

(1)

(2)

(3)

(4)

(5)

(6)

(7)

$$
\begin{array}{r}
5,000 \\
50,000 \\
25,000 \\
25,000 \\
100,000 \\
25,000 \\
50,000 \\
15,000 \\
15,000 \\
5,000 \\
150,000 \\
100,000 \\
50,000 \\
5,000 \\
25,000 \\
1,000 \\
3,000 \\
100,000 \\
20,000 \\
50,000 \\
3,000 \\
5,000 \\
2,000 \\
100,000 \\
1,000 \\
5,000 \\
1,000 \\
5,000 \\
1,000 \\
50,000 \\
20,000 \\
5,000 \\
5,000 \\
1,000 \\
5,000 \\
5,000 \\
25,000 \\
1,000 \\
500 \\
500 \\
10,000 \\
3,000 \\
500 \\
500 \\
\end{array}
$$

$\mathrm{dpm} / 100 \mathrm{~cm} \mathrm{~m}^{2}$

< 300

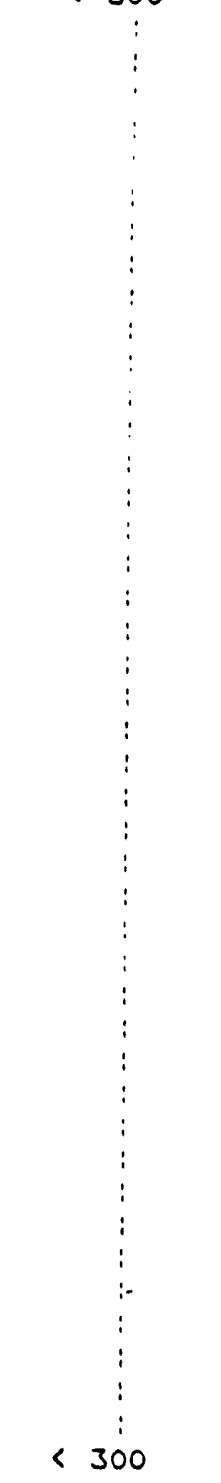

Fis. B.12 North wall contamination levels. 


\section{B-47}

PACE 2 of 4

NORTH WALL CONTAMINATION LEVELS

Alpha contamination dem/direct probe fixed

POST 1/4" REMOVEL POST 3/4" REMOVEL ALPHA SMEARABLE

row"

block alpha dom

alpha dpm

$d p \sin / 100 \mathrm{em} m^{2}$

(8)

3,000

6,000

6,500

175,000

500,000

80,000

(9)

30,000

85,000

45,000

(10)

125,000

500
500
1,000
5,000
5,000
3,000
4,000
3,000
5,000
1,000

$<300$

(1)

$:$

$:$

$:$

$:$

$<300$

Fig. B.12 (continued) 


\section{B-48}

PACE 3 of 4

EAST WALL CONTAMINATION LEVELS

Alpha contamination dpm/direct probe fised

POST 1/4" REMOVEL POST 3/4" REMOVEL ALPHA SMEARABLE

row block" alpha dpm

a lpha dpm

$0 p \mathrm{~m} / 100 \mathrm{~cm}^{2}$

(1)

225,000

30,000

10,000

25,000

12,500

350,000

350,000

3,500

12,500

150,000

850,000

300,000

17,500

10,000

100,000

200,000

60,000

10,000

(5)

150,000

250,000

10,000

35,000

60,000

50,000

16,500

75,000

90,000

7,000

45,000

2,000

500

1,000

50,000

25,000

4,000

20,000

25,000

150,000

1,000

2,000

4,000

20,000

15,000

$<300$

1,000

10,000

5,000

1,000

15,000

15,000

4,000

5,000

5,000

5,000

2,000

$<300$

2,000

2,000

$<300$

$$
10,000
$$

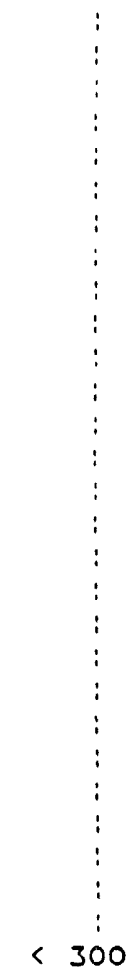

Fig. B.13. Esat wall contamination levels. 
PAeE 4 of 4

WEST WALL CONTAMINATION LEVELS

Alpha contamination dpm/direct probe fixed

POST 1/4" REMOVEL POST 3/4" REMOVEL ALPHA SMEARABLE

\begin{tabular}{|c|c|c|c|c|c|}
\hline rown & block* & a lpha dpm & a lpha opm & apm/ & $1100 c$ \\
\hline \multirow[t]{4}{*}{ (1) } & 3 & 2,500 & 5,000 & $<$ & 300 \\
\hline & 4 & 100,000 & 2,000 & $<$ & 300 \\
\hline & 5 & 20,000 & 1,500 & $<$ & 300 \\
\hline & 6 & 15,000 & 5,000 & $<$ & 300 \\
\hline \multirow{6}{*}{$\begin{array}{l}\text { P spe } \\
(2)\end{array}$} & --7 & 125,000 & 25,000 & 15, &, 000 \\
\hline & 4 & 12,500 & 5.000 & $<$ & 300 \\
\hline & 5 & 50,000 & 2,000 & $<$ & 300 \\
\hline & 6 & 10,000 & 2,000 & $<$ & 300 \\
\hline & 7 & 25,000 & 5,000 & $<$ & 300 \\
\hline & $\mathbf{B}$ & 17,500 & 10,000 & $<$ & 300 \\
\hline \multirow[t]{3}{*}{ (3) } & 5 & 15,000 & 2,000 & $<$ & 300 \\
\hline & 6 & 30,000 & 5,000 & $<$ & 300 \\
\hline & 7 & 25,000 & 5,000 & $<$ & 300 \\
\hline \multirow[t]{4}{*}{ (4) } & 5 & 6,000 & 5,000 & $<$ & 300 \\
\hline & 6 & 3,000 & 2,000 & $<$ & 300 \\
\hline & 7 & 11,000 & 500 & $<$ & 300 \\
\hline & 8 & 12,500 & 5,000 & $<$ & 300 \\
\hline (5) & 5 & 4,000 & 5,000 & $<$ & 300 \\
\hline & 6 & 10,000 & 300 & $<$ & 300 \\
\hline & 7 & 3,500 & 1,500 & $<$ & 300 \\
\hline (6) & 6 & 5,000 & 1,000 & $<$ & 300 \\
\hline & 7 & 3,000 & 2,000 & $<$ & 300 \\
\hline & 8 & 3,250 & 1,000 & $<$ & 300 \\
\hline (7) & 7 & 4,000 & 5,000 & $<$ & 300 \\
\hline
\end{tabular}

Fig. B.14. Weat wall contamination bovek. 


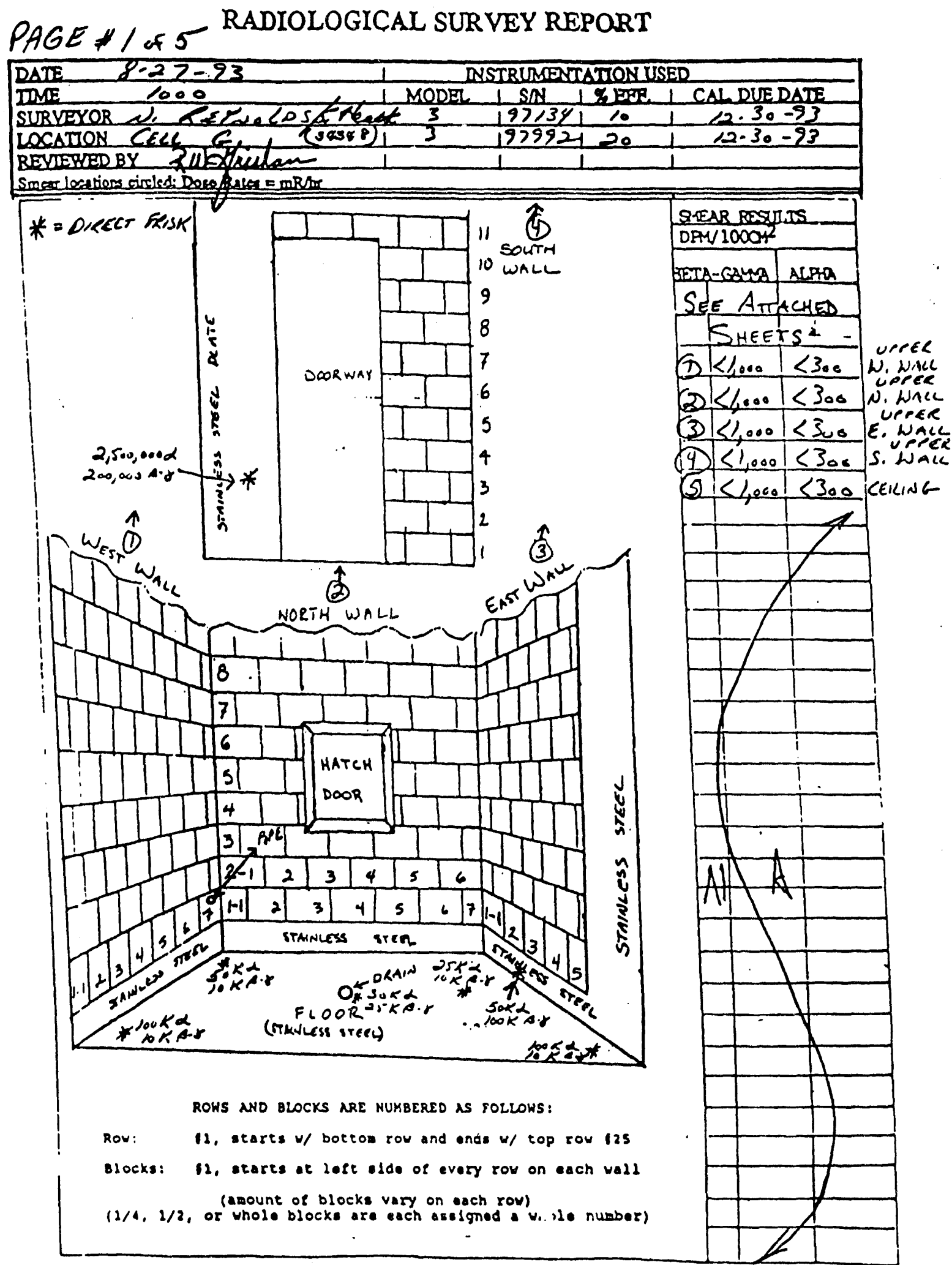

Fig. B.15. Radiological survey report, Aug 27, 1993. 
wALL NOKIA GAGE $\frac{\text { WALL }}{2}$ of 5

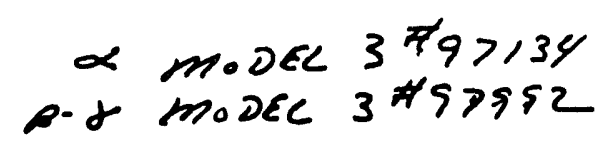

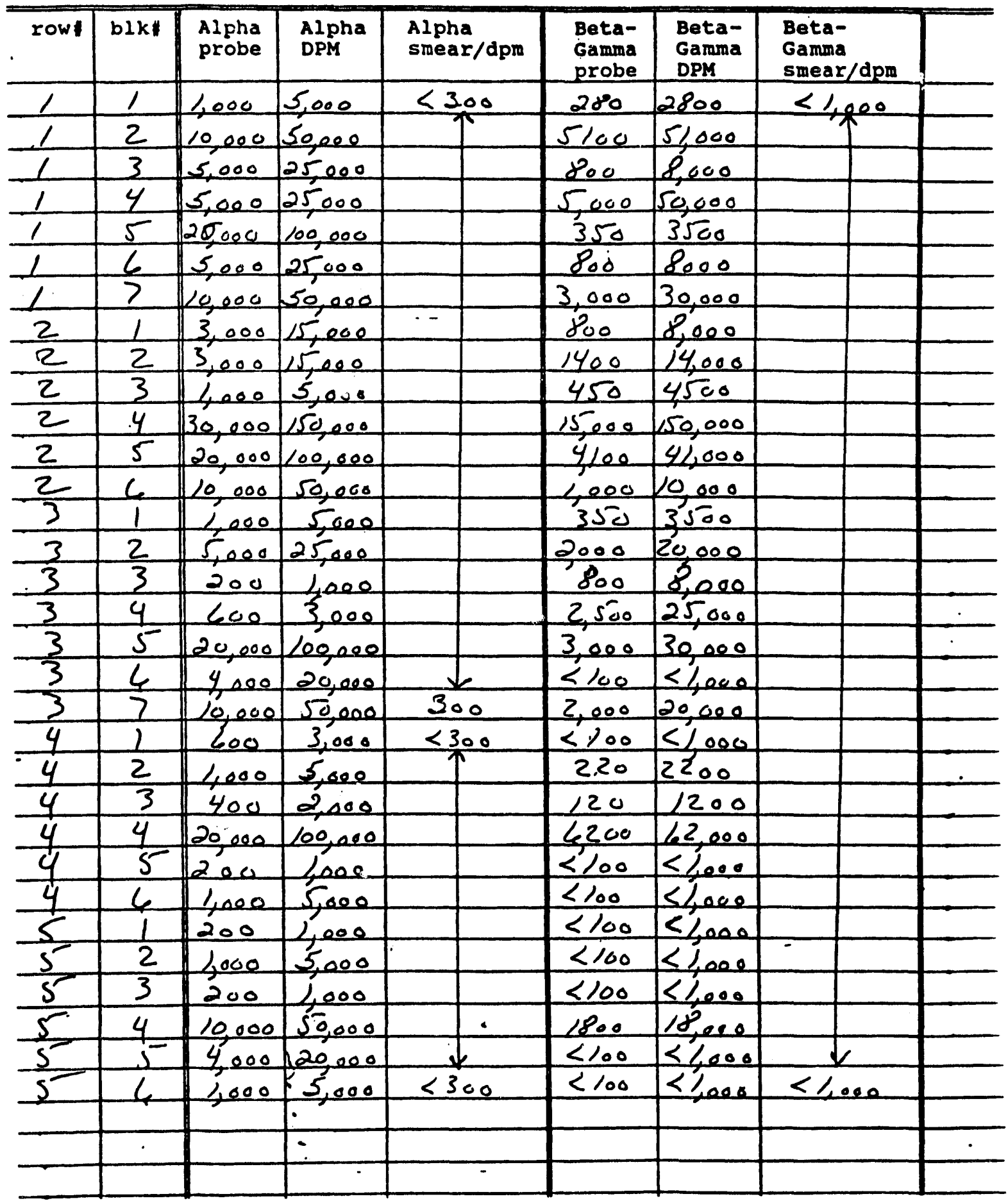

Fig. B.15. (continued) 
WALL NORTH WALC

$$
\begin{aligned}
& \alpha \text { modec } 3 \text { F } 7 / 3 \\
& \text { p.d madec } 3 \text { F>99. }
\end{aligned}
$$

\begin{tabular}{|c|c|c|c|c|c|c|c|c|}
\hline row 1 & blk & $\begin{array}{l}\text { Alpha } \\
\text { probe }\end{array}$ & $\begin{array}{l}\text { Alpha } \\
\text { DPM }\end{array}$ & $\begin{array}{l}\text { Alpha } \\
\text { smear/dpm }\end{array}$ & $\begin{array}{l}\text { Beta- } \\
\text { Gamma } \\
\text { probe }\end{array}$ & $\begin{array}{l}\text { Beta- } \\
\text { Gamma } \\
\text { DPM }\end{array}$ & $\begin{array}{l}\text { Beta- } \\
\text { Gamma } \\
\text { smear/dpm }\end{array}$ & \\
\hline 6 & 1 & 1,000 & 5,0 & $\leq 300$ & $\leq 100$ & $</, 000$ & $<1,000$ & \\
\hline 4 & 2 & 200 & 4, & 个 & $\leq 100$ & $<1,000$ & & \\
\hline 4 & 3 & 1,000 & 5 & & $<100$ & 5,000 & & \\
\hline 4 & 4 & 1,000 & 00 & & 1,000 & 10,600 & & \\
\hline 4 & 5 & 5,000 & 25,8 & & $\leq 100$ & $<$ hoen & & \\
\hline 4 & 6 & 200 & 1,000 & & & 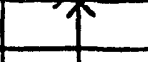 & & \\
\hline 7 & 1 & 100 & 500 & & & & & \\
\hline 7 & 2 & 100 & 500 & & & & & \\
\hline$?$ & 3 & 100 & 500 & & $\sqrt{2}$ & $\downarrow$ & & \\
\hline 7 & 4 & 100 & 500 & & $\leq 100$ & Ll, ease & & \\
\hline 7 & .5 & 2,000 & 10,000 & & 6,000 & 60000 & & \\
\hline 7 & 6 & 600 & 3,000 & & $</ 00$ & $</, 000$ & & \\
\hline 7 & 2 & 100 & 500 & & 200 & 2,000 & & \\
\hline 8 & 1 & 100 & 500 & & $\leq 100$ & $</, 000$ & & \\
\hline 8 & 2 & 100 & 500 & & $<100$ & Shen & & \\
\hline 8 & 3 & 200 & 1,0e0 & & 200 & 2000 & & \\
\hline 8 & 4 & م0مر & S, & & 1,000 & 10,000 & & \\
\hline 8 & 5 & ممصرا & 5,000 & & 2,000 & 20,000 & & \\
\hline 8 & $c$ & 600 & 3,000 & & 1,000 & 10 ,ove & & \\
\hline 9 & 5 & 800 & 4,000 & & heoe & 10,000 & & \\
\hline 9 & 6 & 600 & 3,000 & 1 & 2000 & 20,000 & & \\
\hline 9 & 7 & Le0 & 5,006 & $\downarrow$ & 2,000 & 20,000 & $\psi$ & \\
\hline 10 & 5 & 200 & مهري & $\angle 300$ & 1,000 & 10,000 & $<1,000$ & \\
\hline & & & & & & & & \\
\hline & & & & & & & & \\
\hline & & & & & & & & \\
\hline & & & & & & & - & \\
\hline & & & & & & & & \\
\hline & & & & & & & & \\
\hline & & & & & & & & \\
\hline & & & & & & & & \\
\hline & & & $\dot{-}$ & & & & & \\
\hline & & & 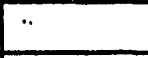 & & & & & \\
\hline & & & - & - & & & & \\
\hline & & & & & & & & \\
\hline
\end{tabular}

Fig. B.15. (continued) 
WALL WEST WALC $\alpha$ modec $3 * 97134$
B. modec $3 * 97992$ Page 4 of 5

\begin{tabular}{|c|c|c|c|c|c|c|c|c|}
\hline row: & blkt & $\begin{array}{l}\text { Alpha } \\
\text { probe }\end{array}$ & $\begin{array}{l}\text { Alpha } \\
\text { DPM }\end{array}$ & $\begin{array}{l}\text { Alpha } \\
\text { smear/dpm }\end{array}$ & $\begin{array}{l}\text { Beta- } \\
\text { Gamma } \\
\text { probe }\end{array}$ & $\begin{array}{l}\text { Beta- } \\
\text { Gamma } \\
\text { DPM } \\
\end{array}$ & $\begin{array}{l}\text { Beta- } \\
\text { Gamma } \\
\text { smear/dpm }\end{array}$ & \\
\hline 1 & 3 & $\angle, 000$ & 5,000 & $\leq 300$ & $<100$ & $\leq$ hoee & $</$, & \\
\hline 1 & 4 & Yoo & 2,000 & $\uparrow$ & T & & $\uparrow$ & \\
\hline 1 & 5 & 300 & $\angle 500$ & 1 & $\sqrt{k}$ & $\downarrow$ & 1 & \\
\hline 1 & $\zeta$ & Leee & 5,000 & $\leq 300$ & $<100$ & $<1,000$ & معم, كا & \\
\hline 1 & 7 & 5,000 & 25,000 & 15,000 & 20,000 & 200,000 & 1000 & pipe \\
\hline 2 & 4 & 1,000 & 5,000 & $\angle 300$ & 5100 & $\leq 1$ gea & 1 & \\
\hline 2 & 5 & 400 & 2,000 & 7 & & & & \\
\hline 2 & $\zeta$ & 400 & 2,000 & & & & & \\
\hline 2 & 2 & 1,000 & 5,000 & & & & & \\
\hline 2 & 8 & 2,000 & 10,000 & & & & & \\
\hline 3 & .5 & 400 & 2,000 & & & & & \\
\hline 3 & 6 & 1,000 & 5,000 & & & & & \\
\hline 3 & 7 & 4,000 & 5,000 & & & & & \\
\hline 4 & 5 & 1,000 & 5,000 & & & & & \\
\hline 4 & $\zeta$ & 400 & 2,000 & & & & & \\
\hline 4 & 7 & 100 & 500 & & & & & \\
\hline 4 & 8 & 1000 & 5,000 & & & & & \\
\hline 5 & 5 & 1,000 & 5,000 & & & & & \\
\hline 5 & 6 & 60 & 300 & & & & & \\
\hline 5 & 2 & 300 & 1500 & & & & & \\
\hline 6 & 6 & 200 & 1,000 & & & & & \\
\hline 6 & 7 & Yeo & 2,000 & & & & & \\
\hline 4 & 8 & 200 & 2,000 & 1 & $\downarrow$ & $x$ & $x$ & \\
\hline 7 & 7 & 1,000 & 5,000 & $\angle 300$ & $<100$ & $\langle/, 000$ & $\angle, 000$ & \\
\hline Elod & $R$ & 50,000 & 50,000 & .750 & 1000 & 10,000 & 1,000 & \\
\hline$t$ & & 20,000 & مOمومد & 1000 & 1,e0e & 10,000 & 4 & \\
\hline DRA & 2 & 6,000 & 30,000 & 1,000 & 2,500 & 25,000 & - & \\
\hline Elod & $R$ & 5,000 & 25,000 & 250 & t,e0e & 10,000 & & \\
\hline & & 10,000 & so,eod & 250 & 10,000 & 100,000 & & \\
\hline 7 & & 20,000 & 100,000 & 250 & 1,000 & 10,000 & $\checkmark$ & \\
\hline & & & & & & & & \\
\hline & & & & & & & & \\
\hline & & & $\because$ & & & & & \\
\hline & & & & - & & & & \\
\hline 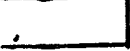 & & & & & & & & \\
\hline
\end{tabular}

Fig. B.15. (continued) 


\begin{tabular}{|c|c|c|c|c|c|c|c|c|}
\hline row & blkt & $\begin{array}{l}\text { Alpha } \\
\text { probe }\end{array}$ & $\begin{array}{l}\text { Alpha } \\
\text { DPM }\end{array}$ & $\begin{array}{l}\text { Alpha } \\
\text { smear/dpr }\end{array}$ & $\begin{array}{l}\text { Beta- } \\
\text { Gamma } \\
\text { probe }\end{array}$ & $\begin{array}{l}\text { Beta- } \\
\text { Gamma } \\
\text { DPM }\end{array}$ & $\begin{array}{l}\text { Beta- } \\
\text { Gamma } \\
\text { smear/dpm }\end{array}$ & \\
\hline 1 & 1 & C,e00 & 30,000 & $<300$ & 1400 & 14 oad & $<1,000$ & \\
\hline 1 & 2 & 2,000 & 10,000 & $\pi$ & 600 & 00 & 争 & \\
\hline 1 & 3 & 100 & 500 & & $\leq / 00$ & 000 & & \\
\hline 2 & 1 & 200 & 1,000 & & $<100$ & 000 & & \\
\hline 2 & 2 & 10,000 & 50,000 & & 2,000 & 20,000 & & \\
\hline 2 & 3 & 5,000 & 25,000 & & 3,000 & 20,000 & & \\
\hline 2 & 4 & Poo & 4000 & & $\leq 100$ & $\leq /, 000$ & & \\
\hline 2 & 5 & 4,000 & 20,000 & & $S / 00$ & $\leq /, 000$ & & \\
\hline 3 & 1 & 5,000 & 25,000 & & 600 & 6000 & & \\
\hline 3 & 2 & 30,000 & 150,000 & & 5,800 & S000 & & \\
\hline 3 & 3 & 200 & 1,e00 & & $\leq 100$ & $\leq$ foee & & \\
\hline 3 & 4 & 400 & 2000 & & $<100$ & $S /, 000$ & & \\
\hline 3 & 5 & 800 & 4,000 & & $\leq 1.0$ & $<, 000$ & & \\
\hline 4 & 1 & 4 ,eoe & 20,000 & & 400 & 4,000 & & \\
\hline 4 & 2 & 3,000 & 15,000 & & $1, \infty$ & 10,000 & & \\
\hline 4 & 3 & $3<<0$ & $<30 c$ & & $\leqslant 100$ & $\leq 4000$ & & \\
\hline 4 & $y$ & 200 & 1,000 & & $</ 00$ & معهر/ & & \\
\hline 5 & 1 & 2000 & 10,000 & & $<100$ & معركS & & \\
\hline 5 & 2 & 1,000 & 5,000 & & 1200 & 12,000 & & \\
\hline$\sqrt{5}$ & 3 & 200 & K,000 & & $\leq 100$ & & & \\
\hline 4 & 1 & 3000 & $s, 000$ & & & & & \\
\hline 4 & 2 & 3,000 & 1000 & & & & & \\
\hline 6 & 3 & Poo & 4000 & & & & & \\
\hline 7 & 1 & 1,000 & 5,000 & & & & & \\
\hline 7 & 2 & 1,000 & $\sqrt{1000}$ & & & & & \\
\hline$\sum$ & 3 & j,oen & 5,000 & & & & & \\
\hline 8 & 1 & Yoe & 2,000 & & & & & \\
\hline 8 & 2 & $<60$ & $<300$ & & & & - & \\
\hline 9 & 1 & 400 & 2,000 & $\sqrt{2}$ & 1 & 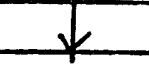 & $x$ & \\
\hline 9 & 2 & 400 & 2,000 & $\leq 300$ & $\leq 100$ & $\leq /, 000$ & $</, 000$ & \\
\hline & & & & & & & & \\
\hline & & & . & & & & & \\
\hline & & & & & & & & \\
\hline & & & & & & & & \\
\hline & & & & & & & & \\
\hline
\end{tabular}

Fig. B.15. (continued) 
Appendix C

\section{LESSONS LEARNED}


The conduct of the MRF Cell G decontamination project provided insight into areas where improvements can be made for future endeavors of a similar nature. Following is a synopsis of lessons learned from this project:

1. One of the original goals of this project was to find a quick mechanism to contract with an established company (by task order arrangement) to perform actual decontamination work. The selection of ATG necessitated the use of DOE Procurement to place the contract. Because of many delays for various reasons, the procurement process took 3.5 years to complete. Obviously, this timeframe was not compatible with established schedules and resulted in milestones continually not being met. Future contracts should be placed with MMES Procurement, where programmatic interests have a greater influence on procurement priorities.

2. Use of a fixed price subcontract posed numerous problems for the type of work performed. The level of decontamination work necessary to achieve desired end-points cannot be accurately assessed beforehand, because the depth of contaminant penetration varied considerably in the cell. Decontamination work tends to encompass a vast amount of unknowns which prevent accurate fixed price astimates. Time delays associated with change notices and modifications to the contract caused schedule delays and milestones to slip. More flexible procurement strategies should be considered for future projects of this nature.

3. The subcontractor needs to provide more time in the period of performance to accomodate the various types of training for its personnel. Considering the scrutiny that this type of work receives, it would also be prudent to factor in additional time for environmental, safety, and health audits and reviews. Both of these items need to be reflected in the subcontractor's bid and schedule.

4. Contaminant penetration into the concrete walls was much greater than expected based on prior characterization efforts. The type of processes used during the operational years, location of process equipment, radioisotopic composition of the contamination, structural composition of the area to be decontaminated, and potential pathways of contaminant migration (grout between concrete blocks) are all factors that should be analyzed to more accurately determine the extent of decontamination effort required. Unless prior characterization took all of the preceding into account, these data should not be heavily relied on as an accurate assessment, but should only be used to provide a general contamination profile of the area. Verification of existing data should be considered during the project planning phase.

5. A major problem during the course of this project was the selection of respiratory protective equipment. Based on the existing contamination levels in Cell G, Radiation Protection stipulated the protection factur for respiratory equipment while performing decontamination operations. Several types of respirators were considered for use but, during the time that contract implementation was attempted, the protection factors accepted by Industrial Hygiene were lowered dramatically. This caused several reevaluations of what the desired respiratory device should be, and the establishment of an acceptable breathing air system ultimately became a time-critical component. Close interaction with Industrial Hygiene and Radiation Protection was necessary to ensure that all administrative and technical requirements were met. 
Appendix D

COST AND SCHEDULE SUMMARY 


\section{D-3}

The total cost of the Cell $G$ decontamination project is provided below. It is a combination of expenses incurred by ATG and MMES.

\section{Cell Decontaminntion (ATG)}

Operating personnel wages, benefits, $\$ \$ 324,461$

etc.

Supplies

$\$ 22,864$

Equipment rental

$\$ 15,137$

Subtotal

$\$ 362,463$

Cell Docontamination Support (MMES)

Support personnel wages

$\$ 151,477$

Supplies (includes respirators)

$\$ 41,507$

Sample analyses

$\$ 12,776$

Health Physics oversight

$\$ 28,411$

Project management

$\$ 71,933$

Subtotal

$\$ 306,104$

Grand Total

$\$ 668,567$ 


\section{D-5}

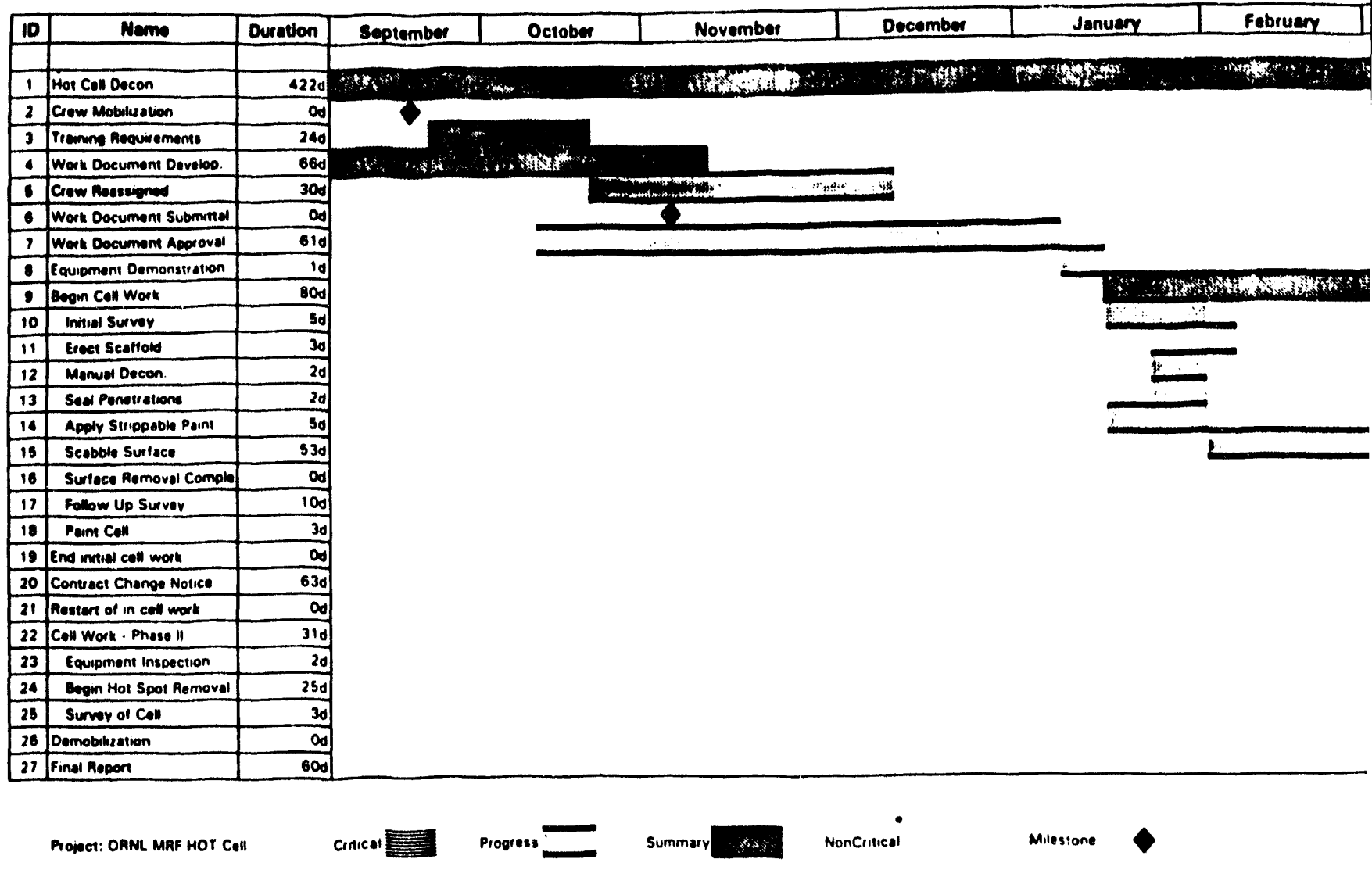

Fig. D.1. MRF Cell C 


\begin{tabular}{|l|l|l|l|l|l|l|l|}
\hline Merch & April & May & Juno & Ju'y & Auguet & September & October \\
\hline
\end{tabular}

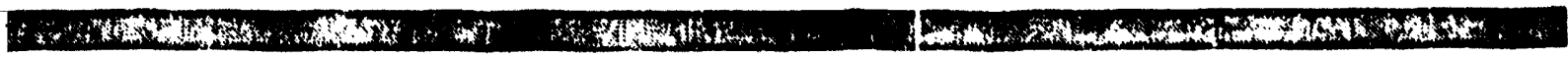

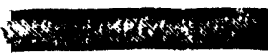

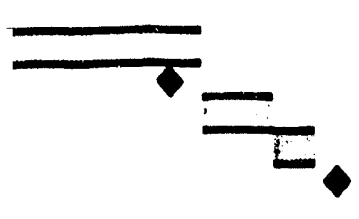

project schedule. 


\section{DISTRIBUTION}

1. H. L. Boston

2. T. W. Burwinkle

3. K. Constant

4. K. W. Haff

5. O. W. Hale

6. J. H. Hooyman

7. M. A. Johnson

8. L. L. Kaiser

9. K. E. Lott

10. G. J. Mandry

11-13. D. M. Matteo

14-15. P. T. Owen

16. C. E. Pepper

17. H. D. Renner

18. P. A. Schrandt

19. P. S. Wood

20-22. ORNL ER Document Management Center

23-25. Central ER Document Management Center

26. Laboratory Records Department

27. ORNL Patent Section

28. Central Research Library

29. Office of Assistant Manager for Energy Research and Development, DOE Oak Ridge Operations Office, P.O. Box 2001, Oak Ridge, TN 37831-8600

30-31. Allied Technology Group, 44075 Freemont Boulevard, Freemont, CA 94538

32. G. R. Hudson, DOE Oak Ridge Operations Office, P.O. Box 2001, Oak Ridge, TN 37831-8541

33. M. R. Jugan, DOE Oak Ridge Operations Office, Information Resource Center, P.O. Box 2001, Oak Ridge, TN 37831-8541

34. R. C. Sleeman, DOE Oak Ridge Operations Office, P.O. Box 2001, Oak Ridge, TN 37831-8541

35. J. T. Sweeney, DOE Oak Ridge Operations Office, P.O. Box 2001, Oak Ridge, TN 37831-8541

36. W. Snedakar, EBASCO Services, 111 Union Valley Road, Oak Ridge, TN 38730

37-38. Office of Scientific and Technical Information, P.O. Box 62, Oak Ridge, TN 37831 

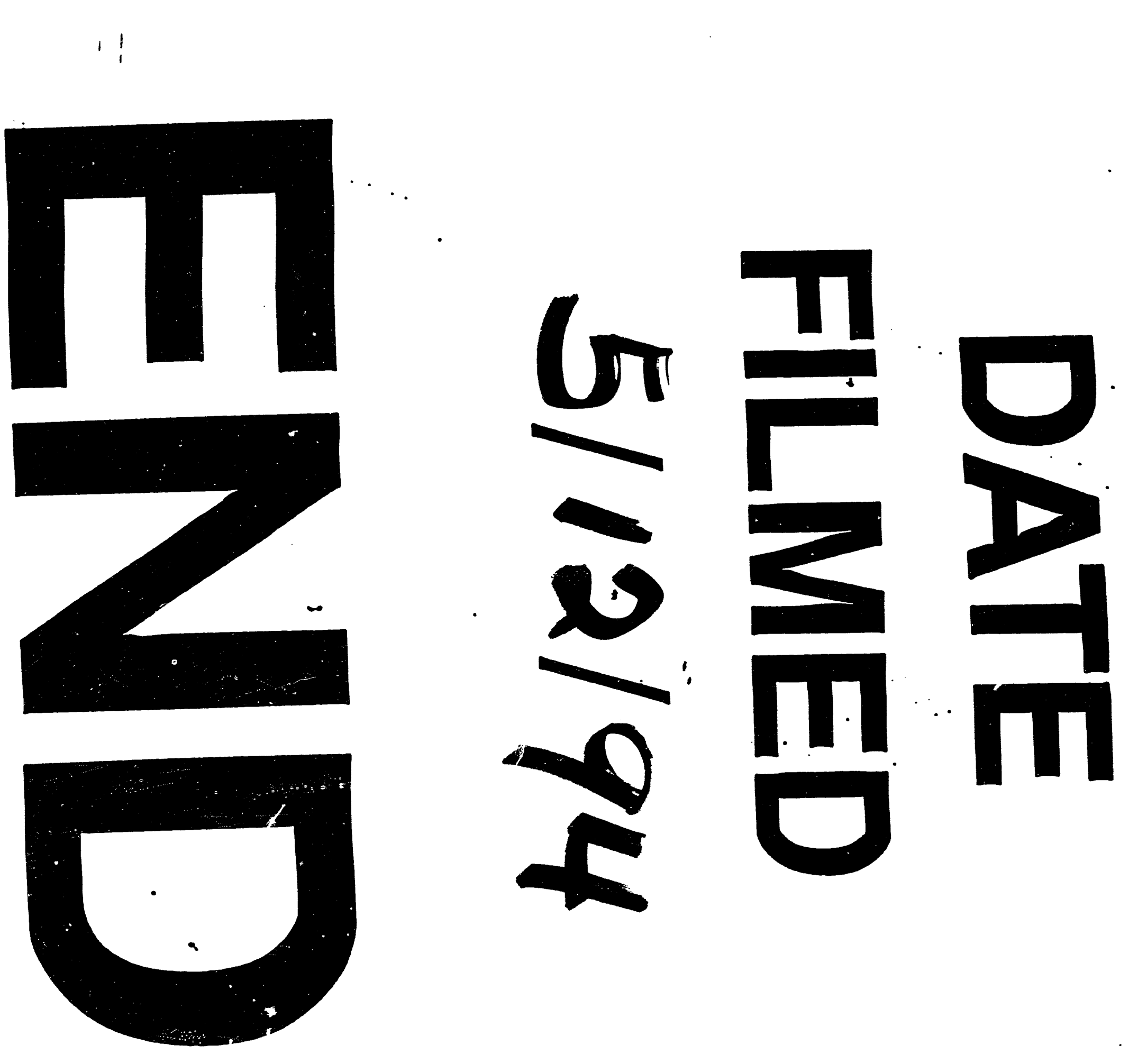